\title{
ANÁLISE GENÉTICA DA RESISTÊNCIA À ANTRACNOSE FOLIAR EM MILHO
}

VIVIANE FERREIRA REZENDE

Tese apresentada à Escola Superior de Agricultura "Luiz de Queiroz", Universidade de São Paulo, para obtenção do título de Doutor em Agronomia, Área de Concentração: Genética e Melhoramento de Plantas.

\author{
P I R A C I C A B A \\ Estado de São Paulo - Brasil \\ Janeiro - 2004
}




\section{ANÁLISE GENÉTICA DA RESISTÊNCIA À ANTRACNOSE FOLIAR EM MILHO}

\section{VIVIANE FERREIRA REZENDE}

Engenheiro Agronônomo

Orientador: Prof. Dr. Luis Eduardo Aranha Camargo

Tese apresentada à Escola Superior de Agricultura "Luiz de Queiroz", Universidade de São Paulo, para obtenção do título de Doutor em Agronomia, Área de Concentração: Genética e Melhoramento de Plantas.

\footnotetext{
P I R A C I C A B A

Estado de São Paulo - Brasil

Janeiro - 2004
} 
Dados Internacionais de Catalogacão na Publicacão (CIP) DIVISÃO DE BIBLIOTECA E DOCUMENTAÇÃO - ESALQ/USP

Rezende, Viviane Ferreira

Análise genética da resistência à antracnose foliar em milho / Viviane Ferreira Rezende. - Piracicaba, 2004.

103 p. : il.

Tese (doutorado) - Escola Superior de Agricultura Luiz de Queiroz, 2004

Bibliografia.

1. Antracnose 2. Controle genético 4. Mapeamento genético 5. Marcador molecular (identificação) 6 . Milho 7 . Resistência à doença 8 . Resistência genética vegetal I. Título

CDD 633.15

"Permitida a cópia total ou parcial deste documento, desde que citada a fonte - $\mathrm{O}$ autor" 
Aos meus pais, José Lessa e Maria Conceição;

Aos meus avós, Francisco (in memoriam) e Giva;

Pelo amor incondicional, incentivo e apoio em todos os momentos.

Dedico 


\section{AGRADECIMENTOS}

À Deus, pela vida, proteção e por ter permitido mais esta vitória.

À Escola Superior de Agricultura "Luiz de Queiroz" - ESALQ, em especial ao Programa de Pós-graduação em Genética e Melhoramento de Plantas, pela oportunidade de realizar este curso.

À Fundação de Amparo à Pesquisa do Estado de São Paulo - FAPESP, pela concessão da bolsa de estudo e auxílio financeiro à pesquisa.

Ao prof. Luis Eduardo Aranha Camargo, pela orientação, confiança, incentivo e apoio durante a realização deste trabalho.

Ao prof. Magno Antonio Patto Ramalho, da Universidade Federal de Lavras, por ser um dos principais responsáveis pela minha opção pela área de Genética e Melhoramento de Plantas com seu exemplo de dedicação à pesquisa.

Ao prof. Roland Vencovsky, pelo apoio, sugestões e correções que contribuíram para a melhoria da qualidade deste trabalho.

Ao prof. Hiroshi Kimati e funcionários do departamento de Fitopatologia, pelo apoio e amizade.

Aos professores e funcionários do departamento de Genética da ESALQ, pelo apoio e ensinamentos transmitidos.

Ao Dr. Herberte Pereira da Silva pelas sugestões e apoio na elababoração do trabalho.

À empresa Sementes DowAgroSciences, pelo fornecimento do material vegetal, funcionários e instalações para a condução dos experimentos de campo. 
Ao Fernando, pelo amor, apoio irrestrito e incentivo em todos os momentos.

Aos amigos do Laboratório de Genética Molecular, Maria Cristina, Alessandra Penha, Paulo, Marcelo, Cláudia, Maeli, Daniela, Giovana, Rodrigo, Vanoli, Patrícia, Cristina, Jaqueline, Maria Teresa, Ademir, Flávia, Camila, Ana Paula, Alessandra, Tatiana, Evandro, Carol, Kátia, Célia, Osmar, Raphaelle, Fernando, André, Raul, Mariana, Adriane e Alice, pelo agradável convívio e apoio durante a realização deste trabalho.

Aos amigos da pós-graduação em Genética e Melhoramento de Plantas, pelos bons momentos compartilhados.

Aos amigos, Eulália, Cibele, Nancy e Aurélio, pelas alegrias compartilhadas e ajuda nos momentos difíceis. 


\section{SUMÁRIO}

Página

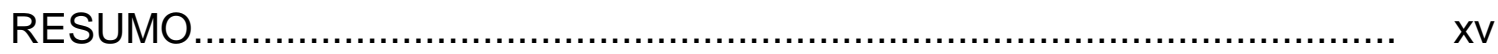

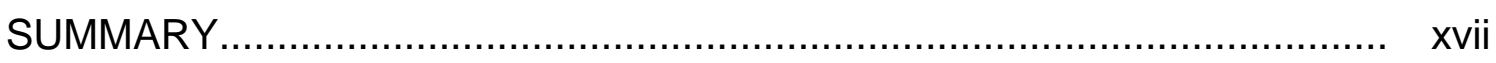

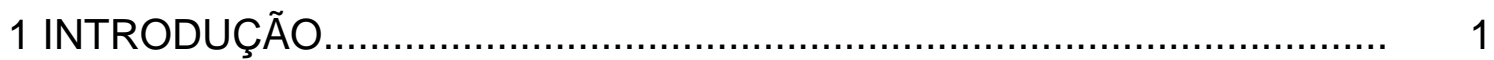

2 REVISÃO DE LITERATURA......................................................... 3

2.1 Etiologia e epidemiologia................................................................ 3

2.2 Resistência genética a Colletotrichum graminicola................................ 5

2.3 Estudos de herança genética .......................................................... 6

2.4 Marcadores moleculares................................................................... 9

2.5 Construção de mapas genéticos...................................................... 11

2.6 Análise de bulks segregantes........................................................ 13

2.7 Detecção e mapeamento de QTLs................................................... 14

2.8 Mapeamento de genes de resistência a doenças em milho.................... 19

3 MATERIAL E MÉTODOS................................................................ 23

3.1 Modelo de herança mista para resistência a C. graminicola................... 23

3.1.1 Genótipos utilizados..................................................................... 23

3.1.2 Obtenção do inóculo............................................................... 24

3.1.3 Avaliação da reação a C. graminicola em quatro cruzamentos............ 24

3.1.4 Análises estatísticas................................................................... 26

3.1.4.1 Análises de variância.......................................................... 26

3.1.4.2 Modelos genéticos e testes de hipóteses...................................... 27

3.2 Mapeamento de genes de resistência a C. graminicola.......................... 30

3.2.1 População de mapeamento ...................................................... 30

3.2.2 Avaliação da reação a C. graminicola em famílias $\mathrm{F}_{12} \mathrm{RC}_{1 \ldots \ldots \ldots \ldots \ldots \ldots . .} \quad 30$ 
3.2.3 Genotipagem com marcadores moleculares................................... 33

3.2.3.1 Extração e quantificação de DNA................................................. 33

3.2.3.2 Genotipagem com marcadores microssatélites.............................. 34

3.2.3.3 Genotipagem com marcadores AFLP ........................................ 35

3.2.3.4 Testes de segregação mendeliana.............................................. 40

3.2.3.5 Análise de marcas simples e construção do mapa de ligação.......... 41

3.2.3.6 Análise de regressão linear múltipla ............................................. 42

3.2.3.7 Mapeamento de QRLs por intervalo composto............................... 43

4 RESULTADOS E DISCUSSÃO.......................................................... 44

4.1 Modelo de herança mista para resistência a C. graminicola................... 44

4.1.1 Avaliação da reação a C. graminicola em quatro cruzamentos........... 44

4.1.2 Testes de hipóteses sobre os modelos de herança genética.............. 51

4.1.3 Parâmetros genéticos para resistência a C. graminicola..................... 55

4.2 Mapeamento de genes de resistência a C. graminicola......................... 59

4.2.1 Avaliação da reação a $C$. graminicola em famílias $\mathrm{F}_{1: 2} \mathrm{RC}_{1} \ldots \ldots \ldots \ldots \ldots \ldots . . . . . .59$

4.2.2 Análise de marcadores microssatélites............................................ 62

4.2.3 Análise de marcadores AFLP................................................... 66

4.2.4 Análise de marcas simples e construção do mapa de ligação.............. 71

4.2.5 Regressão linear linear múltipla..................................................... 73

4.2.6 Mapeamento por intervalo composto............................................. 76

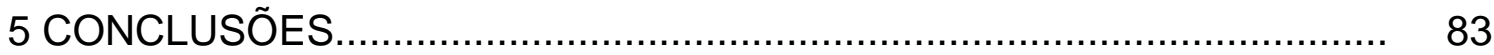

REFERÊNCIAS BIBLIOGRÁFICAS...................................................... 84 


\title{
ANÁLISE GENÉTICA DA RESISTÊNCIA À ANTRACNOSE FOLIAR EM MILHO
}

\author{
Autora: VIVIANE FERREIRA REZENDE \\ Orientador: Prof. Dr. LUIS EDUARDO ARANHA CAMARGO
}

\section{RESUMO}

Os objetivos do presente trabalho foram estudar a herança da resistência à antracnose foliar em milho, estimar os parâmetros genéticos e identificar marcadores moleculares ligados a genes de resistência a esta doença. Parâmetros genéticos foram estimados com base na análise de modelos de herança mista de seis gerações de quatro cruzamentos entre duas linhagens resistentes (DAS4 e DAS3) e duas linhagens suscetíveis (DAS6 e DAS22). O delineamento experimental foi 0 de blocos casualizados com parcelas subdivididas, com três repetições, sendo as parcelas constituídas pelos cruzamentos e as subparcelas, pelas gerações. As plantas foram inoculadas artificialmente e avaliadas em dois experimentos através de uma escala de notas de 1 a 6 . Os testes de hipóteses para selecionar o modelo de herança genética e as estimativas dos parâmetros foram realizados pelo método da máxima verossimilhança. Os resultados da análise de modelos mistos indicaram que a resistência é controlada por um gene de efeito maior em todos os cruzamentos e experimentos avaliados e também por poligenes, em pelo menos um dos experimentos. A ação gênica é aditiva e dominante, com 
predominância de efeitos genéticos aditivos. O mapeamento de QRLs foi realizado utilizando 141 indivíduos $F_{1} R C_{1}$ do cruzamento (DAS6 $x$ DAS4) $x$ DAS6, com base na avaliação fenotípica das suas famílias, em dois experimentos. O delineamento experimental foi o látice $12 \times 12$, incluindo as famílias, genitores e híbrido, com 3 repetições. As plantas foram inoculadas artificialmente e avaliadas através de uma escala de notas de 1 a 6 . 0 mapeamento de QRLs, utilizando marcadores microssatélites e AFLPs e análise de bulks segregantes para detecção de marcadores candidatos, foi realizado pela análise de regressão linear múltipla ( $R L M)$ e pelo mapeamento por intervalo composto (MIC). Ambas metodologias de análise identificaram pelo menos um QRL no cromossomo 10 em cada experimento. Também foram detectados QRLs nos cromossomos 2, 3 e 5, apenas pela RLM. Os QRLs identificados pela RLM explicaram $25,7 \%, 23,3 \%$ e $24,5 \%$ da variação fenotípica no experimento 1, no experimento 2 e na análise conjunta, respectivamente. Já os QRLs identificados pelo MIC explicaram 28,9\%, 32,3\% e $31,0 \%$ da variação fenotípica no experimento 1 , no experimento 2 e na análise conjunta, respectivamente. A análise de bulks segregantes permitiu a detecção apenas dos QRLs de efeitos fenotípicos mais expressivos localizados no cromossomo 10. Na maioria dos QRLs detectados, os alelos de resistência provieram do genitor resistente. A identificação destes QRLs oferece uma significativa contribuição para o entendimento da resistência de milho à antracnose foliar, podendo levar à identificação de genes e elucidação dos mecanismos envolvidos na expressão da resistência. 


\title{
GENETIC ANALYSIS OF RESISTANCE TO ANTHRACNOSE LEAF BLIGHT IN MAIZE
}

\author{
Author:VIVIANE FERREIRA REZENDE \\ Adviser: Prof. Dr. LUIS EDUARDO ARANHA CAMARGO
}

\section{SUMMARY}

The objectives of this work were to study the inheritance of resistance to anthracnose leaf blight, estimate the genetic parameters, and identify molecular markers associated with resistance genes to this disease. Genetic parameters were estimated based on the analysis of mixed inheritance models in six generations of four crosses between two resistant (DAS4 and DAS3) and two susceptible inbred lines (DAS6 and DAS22). The experimental design consisted of randomized blocks containing split-plots, with three replicates, where the plots were represented by crosses and the subplots were the generations. The plants were inoculated artificially and evaluated in two experiments by means of a rating scale from 1 to 6 . The hypothesis testing to select the genetic inheritance model and parameter estimates were obtained by the maximum likelihood method. The results from the mixed models analysis indicated that resistance is controlled by a major gene in all crosses and experiments evaluated, and also by polygenes in at least one experiment. The genetic action is additive and dominant, with predominance of additive genetic effects. QRL mapping was performed using $141 \mathrm{~F}_{1} \mathrm{RC}_{1}$ individuals from the (DAS6 $\times$ DAS4) $\times$ DAS6 cross, based on the phenotypic evaluation of their families, in two experiments. The 
experimental design was a $12 \times 12$ lattice which included the families, parents, and the hybrid, with 3 replicates. The plants were inoculated artificially and evaluated by means of a rating scale from 1 to 6 . QRL mapping, using microsatellites and AFLPs markers, and bulked segregant analysis to detect candidate markers was performed by multiple linear regression analysis (MLR) and by composite interval mapping (CIM). Both methodologies of analysis identified at least one QRL in chromosome 10 in each experiment. QRLs were also detected, by MLR only, in chromosomes 2, 3 and 5. The QRLs identified by MLR explained $25.7 \%, 23.3 \%$, and $24.5 \%$ of the phenotypic variation in the experiment 1 , in the experiment 2 and in the joint analysis, respectively. The QRLs identified by CIM, however, explained $28.9 \%, 32.3 \%$, and $31.0 \%$ of the phenotypic variation in the experiment 1 , in the experiment 2 and in the joint analysis, respectively. The bulked segregant analysis only allowed the detection of QRLs that showed the more expressive phenotypic effects located in chromosome 10. In most detected QRLs, the resistance alleles came from the resistant parent. The identification of these QRLs offers a significant contribution to an understanding of resistance to anthracnose leaf blight in maize, and could lead to the identification of genes and to an elucidation of the mechanisms involved in the expression of resistance. 


\section{INTRODUÇÃO}

A antracnose, causada pelo fungo Colletotrichum graminicola (Ces.) Wils., é uma doença de importância mundial (Bergstrom \& Nicholson, 1999). O fungo afeta todas as partes da planta, mas a queima foliar e a podridão de colmo são os tipos de infecção mais comuns (Dale, 1963). Em alguns países como França, Índia e Filipinas, a antracnose é um fator limitante à cultura do milho (Shurtleff, 1980). Nos Estados Unidos, epidemias severas chegaram a inviabilizar a cultura do milho doce no Estado de Indiana, dois anos após sua primeira aparição (Warren et al., 1973; Bergstrom \& Nicholson, 1999). No Brasil, a antracnose vem se tornando limitante à produtividade das lavouras de milho nas últimas safras devido, principalmente, ao cultivo safrinha e ao plantio direto, práticas que aumentam a disponibilidade de tecido hospedeiro (Morello, 2000).

Relatos de perdas na produtividade de grãos ocasionadas pela podridão do colmo e queima foliar variam de zero a mais de $40 \%$, dependendo do genótipo da planta, ambiente e época de infecção (Callaway et al., 1992; Keller et al., 1986; Perkins \& Hooker, 1979; Smith, 1976). No Brasil, a antracnose foi relatada pela primeira vez em campos de produção de sementes de milho híbrido na região de Campinas (SP), por volta de 1965 (Silveira et al., 1965). Neste relato, os autores referiram-se a perdas de até 30\%. O patógeno já foi identificado nas regiões Centro-Oeste, Sul, Sudeste (Fernandes \& Balmer, 1990) e nos estados de Pernambuco e Paraíba (Pontes, 1987).

Diante da potencialidade da doença, sobretudo em sua forma foliar devido à maior facilidade de disseminação dos esporos, o emprego de genótipos resistentes surge como promissor e talvez único método de controle. 
Estudos mostram que a resistência a $C$. graminicola é controlada por um a quatro genes, com presença de ação gênica aditiva e dominante, sendo a ação aditiva de maior importância (Carson \& Hooker, 1981a; Carson \& Hooker, 1981b; Badu-Apraku et al., 1987; Lim \& White, 1978; Coêlho et al., 2001; Siva et al., 1986). Uma característica comum aos trabalhos citados é que a estimativa de parâmetros associados a poligenes e a genes de efeito maior é feita de maneira independente, ou seja, usando metodologias distintas. No entanto, quando a característica em questão tem distribuição contínua, é interessante verificar se ocorre um gene de efeito maior ou se a herança é essencialmente poligênica. Modelos que estimam tanto a ação de genes de efeito maior como de poligenes são denominados modelos de misturas ou modelos de herança mista (Gai \& Wang, 1998) e ainda não foram aplicados ao estudo das bases genéticas de resistência a doenças em plantas.

Além dos estudos de herança clássicos, a caracterização dos genes de resistência por meio de marcadores moleculares pode contribuir grandemente para o entendimento da genética da resistência e ainda auxiliar programas de melhoramento na seleção e introgressão desses genes. Entretanto, trabalhos objetivando detectar genes de resistência à antracnose foliar em milho são ausentes na literatura.

Diante do exposto, o presente trabalho objetivou estudar a herança da resistência à antracnose foliar em milho, estimar os parâmetros genéticos e identificar marcadores moleculares ligados a genes de resistência utilizando linhagens derivadas de germoplasma tropical. 


\section{REVISÃO DE LITERATURA}

\subsection{Etiologia e epidemiologia}

A antracnose é causada pelo fungo Colletotrichum graminicola Ces Wils., cuja fase sexual corresponde a Glomerella graminicola Politis. Esta fase raramente é observada na natureza e caracteriza-se pela presença de peritécios, no interior dos quais são produzidas ascas cilíndricas a clavadas, que contêm ascósporos hialinos e unicelulares. Em sua forma assexuada (imperfeita), o fungo produz frutificações denominadas acérvulos, de coloração escura e formato oval a cilíndrico. Estas estruturas apresentam numerosas setas de coloração escura e se formam na epiderme e cavidades subepidérmicas de ambas as superfícies da folha ou do colmo. Os conidióforos, produzidos em grande quantidade no interior dos acérvulos, são eretos, hialinos e não apresentam septos. Os conídios de $C$. graminicola, produzidos terminalmente sobre os conidióforos, são hialinos, não septados e falciformes (Casela \& Ferreira, 1998).

O fungo pode sobreviver em colmos infectados por um período de até dez meses (Naylor \& Leonard, 1977) e em sementes armazenadas durante três anos (Warren,1977). O aumento da doença é menos dramático em áreas de produção de silagem, nas quais a maior parte dos tecidos do milho é removida do campo após a colheita (Bergstrom \& Nicholson, 1999).

C. graminicola pode colonizar qualquer parte da planta. Nas folhas, as lesões necróticas de coloração pardacenta, a princípio arredondadas ou ovaladas, podem fundir-se e ocasionar danos extensos. No colmo, os sintoma 
geralmente surgem na epiderme, logo após a polinização, como lesões estreitas, longitudinais e "encharcadas", inicialmente de coloração pardoavermelhadas, que se tornam castanho-escuras. Além das folhas e colmo, este patógeno também pode afetar raiz, palha (bráctea) e semente (Warren et al., 1973; Dale, 1963).

A infecção de folhas de plântulas ocorre a partir de esporos produzidos em acérvulos sobre restos de cultura, sendo a dispersão de esporos limitada a curtas distâncias. Portanto, práticas culturais são importantes para o controle da doença. Entretanto, podem ser insuficientes no caso de plantio tardio, onde o patógeno é endêmico. A antracnose foliar pode ser tão severa em genótipos suscetíveis a ponto de restringir seu crescimento normal e desenvolvimento, podendo resultar na morte da plântula (Bergstrom \& Nicholson, 1999). A doença é mais evidente em plântulas com até um mês e em plantas adultas após a antese (Badu-Apraku et al., 1987).

O inóculo secundário vem de lesões nas folhas inferiores. Os conídios são disseminados pelo vento ou por respingos de chuva. Conídios que servem como inóculo secundário para a infecção foliar também servem como inóculo para infecção do colmo (Bergstrom \& Nicholson, 1999).

A presença de água mostra-se necessária para a germinação dos conídios, sendo a doença favorecida por alta umidade e temperaturas moderadas (Jamil \& Nilcholson, 1987). Apesar da germinação e formação do apressório ocorrerem numa ampla faixa de temperatura $\left(15\right.$ a $35^{\circ} \mathrm{C}$ ), a penetração do hospedeiro ocorre apenas entre 25 e 30 ${ }^{\circ} \mathrm{C}$ (Skoropad, 1967).

Além do milho, isolados de $C$. graminicola podem infectar aveia, cevada e trigo. A capacidade de isolados obtidos de milho infectarem sorgo ainda é discutida (Shurteleff, 1980). Conídios de C. graminicola de gramíneas próximas à cultura podem infectar folhas maduras, mas apenas inóculo de isolados de milho pode ocasionar epidemias (Bergstrom \& Nicholson, 1999). 
No patossistema C. graminicola x Zea mays, a variabilidade do patógeno já foi demonstrada (White et al., 1987; Nicholson \& Warren, 1976; Forgey et al., 1978) mas, com relação à distinção de raças fisiológicas, ainda não há um consenso. Forgey et al. (1987) relataram a ocorrência de oito raças fisiológicas de C. graminicola. Entretanto, Nicholson \& Warren (1981), trabalhando com sete dos dez isolados utilizados por Forgey et al. (1987), não obtiveram sucesso em reproduzir os resultados destes autores.

\subsection{Resistência genética a Colletotrichum graminicola}

Há ampla variabilidade genética para resistência a $C$. graminicola entre linhagens e híbridos (Badu-Apraku et al.,1987; Carson \& Hooker, 1981a; Carson \& Hooker, 1981b; Zuber et al.,1981; Keller \& Bergstrom, 1988). Estes estudos indicam que a resistência a antracnose foliar é controlada por poucos (um a quatro) genes dominantes. Efeitos genéticos aditivos e de dominância foram relatados, sendo os efeitos aditivos de maior importância (Carson \& Hooker, 1981a; Carson \& Hooker, 1981b; Badu-Apaku et al., 1987, Lim \& White, 1978, Siva et al, 1986). Desvios significativos do modelo dominante-aditivo também foram relatados (Carson \& Hooker, 1981a; Carson \& Hooker, 1981b), os quais podem resultar da falta de uma escala adequada para medir os sintomas da doença, epistasia ou falha no atendimento das pressuposições da análise de médias de gerações (Mather \& Jinks, 1971). Há indícios prévios de segregação monogênica da resistência na população $F_{2}$ proveniente do cruzamento entre as linhagens DAS6 e DAS4, as quais foram utilizadas no presente trabalho (Coêlho et al., 2001). É importante ressaltar que a avaliação realizada por estes autores foi qualitativa, ou seja, foi observado apenas a presença ou a ausência de sintomas nas plantas, o que impede a detecção de genes de pequeno efeito na resistência. 
Pouco se sabe sobre os mecanismos de expressão dos genes de resistência. Entretanto, respostas bioquímicas e fisiológicas à infecção fúngica em milho são conhecidas. Geralmente, a reação de resistência em folhas envolve estímulo à biossíntese de compostos fenólicos, especialmente fenilpropanóides (Bergstrom \& Nicholson, 1999). A lignina, por exemplo, tem sua síntese ativada em dois momentos: antes do fungo penetrar na célula hospedeira, formando uma papila lignificada na parede externa da célula epidérmica (Cadena-Gomez et al., 1987), e após a penetração do fungo, formando uma barreira física e química em torno da lesão e, consequentemente, restringindo o crescimento do fungo (Lyons et al., 1993).

O acúmulo de antocianina ao redor das lesões ocorre em alguns cultivares de milho mantidos sob alta intensidade luminosa (Hammerschmidt \& Nicholson, 1977), a qual aumenta a resistência da planta. Contrariamente, a redução da intensidade de luz resulta em aumento no nível de suscetibilidade (Schall et al., 1980).

\subsection{Estudos de herança genética}

Estudos de herança genética são relativamente simples quando a característica em questão é qualitativa e, portanto, apresenta distribuição discreta. Nestes casos, são feitos testes de aderência para verificar se a segregação observada ajusta-se à esperada considerando-se diferentes hipóteses. Entretanto, se a característica de interesse tiver distribuição contínua, é freqüente a utilização de modelos de genética quantitativa, os quais assumem um grande número de locos de efeitos aproximadamente iguais e pequenos. Dispondo-se de genitores contrastantes $\left(P_{1}\right.$ e $\left.P_{2}\right)$ e das gerações $F_{1}$, $F_{2}, R_{1}$ e $R C_{2}$, podem-se estimar componentes de variâncias e de médias. Uma das metodologias mais utilizadas para inferir sobre componentes de médias é o teste de escala conjunto, descrito por Mather \& Jinks (1971). 
Entretanto, uma vez que a distribuição fenotípica contínua nem sempre é sinônimo de herança poligênica, a validade desta metodologia é grandemente comprometida se genes de efeito maior também contribuírem para a expressão do caráter. Caso a variação ambiental seja suficientemente grande em relação ao efeito individual de qualquer gene, efeitos de genes maiores podem ser completamente obscurecidos e confundidos com efeitos de poligenes (Lynch \& Walsh, 1998). Portanto, quando a característica em questão tem distribuição contínua, é interessante verificar se ocorre um gene de efeito maior ou se a herança é essencialmente poligênica. A distinção entre efeitos de genes maiores e efeitos de poligenes é importante para o entendimento da expressão do gene maior em relação à constituição genética (poligênica e, ou ambiental) e para a predição da segregação de um cruzamento (Jiang, 1994). Os testes mais poderosos para a detecção de genes maiores são aqueles que usam a informação de marcadores moleculares ligados. Entretanto, dados puramente fenotípicos também podem ser usados para inferir sobre a presença ou ausência desses genes (Lynch \& Walsh, 1998).

Considerando a segregação de um gene maior e assumindo que a distribuição fenotípica de cada genótipo do gene maior (AA, Aa e aa) seja normal, a distribuição resultante, ou seja, uma mistura de distribuições normais, é geralmente não normal. Entretanto, a simples rejeição de normalidade, por si só, não é suficiente para inferir sobre a presença de um gene de efeito maior. Assim, uma abordagem mais poderosa é testar se a distribuição fenotípica resulta da mistura de duas ou mais distribuições normais (Lynch \& Walsh, 1998).

Modelos de misturas de distribuições normais, ou modelos de herança mista, são usados no estudo de caracteres quantitativos visando à estimativa de parâmetros genéticos que descrevem a variação do caráter (Wang \& Gai, 2001). Nesta abordagem, cada genótipo do gene de efeito maior corresponde a um valor genotípico esperado, em torno do qual ocorre uma variação. Esta 
variação é devida a efeitos ambientais somados ou não à ação de poligenes. A metodologia considera diferentes modelos de maneira hierárquica, partindo de um modelo mais simples, que inclui apenas efeitos ambientais, até um modelo que inclui tanto um gene de efeito maior quanto poligenes (Silva, 2003).

Há alguns relatos de análises que utilizam modelos de misturas em populações humanas e animais (Elston \& Stewart, 1973; Morton \& MacLean, 1974; Knott et al., 1991; Le Roy et al., 1990; Janss et al., 1995; Shoukri \& McLachlan, 1994). Métodos similares que utilizam a máxima verossimilhança também foram desenvolvidos para analisar locos maiores em gerações segregantes derivadas de cruzamento entre linhagens endogâmicas de plantas (Tourjee et al., 1995; Loisel et al., 1994; Jiang et al., 1994). Geralmente, as estimativas de máxima verossimilhança dos parâmetros são obtidas utilizandose o algoritmo EM (Dempster et al., 1977), que alterna passos de esperança e maximização. Um outro contexto da genética no qual modelos de misturas são utilizados em associação com o algoritmo EM é o mapeamento de QTLs. A natureza da mistura, neste caso, se deve ao fato de que em cada genótipo do loco marcador ocorrem diferentes genótipos quanto a QTLs, devido à recombinação entre loco marcador e QTL (Silva, 2003).

Quando a variação (ambiental e eventualmente poligênica) é de mesma natureza dentro de cada componente da mistura, a implementação do algoritmo EM é relativamente simples. Por outro lado, quando a amostra apresenta categorias dentro das quais a variação é de natureza particular, como é o caso de quando se utilizam diferentes gerações (ex.: $P_{1}, P_{2}, F_{1}, F_{2}, R C_{1}$ e $R C_{2}$ ), a obtenção das expressões correspondentes aos passos $E$ e $M$ não é direta, sendo necessárias consideráveis adaptações (Silva, 2003). Nestes casos, os algoritmos numéricos Newton-Raphson, Quase-Newton e Powell seriam mais apropriados (Kennedy \& Gentle, citados por Silva, 2003). O software Monogen versão 0.1 (Silva, 2003), utilizado para a obtenção das estimativas dos parâmetros genéticos e testes de hipóteses pelo critério da máxima 
verossimilhança, integra uma combinação dos métodos Quase-Newton e Powell.

\subsection{Marcadores moleculares}

O desenvolvimento de marcadores moleculares possibilitou utilizar a variabilidade genética existente no DNA para a identificar genes de importância agronômica. Os tipos de marcadores moleculares hoje disponíveis, diferenciamse quanto à forma utilizada para identificar a variabilidade no DNA. Os principais tipos de marcadores moleculares podem ser classificados em dois grupos: aqueles baseados na hibridização do DNA genômico com sondas ou aqueles baseados na amplificação de fragmentos de DNA via PCR (Polymerase Chain Reaction). Entre os identificados por hibridização estão os marcadores RFLP (Restriction Fragment Length Polymorphism) e Minissatélites, ou locos VNTR (Variable Number of Tandem Repeats). Já aqueles revelados por amplificação incluem os marcadores RAPD (Random Amplified Polymorphic DNA), SCAR (Sequence Characterized Amplified Regions), Microssatélites ou SSR (Simple Sequence Repeats) e AFLP (Amplified Fragment Length Polymorphism).

Dentre os marcadores mais informativos baseados nas diferenças de comprimento das seqüências amplificadas pela reação da polimerase ou PCR estão os microssatélites. Estes marcadores amplificam regiões contendo seqüências repetitivas de DNA de comprimento variável (Mullis et al., 1986). Microssatélites são extensões em tandem de pequenas seqüências que variam de um a seis nucleotídeos comumente repetidas de 10 a 60 vezes (Gupta et al., 1996), centenas de vezes (Mörchen et al., 1996) ou milhares de vezes (Brown et al., 1996). Microssatélites normalmente são flanqueados por segmentos de DNA únicos e conservados. Dessa forma, torna-se possível a escolha de primers que amplificam especificamente um único loco de microssatélite. $O$ 
comprimento do fragmento amplificado normalmente se encontra entre 50 e 300 pares de base (pb) (Tautz, 1989).

A natureza altamente mutável de locos microssatélites aumenta o número de variantes alélicos em cada loco. A variabilidade de microssatélites provavelmente se origina de crossing-over desigual ou deslizamento da enzima DNA polimerase durante a replicação do DNA. Se o pareamento for feito com uma seqüência repetida erroneamente posicionada na outra fita, a DNA polimerase pode adicionar ou deletar uma ou mais cópias da repetição da nova fita de DNA em um processo conhecido como slippage (Tautz et al., 1986). A variação no comprimento do produto amplificado é função do número de unidades de seqüências repetidas. Assim, segmentos de tamanhos diferentes representam alelos.

Microssatélites possuem a vantagem de apresentarem herança Mendeliana e de serem altamente reproduzíveis, locus específicos, codominantes e hipervariáveis. Eles permitem, virtualmente, a utilização de qualquer população segregante para estudos de ligação (Chin et al., 1996). Consequentemente, têm sido propostos como marcadores de escolha geral para o mapeamento genético de eucariotos. Estes marcadores já foram descritos em inúmeras espécies vegetais como arroz (Wu \& Tanksley, 1993), milho (Smith et al., 1997), soja (Rongwen et al., 1995), Brassica (Lagercrantz et al., 1993), arabidopsis (Bell \& Ecker, 1994), videira (Browers et al., 1996), árvores tropicais (Condit \& Hubbell, 1991), trigo e cevada (Saghai-Maroof et al., 1994) entre outras.

Outro eficiente método baseado na PCR, denominado AFLP (Vos et al., 1995), combina a especificidade, resolução e poder de amostragem da digestão com enzimas de restrição com a velocidade e praticidade de detecção dos polimorfismos via PCR. A análise de AFLP consiste essencialmente de quatro etapas. Na primeira etapa o DNA genômico total é clivado com duas enzimas de restrição, uma de corte raro (reconhece sítios de 6-8 bases, ex.: EcoRI, 
Hindll e Pstl) e outra de corte freqüente (reconhece sítios de 4 bases, ex.: Msel e Taql). Na segunda etapa, adaptadores específicos são ligados às extremidades coesivas dos fragmentos genômicos gerados pela clivagem. $\mathrm{Na}$ terceira etapa, uma fração dos fragmentos gerados é amplificada seletivamente via PCR utilizando primers específicos complementares às seqüências dos adaptadores. São feitas duas amplificações. Na primeira, denominada préseletiva, um subconjunto de fragmentos é amplificado com primers que apresentam um nucleotídeo arbitrário na extremidade 3'. Na segunda amplificação é feita uma seleção mais intensa dos fragmentos pré-amplificados, utilizando dois nucleotídeos arbitrários adicionais, além do primeiro utilizado na amplificação pré-seletiva. Na quarta e última etapa, os fragmentos amplificados são separados em gel de alta resolução (Ferreira \& Grattapaglia, 1998).

As principais vantagens dos marcadores AFLP são: alto índice de "multiplex", ou seja, grande número de marcadores analisados em um único gel, e o fato de não ser necessário o conhecimento prévio da seqüência de bases, como no caso dos microssatélites (Vuylsteke et al., 1999). A técnica de AFLP tem sido utilizada com sucesso para identificar marcadores ligados a locos de resistência a doenças (Meksem et al., 1995; Thomas et al., 1995; Cervera et al., 1996; Vos et al., 1998), análises de germoplasma (Zhu et al., 1998) e na construção de mapas genéticos de cevada (Qi et al., 1998), eucalipto (Marques et al., 1998), batata (van Eck et al., 1995), arroz (Zhu et al., 1998), soja (Keim et al., 1997) e milho (Vuylsteke et al., 1999; Castiglione et al., 1999).

\subsection{Construção de mapas genéticos}

Mapas genéticos representam a ordem de locos ao longo de um cromossomo bem como as distâncias relativas entre eles. Tais mapas são essenciais para a localização de QTLs (quantitative trait locl) (Lynch \& Walsh, 
1998). Marcadores utilizados no mapeamento devem ser polimórficos entre os genitores e apresentar segregação Mendeliana. Quanto maior for a distância genética entre os genitores que darão origem à população a ser utilizada no mapeamento, maior a chance de detectar polimorfismos, ou seja, presença de mais de uma forma alélica. Também é importante que o mapeamento seja feito utilizando fontes de germoplasma de interesse para o melhoramento da espécie (Milach, 1998).

As populações $F_{2}, F_{3}$ e retrocruzamentos são as mais utilizadas para a construção de mapas genéticos. Em espécies que toleram alto grau de endogamia, podem ser utilizadas linhagens endogâmicas recombinantes que, apesar do menor desequilíbrio de ligação, permitem a repetição dos experimentos em épocais e locais diferentes, aumentando a precisão e enriquecendo as avaliações fenotípicas (Tanksley, 1993). Outros tipos de populações utilizadas são linhagens duplo-haplóides obtidas de gametas de plantas $F_{1}$ e cruzamentos entre indivíduos heterozigotos.

A máxima resolução de um mapa é estabelecida pelo número de indivíduos genotipados na população e pelo número de marcadores genéticos utilizados (Liu, 1998). A distância entre marcadores é obtida através da freqüência de recombinação, que estima a probabilidade de ocorrência de permuta genética entre dois marcadores. As freqüências de recombinação não são aditivas devido ao fenômeno da interferência, ou seja, a ocorrência de uma permuta genética afeta a ocorrência de permutas em regiões adjacentes. As distâncias de mapa, em centiMorgans (cM), são calculadas com base nas freqüências de recombinação através de funções de mapeamento. Várias funções de mapeamento relacionando as medidas de distância às freqüências de recombinação foram desenvolvidas, sendo as funções de Haldane (1919) e Kosambi (1944) as mais utilizadas. A função proposta por Haldane (1919) assume a ocorrência de permutas independentes ao longo do cromossomo. Já a função Kosambi (1944) acrescenta a pressuposição de que ocorre uma 
interferência completa entre regiões arbitrariamente próximas, sendo esta interferência decrescente para locos mais distantes e igual a zero para locos independentes.

Embora a freqüência de recombinação esteja associada à distância física entre os locos, esta relação varia entre organismos e ao longo do genoma de um mesmo organismo (Liu, 1998). Em Arabidopsis, por exemplo, $1 \mathrm{cM}$ equivale a $140 \mathrm{~kb}$ ( $1 \mathrm{~kb}=1.000$ pares de bases); em milho, equivale a $2.000 \mathrm{~kb}$ (Lynch \& Walsh, 1998).

\subsection{Análise de bulks segregantes}

O primeiro passo do mapeamento de QTLs é a identificação de marcadores que revelem polimorfismo entre os genitores e que, portanto, segregarão na população proveniente do cruzamento entre eles. Para isso, o DNA dos genitores é analisado com diferentes marcadores. Esta análise, embora revele polimorfismos, não fornece informações sobre qual dos polimorfismos encontrados está ligado à genes de interesse. Esta associação pode ser feita através da análise de bulks segregantes ou BSA (Arnheim et al., 1985; Michelmore et al., 1991). Esta análise se baseia na constituição de bulks (ou misturas) de amostras de DNA de indivíduos com fenótipos extremos pertencentes à população segregante. Presume-se que locos marcadores ligados a genes que controlam o fenótipo de interesse estejam distribuídos de forma desigual nos dois bulks (desequilíbrio de ligação), sendo detectados por meio de polimorfismos entre eles. Entretanto, marcadores não ligados devem estar distribuídos aleatoriamente nos bulks sendo, portanto, monomórficos entre eles. Marcadores polimórficos entre bulks são posteriormente analisados na população para confirmação da ligação e determinação da distância genética dos mesmos em relação aos genes estudados. 
A análise de bulks segregantes é limitada para a detecção de QTLs de pequeno efeito (Lynch \& Walsh, 1998), porém, permite uma rápida análise de um grande número de marcadores e conseqüente otimização do mapeamento de regiões que flanqueiam locos de caracteres quantitativos de efeitos fenotípicos mais pronunciados. Na técnica BSA, apenas polimorfismos para marcadores localizados a menos de $30 \mathrm{cM}$ da região alvo são identificados, segundo estudo envolvendo populações $F_{2}$ (Michelmore et al., 1991).

A probabilidade de detecção de falsos positivos na BSA, ou seja, marcadores polimórficos entre bulks mas não ligados a QTLs, é bastante reduzida. O tamanho mínimo do bulk é determinado pela freqüência com que locos não ligados devem ser detectados como polimórficos entre as amostras. Isto depende de tipo de marcador (dominante ou codominante) e do tipo de população usada para gerar os bulks ( $F_{2}$, retrocruzamentos, etc). Para um marcador dominante segregando em uma população $F_{2}$, a probabilidade de um bulk de $\mathrm{n}$ indivíduos ter um alelo marcador e um segundo bulk de igual tamanho não ter este alelo é de $2\left[1-(1 / 4)^{n}\right](1 / 4)^{n}$, quando o loco é não ligado ao gene alvo. Portanto, poucos indivíduos por bulk são requeridos (Michelmore et al., 1991). Entretanto, quanto menor o bulk maior a freqüência de falsos positivos.

\subsection{Detecção e mapeamento de QTLs}

Os princípios do mapeamento genético de características qualitativas e quantitativas são os mesmos. Entretanto, o mapeamento destas características difere em alguns aspectos, como a necessidade de construção de um mapa genético da espécie, no caso de características quantitativas. Outro aspecto que diferencia o mapeamento de características qualitativas e quantitativas são os programas estatísticos utilizados para a análise de ligação gênica (Milach, 1998). A existência de desequilíbrio de ligação, decorrente da redução da freqüência de recombinação entre genes ligados, fundamenta as análises de 
mapeamento de genes. Assim, são os desvios em relação às proporções esperadas pela segregação independente de alelos de locos diferentes que permitem a detecção e o mapeamento de QTLs (Coelho, 2000).

As considerações relativas à escolha de genitores e tipo de população para a construção de mapas genéticos também se aplicam ao mapeamento de QTLs. Quanto maior o genoma de uma espécie, mais difícil será encontrar um marcador associado a um QTL de interesse. Neste caso, para aumentar a probabilidade de detecção de QTLs, é importante utilizar marcadores que permitam uma boa amostragem do genoma. A técnica de AFLP permite a obtenção de grande número de locos por reação, o que a torna adequada para esta finalidade. Como os marcadores AFLP são dominantes, a utilização de populações de retrocruzamentos com o genitor suscetível, nos casos em que a resistência é dominante e os alelos de resistência se encontram no genitor resistente, é uma boa opção. Isto ocorre pelo fato deste tipo de população apresentar apenas duas classes genotípicas (heterozigótica e homozigótica recessiva) sendo, neste caso, os marcadores dominantes tão informativos quanto os codominantes.

Há vários procedimentos estatísticos para determinar se um gene está ligado a um loco marcador. Todos os procedimentos compartilham o mesmo princípio básico que consiste em dividir a população em diferentes classes genotípicas baseado na constituição alélica do loco marcador e usar correlações estatísticas para determinar se indivíduos de genótipos distintos diferem significativamente entre si em relação ao caráter medido. Se houver diferenças significativas, infere-se que pelo menos um gene que controla 0 caráter está ligado ao loco marcador usado para genotipar a população. $O$ procedimento é então repetido para os locos marcadores distribuídos pelo genoma para detectar tantos QTLs quantos forem possíveis. Normalmente, não é possível determinar se o efeito detectado com um marcador é devido a um ou mais genes ligados que afetam o caráter. Por esta razão, o termo loco de 
caráter quantitativo (QTL) foi usado para descrever uma região do cromossomo (usualmente definida por ligação a um gene marcador) que tem um efeito significativo em um caráter quantitativo. Determinar se um QTL é devido a um ou mais genes é um dos mais difíceis aspectos da genética quantitativa (Tanksley, 1993).

A metodologia mais simples para detectar QTLs é a análise dos dados usando um marcador de cada vez. A análise de marcas simples não exige métodos computacionais complexos e não requer o conhecimento da posição dos marcadores no genoma (Lynch \& Walsh, 1997). Esta análise consiste na comparação entre as médias das classes genotípicas dos marcadores, podendo ser realizada pelo teste $t$, teste de $F$, ou ainda regressão linear. $A$ mesma análise é repetida para cada loco marcador (Bernardo, 2002). Uma desvantagem da análise de marcas simples é o fato de que quanto maior a distância entre o QTL e o marcador, menor a probabilidade de se detectá-lo estatisticamente, devido à possibilidade de recombinação entre o marcador e o QTL. Além disso, a magnitude do efeito do QTL normalmente é subestimada (Tanksley, 1993). Outra desvantagem desta metodologia de análise é a não distinção entre um QTL de pequeno efeito, situado muito próximo ao marcador, de um QTL de grande efeito, situado mais distante (Liu, 1998).

O mapeamento por intervalo estima a localização de um eventual QTL entre pares de marcas adjacentes em um grupo de ligação, ou seja, entre marcadores flanqueando um intervalo (Lander \& Botstein, 1989). Assim, aumenta-se o poder de detecção de QTLs ao longo do genoma e torna-se possível obter uma estimativa mais precisa de seus efeitos no caráter e posicionamento em relação aos marcadores. A maior vantagem da análise por intervalo em comparação com a análise de marcas simples ocorre quando marcadores estão distanciados entre 20 a 35 cM. Nestas condições, provavelmente existirão algumas permutas entre os marcadores e o QTL, que podem ser compensadas pela análise por intervalo. O mapeamento por 
intervalo, entretanto, traz como inconveniente $o$ fato de que a análise é realizada para intervalos considerados isoladamente, estando sujeita a certo nível de ocorrência de falsos positivos em regiões adjacentes às regiões que contêm QTLs (Doerge, 1993, citada por Coelho, 2000). O procedimento envolve o cálculo do LOD score. O valor LOD (logarithm of odds-ratio) indica, na escala logarítmica, a razão entre uma função de verossimilhança que assume a existência de um QTL ligado a um dado marcador sobre uma função que assume a não existência de ligação. Um LOD igual a 3, por exemplo, indica uma probabilidade de existência de um QTL $10^{3}$ vezes maior que a probabilidade de sua ausência (Bernardo, 2002). Outra opção é a utilização da regressão no mapeamento por intervalo que é conceitualmente similar e computacionalmente mais simples que a máxima verossimilhança (Haley \& Knott, 1992). Neste enfoque, o mapeamento por intervalo pode ser estendido para acomodar vários QTLs no mesmo cromossomo (Bernardo, 2002).

A associação entre marcador e QTL também pode ser testada por um modelo de regressão múltipla, incluindo todas as marcas, através de um procedimento de eliminação de variáveis, como o forward, o backward ou o stepwise, para o descarte de marcas não informativas (Silva \& Vencovsky, 2002). Um modelo de regressão múltipla é expresso da seguinte forma:

$$
Y_{i}=\beta_{0}+\beta_{1} X_{1 i}+\beta_{2} X_{2 i}+\ldots+\beta_{k} X_{k i}+e_{i}
$$

em que: $Y_{i}$ é uma variável resposta; $X_{1}, X_{2}, \ldots, X_{k}$ são os locos marcadores (variáveis conhecidas); e $\beta_{0}, \beta_{1}, \beta_{2}, \ldots, \beta_{\mathrm{k}}$ são os efeitos dos locos marcadores (parâmetros desconhecidos).

O fato de uma marca ser descartada do modelo não implica que esta não exerça nenhum efeito no caráter avaliado. O que é testado é se a marca exerce efeito sobre o caráter na presença das demais. Draper \& Smith (1998) apresentam métodos de seleção de variáveis no intuito de permitir que apenas marcas com evidências de estarem ligadas a QTLs fiquem no modelo e evitar a redundância de informação entre elas. O método backward, por exemplo, é um 
algoritmo que inicia o ajustamento com todas as variáveis no modelo. Em seguida, testa a que tem menor valor de $t$ calculado $\left(t_{c}\right)$. Se o teste for não significativo, a variável é retirada do modelo. O processo é repetido até que a variável com menor $t_{c}$ seja significativa e, conseqüentemente, todas as demais também sejam. O método forward parte de um modelo contendo apenas a constante $\beta_{0}$. Inicialmente, a variável com maior $t_{c}$ é testada e, caso seja significativa, entra no modelo. O processo é repetido para as demais variáveis até que, dentre as variáveis fora do modelo, a de maior $t_{c}$ não seja significativa. O método stepwise consiste em um forward, sendo que a cada entrada de uma variável no modelo um processo backward é implementado. Isto é feito com o objetivo de eliminar alguma variável que tenha entrado no modelo em uma etapa anterior e que tenha passado a ser não significativa no passo atual.

O procedimento mais utilizado atualmente para mapear QTLs é o denominado mapeamento por intervalo composto (Zeng, 1993; Jansen, 1993). Esta metodologia combina o mapeamento por intervalo com regressão linear múltipla, no intuito de eliminar a interferência de QTLs adjacentes na análise do intervalo que está sendo mapeado. Além de proporcionar uma maior resolução no mapeamento de QTLs, este tipo de análise permite a utilização de dados obtidos em vários ambientes, de modo que a interação de QTLs com ambientes possa ser avaliada (Coelho, 2000).

O mapeamento por intervalos múltiplos (Kao et al., 1999) considera todos os marcadores ligados em um cromossomo simultaneamente, resultando em uma análise simples para cada cromossomo. Esta metodologia possibilita a avaliação da contribuição dos efeitos epistáticos para a expressão do caráter, tendo como vantagens adicionais a maior eficiência e precisão na identificação de QTLs e, conseqüentemente, maior eficiência da seleção assistida por marcadores (Melo, 2000). 


\subsection{Mapeamento de genes de resistência a doenças em milho}

Genes de resistência podem estar arranjados de diferentes formas no genoma. Locos de resistência podem ser genes simples com múltiplos alelos. Entretanto, a maioria dos genes de resistência pertence a famílias de genes ligados. Em espécies com uma alta densidade gênica, como Arabidopsis e arroz, os genes são fisicamente próximos uns dos outros (Hulbert et al., 2001). Em espécies com uma menor densidade de genes, eles se encontram mais distantes, como é o caso do loco Rp1 de milho (Sun et al., 2000).

O uso de mapas genéticos baseados em marcadores moleculares permite que genes de resistência a vários patógenos sejam mapeados uns em relação aos outros. A partir desses mapas, observou-se que genes dentro de um único cluster (agrupamento) podem determinar resistência a patógenos muito diferentes. Alguns clusters carregam diferentes genes que não são derivados de duplicações recentes, indicando que transposições ou rearranjamentos podem estar envolvidos em sua formação. O cluster pode ser favorecido pela seleção por causa da co-dependência dos genes para o fenótipo resistência (Hulbert et al., 2001).

Agrupamentos de genes de resistência podem ser observados numa escala genômica maior que a de famílias gênicas. Como podem ser observados na Tabela 1, os cromossomos do milho são subdivididos em bins, ou seja, regiões de aproximadamente $20 \mathrm{cM}$ delimitadas por marcadores RFLP de posição conhecida (McMullen \& Simcox, 1995). A localização em bins, por sua vez, permite combinar as informações acerca dos diferentes genes de resistência mapeados na espécie. Agrupamentos de genes de resistência em milho ocorrem em todos os grupos de ligação, com exceção dos cromossomos 7 e 9 (Tabela 1). Estes podem ser encontrados, principalmente, nos bins 1.04, 2.04, 3.04-3.07, 5.02/03, 4.02, 5.02/03, 6.01, 8.06 e 10.01-10.05. É interessante observar que a maior parte dos agrupamentos de genes de resistência 
encontra-se em regiões centroméricas e teloméricas, ou seja, regiões com menor freqüência de recombinação.

A relação funcional entre os genes de resistência dentro de um cluster ainda não foi elucidada, pois apenas os genes Hm1 (Johal \& Briggs, 1992) e Rp1-D (Collins et al., 1999) foram clonados até o momento. As proteínas codificadas pela maioria dos genes de resistência carregam motivos encontrados em outras proteínas receptoras e de transdução de sinais (Hulbert et al., 2001). O gene Hm1, entretanto, é diferente dos demais genes de resistência conhecidos, codificando uma redutase NADP funcional que detoxifica a toxina HC produzida pela raça 1 de Cochliobolus carbonum (Johal \& Briggs, 1992). O gene Rp1-D de resistência a ferrugem comum (Puccinia sorghi) é membro de um loco complexo (loco rp1) composto por aproximadamente oito genes homólogos. $R p 1-D$ pertence a uma classe de genes de resistência que contém um sítio de adesão de nucleotídeos e repetições ricas em leucina (NBS-LRR). Linhagens quase isogênicas para especificidades de rp1 mostraram padrões distintos e complexos de hibridização quando uma sonda $R p 1-D$ foi usada, indicando que estas linhagens contêm múltiplos genes relacionados e proximamente ligados. Análises de recombinantes entre especificidades rp1 indicaram que a recombinação ocorreu dentro do complexo gênico rp1. Portanto, outras especificidades que mapeiam neste loco podem ser codificadas por genes relacionados ao $R P 1-D$. Análises similares indicaram que os genes de resistência no loco rp5, a 2 cM de distância de rp1, não são proximamente relacionados a rp1, apesar de serem membros da classe de genes NBS-LRR (Collins et al., 1999). 
Tabela 1. Genes de resistência e QRLs mapeados em milho

\begin{tabular}{|c|c|c|c|}
\hline Bin & Doença & Loco & Referência \\
\hline 1.01 & $\begin{array}{l}\text { /02 Mancha por Helminthosporium } \\
\text { turcicum }\end{array}$ & QRL & Freymark et al., 1994 \\
\hline 1.03 & Míldio do sorgo em milho & QRL & Agrama, 1999 \\
\hline \multirow{4}{*}{1.04} & Cerposporiose & QRL & Bubeck et al., 1993 \\
\hline & Podridão por Erwinia & QRL & Ming et al., 1995a \\
\hline & Podridão por Erwinia & sw1 & Ming et al., 1999 \\
\hline & Mosaico comum do milho (MSV) & $m s v 1$ & Kyetere et. al.1995 \\
\hline \multirow[t]{2}{*}{1.05} & Mosaico comum do milho (MSV) & QRL & Pernet et al., 1999 \\
\hline & /06 Cerposporiose & QRL & Lehmensiek et al., 2001 \\
\hline 1.06 & /08 Mancha por H. turcicum & QRL & Welz et al., 1999 \\
\hline \multirow[t]{3}{*}{1.07} & Helmintosporiose & $h m 1$ & Coe et al., 1988* \\
\hline & Podridão por Fusarium & QRL & Pè et al., 1993 \\
\hline & Míldio do sorgo em milho & QRL & Agrama, 1999 \\
\hline \multirow[t]{2}{*}{2.03} & Ferrugem comum & QRL & Kerns el al., 1999 \\
\hline & Mosaico comum do milho (MSV) & QRL & Pernet et al., 1999 \\
\hline \multirow[t]{3}{*}{2.04} & Mosaico comum do milho (MSV) & QRL & Pernet et al., 1999 \\
\hline & Ferrugem comum & QRL & Brown et al., 2001 \\
\hline & /05 Cercosporiose & QRL & Bubeck et al., 1993 \\
\hline 2.06 & Mancha por $H$. turcicum & QRL & Welz et al., 1999 \\
\hline 2.08 & Mancha por H. turcicum & $h+1$ & Bentolila et al., 1991 \\
\hline 3.01 & Mancha por $H$. turcicum & QRL & Welz et al., 1999 \\
\hline \multirow[t]{2}{*}{3.03} & /02 Mosaico comum do milho (MSV) & QRL & Pernet et al., 1999 \\
\hline & Mancha por $H$. turcicum & QRL & Welz et al., 1999 \\
\hline \multirow[t]{7}{*}{3.04} & Ferrugem comum & rp3 & Coe et al., $1988^{*}$ \\
\hline & Ferrugem comum & QRL & Brown et al., 2001 \\
\hline & Faixa clorótica das nervuras (MMV) & $m v 1$ & Ming et al., $1995 \mathrm{~b}$ \\
\hline & Mosaico comum do milho (WSMV) & wsm2 & McMullen et al., 1994 \\
\hline & Mosaico comum do milho (SCMV) & scm2 & Xu et al., 1999 \\
\hline & Cercosporiose & QRL & Lehmensiek et al., 2001 \\
\hline & /05 Podridão por Fusarium & QRL & Pè et al., 1993 \\
\hline \multirow[t]{2}{*}{3.07} & Mosaico comum do milho (MSV) & QRL & Pernet et al., 1999 \\
\hline & Mancha por H. turcicum & QRL & Welz et al., 1999 \\
\hline 3.07 & /08 Mancha por H. turcicum & QRL & Freymark et al., 1994 \\
\hline 3.09 & Mosaico comum do milho (MSV) & QRL & Pernet et al., 1999 \\
\hline 4.02 & Cercosporiose & QRL & Bubeck et al., 1993 \\
\hline 4.03 & Mancha por $H$. turcicum & $\begin{array}{l}r p 4 \\
\mathrm{QRL}\end{array}$ & Welz et al. 1999 \\
\hline 4.04 & $\begin{array}{l}\text { Cercosporiose } \\
\text { /05 Podridão por Fusarium }\end{array}$ & $\begin{array}{l}\text { QRL } \\
\text { QRL }\end{array}$ & $\begin{array}{l}\text { Bubeck et al., } 1993 \\
\text { Pè et al } 1993\end{array}$ \\
\hline 4.06 & Mancha por H. turcicum & QRL & Welz et al., 1999 \\
\hline 4.07 & Podridão por Erwinia & QRL & Brown et al., 2001 \\
\hline \multirow[t]{2}{*}{4.08} & Cercosporiose & QRL & Bubeck et al., 1993 \\
\hline & Antracnose de colmo & QRL & Jung et al., 1994 \\
\hline \multirow[t]{2}{*}{5.02} & /01 Mancha por H. turcicum & QRL & Freymark et al., 1994 \\
\hline & Podridão por Fusarium & QRL & Pè et al., 1993 \\
\hline
\end{tabular}


Tabela 1. Genes de resistência e QRLs mapeados em milho

\begin{tabular}{|c|c|c|c|}
\hline Bin & Doença & Loco & Referência \\
\hline & Mosaico comum do milho (MSV) & QRL & Pernet et al., 1999 \\
\hline \multirow[t]{4}{*}{5.03} & Mosaico comum do milho (MSV) & QRL & Pernet et al., 1999 \\
\hline & Podridão por Erwinia & QRL & Brown et al., 2001 \\
\hline & Mancha por $H$. turcicum & QRL & Welz et al., 1999 \\
\hline & 104 Cercosporiose & QRL & Lehmensiek et al., 2001 \\
\hline \multirow[t]{2}{*}{5.04} & Podridão por Fusarium & QRL & Pè et al., 1993 \\
\hline & Mancha por $H$. turcicum & QRL & Welz et al., 1999 \\
\hline \multirow[t]{2}{*}{5.06} & 105 Cercosporiose & QRL & Lehmensiek et al., 2001 \\
\hline & Mancha por $H$. turcicum & QRL & Freymark et al., 1994 \\
\hline \multirow[t]{5}{*}{6.01} & /00 Mosaico comum do milho (SCMV) & scm 1 & Xu et al., 1999 \\
\hline & Mancha por H. maydis & $r h m 1$ & Zaitlin et al., 1993 \\
\hline & Mosaico comum do milho (MDMV) & $m d m 1$ & Simcox et al., 1995 \\
\hline & Mosaico comum do milho (WSMV) & wsm1 & McMullen et al., 1994 \\
\hline & Mosaico comum do milho (MSV) & QRL & Pernet et al., 1999 \\
\hline 6.04 & Podridão por Erwinia & QRL & Brown et al., 2001 \\
\hline 6.05 & /07 Mancha por H. turcicum & QRL & Welz et al., 1999 \\
\hline 7.03 & Mancha por H. turcicum & QRL & Freymark et al., 1994 \\
\hline 8.02 & /03 Mancha por H. turcicum & QRL & Welz et al., 1999 \\
\hline 8.03 & /04 Mancha por H. turcicum & QRL & Freymark et al., 1994 \\
\hline 8.05 & Cercosporiose & QRL & Bubeck et al., 1993 \\
\hline \multirow[t]{2}{*}{8.06} & Mancha por $H$. turcicum & $\begin{array}{l}h t n 1 \\
h t 2\end{array}$ & $\begin{array}{l}\text { Simcox \& Bennetzen, } 1993 \\
\text { Zaitlin et al., } 1992\end{array}$ \\
\hline & Mancha por $H$. turcicum & QRL & Welz et al., 1999 \\
\hline 8.07 & Mosaico comum do milho (MSV) & QRL & Pernet et al., 1999 \\
\hline 9.01 & Míldio do sorgo em milho & QRL & Agrama, 1999 \\
\hline 9.02 & Mancha por $H$. turcicum & QRL & Welz et al., 1999 \\
\hline 9.04 & /05 Helmintosporiose & hm2 & Coe et al., $1988^{*}$ \\
\hline 9.05 & Mancha por $H$. turcicum & QRL & Brown et al., 2001 \\
\hline \multirow[t]{3}{*}{10.01} & Ferrugem comum & rp4 & Coe et al., 1988* \\
\hline & & $\begin{array}{c}r p 1 \\
r p 5 \\
r p 1-G\end{array}$ & \\
\hline & Ferrugem polysora & rpp9 & Coe et al., $1988^{*}$ \\
\hline \multirow[t]{4}{*}{10.05} & Cercosporiose & QRL & Bubeck et al., 1993 \\
\hline & Mosaico comum do milho (WSMV) & wsm3 & McMullen et al., 1994 \\
\hline & Mosaico comum do milho (MSV) & QRL & Pernet et al., 1999 \\
\hline & /06 Podridão por Fusarium & QRL & Pè et al., 1993 \\
\hline
\end{tabular}




\section{MATERIAL E MÉTODOS}

\subsection{Modelo de herança mista para resistência a C. graminicola}

\subsubsection{Genótipos utilizados}

As linhagens homozigóticas utilizadas no presente trabalho pertencem ao programa de melhoramento da empresa Sementes DowAgroSciences Ltda. e foram obtidas por, no mínimo, sete autofecundações. A linhagem DAS22 é suscetível a $C$. graminicola e possui grãos semiduros e alaranjados. Esta linhagem é derivada da população Suwan DMR, desenvolvida na Tailândia a partir de seleção de materiais tropicais de grãos duros do Caribe e materiais dentados Tuxpeño. No Brasil, corresponde à população CMS 05, distribuída pela EMBRAPA Milho e Sorgo. A linhagem resistente, DAS3, é precoce, tem grãos duros e alaranjados, sendo originária da população Suwan-3. Essa população foi obtida através de seleção recorrente da população Suwan-1, desenvolvida nas Filipinas. A linhagem DAS6 é suscetível e a linhagem DAS4 é resistente a $C$. graminicola. Ambas possuem grãos semiduros e alaranjados, sendo derivadas de um mesmo sintético de base genética restrita, composto de linhagens obtidas da população Amarillo Dentado e de uma população do Caribe de grãos duros. Ambas as populações são amplamente utilizadas nos programas públicos e privados da Ásia.

Gerações oriundas dos cruzamentos DAS6 x DAS4, DAS6 × DAS3, DAS22 $\times$ DAS4 e DAS22 $\times$ DAS3 foram obtidas na estação experimental da empresa Sementes DowAgroSciences Ltda., no ano agrícola de 2000/01, em 
Cravinhos-SP. As gerações compreenderam as linhagens genitoras $\left(P_{1}\right.$ e $\left.P_{2}\right)$, $F_{1}, F_{2}$ e retrocruzamentos para ambos os genitores $\left(R C_{1}\right.$ e $\left.R C_{2}\right)$.

\subsubsection{Obtenção do inóculo}

O isolado CRI (Coêlho et al., 2001), proveniente da região de Cristalina (GO), foi cultivado por 20 dias em placas de Petri contendo meio de aveia-ágar (40 $\mathrm{g}$ de farinha de aveia, $17 \mathrm{~g}$ de ágar, $1 \mathrm{~L}$ de água destilada) e mantido numa câmara de crescimento a $22 \pm 2^{\circ} \mathrm{C}$, sob lâmpadas fluorescentes, em regime de 12 horas de luz e 12 horas de escuro. A suspensão de inóculo foi obtida pela adição de $20 \mathrm{~mL}$ de água destilada em cada placa de Petri. Com o auxílio de um pincel, procedeu-se a raspagem superficial da cultura, para liberação dos conídios. A suspensão de conídios foi filtrada através de dupla camada de gaze, a fim de separar conídios do micélio e fragmentos de meio de cultura. Com o auxílio de uma câmara de Neubauer, a suspensão foi ajustada à concentração de $5 \times 10^{5}$ conídios $/ \mathrm{mL}$. A cada litro da suspensão adicionou-se uma gota de espalhante adesivo Tween $80^{\circledR}$.

\subsubsection{Avaliação da reação a C. graminicola em quatro cruzamentos}

Dois experimentos foram instalados na estação experimental da empresa Sementes DowAgroSciences Ltda., em Jardinópolis, SP, em 14/11/2001 (época normal de plantio) e em 19/12/2001 (plantio tardio). O delineamento experimental utilizado foi o de blocos casualizados com parcelas subdivididas, com 3 repetições, sendo as parcelas constituídas pelos quatro cruzamentos e as subparcelas pelas gerações parentais $\left(P_{1}\right.$ e $\left.P_{2}\right), F_{1}, F_{2}, R C_{1}$ e $\mathrm{RC}_{2}$ de cada cruzamento. As subparcelas consistiram de uma linha para as linhagens genitoras e gerações $F_{1}$, duas linhas para os retrocruzamentos e 
quatro linhas para as gerações $F_{2}$. Cada linha de $5 \mathrm{~m}$ foi constituída de 25 plantas com espaçamento de 0,20 m entre plantas e 0,80 m entre linhas.

Duas inoculações foram realizadas em ambos os experimentos ulilizando o isolado CRI, aos vinte e vinte e sete dias após a semeadura. As inoculações foram feitas no final da tarde mediante pulverização de aproximadamente $5 \mathrm{~mL}$ da suspensão ( $5 \times 10^{5}$ conídios $/ \mathrm{mL}$ ) no cartucho de cada planta. Nos dias das inoculações, os experimentos foram irrigados no período da manhã para proporcionar uma condição mais favorável à germinação dos conídios. O inóculo foi preparado conforme relatado no item 3.1.2.

As avaliações foram feitas na folha sintomática mais jovem, que geralmente correspondeu à sétima, dezesseis dias após a segunda inoculação. Uma escala de notas de 1 a 6 foi utilizada para a avaliação da doença (Tabela 2).

Tabela 2. Escala de notas baseada no tipo de lesão causada por Colletotrichum graminicola em folhas de milho (adaptada de Silva et al., 1986)

\begin{tabular}{ll}
\hline Nota & Descrição \\
\hline 1 & Ausência de sintomas. \\
2 & $\begin{array}{l}\text { Pontos cloróticos ou necróticos de até } 3 \mathrm{~mm} \text { de comprimento, } \\
\text { com formato circular a oval e ausência de esporulação. }\end{array}$ \\
3 & $\begin{array}{l}\text { Lesões necróticas de } 3 \text { a } 10 \mathrm{~mm} \text { de comprimento, com formato } \\
\text { oval a alongado e pouca esporulação. } \\
4\end{array}$ \\
Lesões necróticas de 10 a $40 \mathrm{~mm}$ de comprimento, com formato \\
alongado ou irregular e pouca esporulação. \\
Lesões necróticas de 40 a $60 \mathrm{~mm}$ de comprimento, com formato \\
alongado ou irregular e esporulação do patógeno. \\
Coalescência de lesões necróticas acima de 60 mm de \\
comprimento e abundante esporulação.
\end{tabular}




\subsubsection{Análises estatísticas}

\subsubsection{Análises de variância}

Análises de variância para severidade média foram realizadas para cada experimento segundo o modelo estatístico:

$$
Y_{i j k}=m+b_{j}+f_{i}+(b f)_{i j}+g_{k(i)}+e_{i j k}
$$

em que:

$Y_{\mathrm{ijk}}$ : severidade média observada na geração $\mathrm{k}$ da cruzamento i na repetição j;

$\mathrm{m}$ : média geral do experimento;

$b_{j}$ : efeito do bloco $j$, sendo $j=1,2,3$;

$f_{i}$ : efeito do cruzamento $i$, sendo $i=1,2,3,4$;

$(\mathrm{bf})_{\mathrm{ij}}$ : erro experimental da parcela (erro a);

$g_{k(i)}$ : efeito da geração $k$ dentro do cruzamento $i$, sendo $k=1,2, \ldots, 6$;

$e_{\mathrm{ijk}}$ : erro experimental da subparcela (erro b).

Para a análise conjunta das duas épocas utilizou-se o seguinte modelo:

$$
Y_{i j k l}: m+p_{l}+f_{i}+b_{j(l)}+(p f)_{l i}+(b f)_{i j}+g_{k(i)}+(g p)_{k(i)}+e_{i j k l}
$$

em que:

$Y_{\mathrm{ijkl}}$ : severidade média observada na geração $\mathrm{k}$, do cruzamento $\mathrm{i}$, na repetição j, na época l;

$\mathrm{m}$ : média geral do experimento;

$p_{1}$ : efeito do experimento $I$, sendo $l=1,2$.

$f_{i}$ : efeito do cruzamento $i$, sendo $i=1,2,3,4$;

$b_{j(I)}$ : efeito do bloco $j$, dentro do experimento I, sendo $j=1,2,3$; 
(pf)|i: efeito da interação do cruzamento i com o experimento l;

$(\mathrm{bf})_{\mathrm{ij}}$ : erro experimental da parcela (erro a);

$g_{k(i)}$ : efeito da geração $k$, dentro do cruzamento i, sendo $k=1,2, \ldots, 6$.

$(\mathrm{gp})_{\mathrm{k}(\mathrm{i})}$ : efeito da interação da geração $\mathrm{k}$ com o experimento $\mathrm{I}$, dentro do cruzamento i;

$e_{\mathrm{ijk} \mid}$ : erro experimental da subparcela (erro b).

\subsubsection{Modelos genéticos e testes de hipóteses}

As estimativas de parâmetros genéticos e testes de hipóteses relativas aos parâmetros foram realizadas pelo Software Monogen v. 0.1 (Silva, 2003). Para a realização das análises, considerou-se como modelo genético mais completo aquele que apresenta um gene de efeito maior, com efeito aditivo e de dominância, e poligenes, também com efeitos aditivos e de dominância. Admitiram-se variâncias ambientais $\left(\sigma^{2}\right)$ iguais em todas as gerações e segregação independente de genes. Segundo este modelo, os valores genotípicos do gene de efeito maior correspondente aos homozigotos e ao heterozigoto são representados, respectivamente, por $\mu-A, \mu+A$ e $\mu+D$, sendo $\mu$ uma constante de referência, $A$ o efeito aditivo do gene maior e $D$ o efeito de dominância do gene maior. Os componentes de média e variância dos poligenes, segundo Mather \& Jinks (1971), estão apresentados na Tabela 3.

A partir do modelo genético completo (modelo 1, Tabela 4) foram gerados modelos mais simples, ou seja, contendo menos parâmetros (modelos 2 a 9 , Tabela 4). As estimativas dos parâmetros genéticos dos modelos foram obtidas pelo método da máxima verossimilhança. Testes de hipóteses sobre os parâmetros genéticos foram realizados pela razão de verossimilhança (LR) entre dois modelos (Mood et al., 1974). A estatística LR testa se um parâmetro adicionado a um modelo leva a um aumento significativo na quantidade de variação explicada pelo mesmo. De maneira geral, LR é dada por: 


$$
L R=-2 \ln \frac{L\left(M_{i}\right)}{L\left(M_{j}\right)}
$$

em que $L\left(M_{i}\right)$ e $L\left(M_{j}\right)$ são funções de verossimilhança dos modelos i e j, sendo o modelo i hierárquico ao modelo j. Esta estatística segue uma distribuição aproximadamente de qui-quadrado em que, para um teste com probabilidade $\alpha$, $\mathrm{H}_{0}$ é rejeitada se $L R>\chi_{(1-\alpha, v)}^{2}$,em que v é o número de graus de liberdade dado pela diferença entre os números de parâmetros dos modelos $M_{j}$ e $M_{i}$.

Tabela 3. Gerações e respectivos componentes poligênicos da média e da variância

\begin{tabular}{ccc}
\hline Geração & $\begin{array}{c}\text { Componente poligênico } \\
\text { da média }\end{array}$ & $\begin{array}{c}\text { Componente poligênico } \\
\text { da variância }\end{array}$ \\
\hline $\mathrm{P} 1$ & $-[\mathrm{a}]$ & - \\
$\mathrm{P} 2$ & {$[\mathrm{a}]$} & - \\
$\mathrm{F}_{1}$ & {$[\mathrm{~d}]$} & - \\
$\mathrm{F}_{2}$ & $1 / 2[\mathrm{~d}]$ & $\mathrm{V}_{\mathrm{A}}+\mathrm{V}_{\mathrm{D}}$ \\
$R C_{1}$ & $-1 / 2[\mathrm{a}]+1 / 2[\mathrm{~d}]$ & $1 / 2 \mathrm{~V}_{\mathrm{A}}+\mathrm{V}_{\mathrm{D}}-\mathrm{S}_{\mathrm{AD}}$ \\
$\mathrm{RC}_{2}$ & $1 / 2[\mathrm{a}]+1 / 2[\mathrm{~d}]$ & $1 / 2 \mathrm{~V}_{\mathrm{A}}+\mathrm{V}_{\mathrm{D}}+\mathrm{S}_{\mathrm{AD}}$ \\
\hline
\end{tabular}

[a]: componente poligênico aditivo; [d]: componente poligênico de dominância; $\mathrm{V}_{\mathrm{A}}$ : variância aditiva; $\mathrm{V}_{\mathrm{D}}$ : variância de dominância; $\mathrm{S}_{\mathrm{AD}}$ : soma dos produtos dos efeitos aditivos e dominantes

Considerando a hierarquização dos modelos, inicialmente confrontaramse os modelo 1 e 5 , sendo o modelo 5 hierárquico ao modelo 1 (Tabela 4). A LR entre estes modelos testa a hipótese de herança monogênica. Em seguida, confrontaram-se os modelos 1 e 7 , sendo o modelo 7 hierárquico ao modelo 1 , para testar a hipótese de herança poligênica. A não significância de um ou ambos os testes implica em aceitar a hipótese de nulidade referente ao teste em questão, ou seja, não evidência de gene de efeito maior, no primeiro caso, e não evidência de poligenes, no segundo caso. Nos casos em que a hipótese de nulidade para LR entre os modelos 1 e 5 tenha sido rejeitada, testaram-se os efeitos de dominância do gene de efeito maior confrontando-se o modelos 7 e o 
modelo 8 , sendo o modelo 8 hierárquico ao modelo 7. Nos casos em que a hipótese de nulidade para LR entre os modelos 1 e 7 tenha sido rejeitada, testaram-se os efeitos de dominância dos poligenes confrontando-se os modelo 5 e 6 , sendo o modelo 6 hierárquico ao modelo 5 . O modelo selecionado para explicar a herança da resistência foi o que incluiu todos os efeitos genéticos significativos.

Tabela 4. Modelos de herança genética e seus parâmetros na análise das gerações $P_{1}, P_{2}, F_{1}, F_{2}, R C_{1}$ e $R C_{2}$

\begin{tabular}{lccl}
\hline Modelo & Gene maior & Poligenes & \multicolumn{1}{c}{ Parâmetros genéticos } \\
\hline 1. Herança mista & adit. e dom. & adit. e dom. & $\mu, A, D,[a],[d], V_{A}, V_{D}, S_{A D}, \sigma^{2}$ \\
2. Herança mista & adit. e dom. & aditivo & $\mu, A, D,[a], V_{A}, \sigma^{2}$ \\
3. Herança mista & aditivo & adit. e dom. & $\mu, A,[a],[d], V_{A}, V_{D}, S_{A D}, \sigma^{2}$ \\
4. Herança mista & aditivo & aditivo & $\mu, A,[a], V_{A}, \sigma^{2}$ \\
5. Poligênica & - & adit. e dom. & $\mu,[a],[d], V_{A}, V_{D}, S_{A D}, \sigma^{2}$ \\
6. Poligênica & - & aditivo & $\mu,[a], V_{A}, \sigma^{2}$ \\
7. Monogênica & adit. e dom. & - & $\mu, A, D, \sigma^{2}$ \\
8. Monogênica & aditivo & - & $\mu, A, \sigma^{2}$ \\
9. Sem efeito & - & - & $\mu, \sigma^{2}$ \\
genético & & &
\end{tabular}

$\mu$ : média do cruzamento; A: efeito aditivo do gene de efeito maior; D: efeito de dominância do gene de efeito maior; [a]: efeito aditivo dos poligenes; [d]: efeito de dominância dos poligenes; $\mathrm{V}_{\mathrm{A}}$ : variância aditiva dos poligenes; $\mathrm{V}_{\mathrm{D}}$ : variância de dominância dos poligenes; $S_{A D}$ : soma dos produtos dos efeitos aditivos e dominantes; $\sigma^{2}$ : variância ambiental

Foram estimadas as herdabilidades no sentido amplo $\left(\hat{h}_{a}^{2}\right)$ e restrito $\left(\hat{h}_{r}^{2}\right)$ pelas seguintes fórmulas:

$$
\begin{aligned}
& \hat{h}_{a}^{2}=\frac{V_{A}+V_{D}+A^{2} / 2+D^{2} / 4}{V_{A}+V_{D}+A^{2} / 2+D^{2} / 4+\sigma^{2}} \\
& \hat{h}_{r}^{2}=\frac{V_{A}+A^{2} / 2}{V_{A}+V_{D}+A^{2} / 2+D^{2} / 4+\sigma^{2}}
\end{aligned}
$$




\subsection{Mapeamento de genes de resistência a C. graminicola}

\subsubsection{População de mapeamento}

Foram utilizados 141 indivíduos $\mathrm{F}_{1} \mathrm{RC}_{1}$ provenientes do cruzamento (DAS6 x DAS4) x DAS6. A descrição das linhagens encontra-se no item 3.1.1. As avaliações fenotípicas foram realizadas nas respectivas famílias $F_{1: 2} R C_{1}$.

A população $F_{1} R C_{1}$ foi desenvolvida na estação experimental da empresa Sementes DowAgroSciences Ltda., em Cravinhos, SP. Já as famílias $F_{1: 2} R C_{1}$ foram obtidas no campo experimental da Seção de Fitopatologia da ESALQUSP.

\subsubsection{Avaliação da reação a Colletotrichum graminicola em famílias $\mathrm{F}_{1: 2} \mathbf{R C}_{1}$}

As 141 famílias $F_{1: 2} R C_{1}$, as linhagens genitoras e o híbrido foram avaliados na estação experimental da empresa DowAgroSciences, em Jardinópolis-SP, em dois experimentos instalados em 14/11/2001 (época normal de plantio) e 19/12/2001 (plantio tardio). O delineamento experimental utilizado foi o látice $12 \times 12$, com 3 repetições. A parcela foi constituída por uma linha de quatro metros, com cinco plantas por metro, e espaçamento de 0,20 m entre plantas e 0,80 m entre linhas.

Em cada experimento, duas inoculações foram realizadas com o isolado $\mathrm{CRI}$, aos vinte e vinte e sete dias após a semeadura. As inoculações foram feitas no final da tarde mediante pulverização de aproximadamente $5 \mathrm{~mL}$ de inóculo ( $5 \times 10^{5}$ conídios $/ \mathrm{mL}$ ) no cartucho de cada planta. Nos dias das inoculações, os experimentos foram irrigados no período da manhã para proporcionar uma condição mais favorável à germinação dos conídios. O inóculo foi preparado conforme relatado no item 3.1.2. 
As avaliações foram feitas na folha sintomática mais jovem, geralmente a sétima, dezesseis dias após a segunda inoculação. Uma escala de notas de 1 a 6 foi utilizada para a avaliação da doença (Tabela 2). Foram avaliadas dez plantas dentro de cada parcela.

Utilizou-se a nota média da parcela para a análise de variância nas duas épocas, obedecendo-se o modelo estatístico:

$$
Y_{i j k}=m+t_{i}+r_{j}+b_{k(j)}+e_{i j k}
$$

em que:

$\mathrm{Y}_{\mathrm{ijk}}$ : valor observado na parcela que recebeu o tratamento $\mathrm{i}$, no bloco $\mathrm{k}$, dentro da repetição j;

$\mathrm{m}$ : média geral;

$t_{i}$ : efeito do tratamento $i$, sendo $i=1,2, \ldots, 144$;

$r_{j}$ : efeito da repetição $j$, sendo $j=1,2,3$;

$b_{k(j)}$ : efeito do bloco incompleto $k$ dentro da repetição $j$, sendo $k=1,2, \ldots, 12$;

$e_{i j k}$ : erro experimental associado a observação $Y_{i j k}$.

Constatada a homogeneidade de variância dos erros dos dois experimentos, procedeu-se a análise conjunta, segundo o modelo estatístico:

$$
Y_{i j k l}=m+t_{i}+l_{j}+r_{k(j)}+b_{l(k, l)}+\left.t_{i j}\right|_{j}+e_{i j k l}
$$

em que:

$\mathrm{Y}_{\mathrm{ijkl}}$ : valor observado na parcela que recebeu o tratamento $\mathrm{i}$, no bloco $\mathrm{k}$, dentro da repetição j;

$\mathrm{m}$ : média geral;

$t_{i}$ : efeito do tratamento $i$, sendo $i=1,2, \ldots, 144$;

$\mathrm{I}_{\mathrm{j}}$ : efeito do experimento $\mathrm{j}$, sendo $\mathrm{j}=1,2$; 
$r_{k(j)}$ : efeito da repetição $k$ dentro do experimento j, sendo $k=1,2,3$;

$b_{((k,))}$ : efeito do bloco incompleto I dentro da repetição $k$ e do experimento $j$, sendo $\mathrm{I}=1,2, \ldots, 12$;

$\mathrm{t}_{\mathrm{i} j \mathrm{j}}$ : efeito da interação entre tratamento i e experimento j;

$e_{i j \mathrm{jl}}$ : erro experimental associado a observação $Y_{\mathrm{ijk} \mid}$.

Estimativas dos componentes de variância genética entre famílias $\left(\hat{\sigma}_{\mathrm{P}}^{2}\right)$ foram obtidas da seguinte forma:

$$
\begin{aligned}
& V(M A j){ }^{*} r \cong \hat{\sigma}^{2}+r \hat{\sigma}_{P}^{2} \\
& \hat{\sigma}_{P}^{2}=\frac{V(M A j){ }^{*} r-\hat{\sigma}^{2}}{r}=V(M A j)-\frac{\hat{\sigma}^{2}}{r}
\end{aligned}
$$

em que:

V(MAj): variância das médias ajustadas das famílias;

r: número de repetições;

$\hat{\sigma}^{2}$ : variância ambiental (QMErro);

As herdabilidades entre médias de famílias $\left(\hat{\mathrm{h}}^{2}\right)$, no sentido amplo, foram estimadas segundo Vencovsky e Barriga (1992), onde:

$$
\hat{h}_{\mathrm{a}}^{2}=\frac{\hat{\sigma}_{\mathrm{P}}^{2}}{\frac{\hat{\sigma}^{2}}{r}+\hat{\sigma}_{\mathrm{P}}^{2}}
$$

Também foi possível estimar o coeficiente de variação genético $\left(\mathrm{CV}_{\mathrm{g}}\right)$ e 0 coeficiente b, pelas expressões (Vencovsky e Barriga, 1992): 


$$
\begin{aligned}
& \mathrm{CV}_{\mathrm{g}}=\frac{100 \sqrt{\hat{\sigma}_{\mathrm{P}}^{2}}}{\mathrm{~m}} \\
& \mathrm{~b}=\frac{\mathrm{CV}_{\mathrm{g}}}{\mathrm{CV}_{\mathrm{e}}}
\end{aligned}
$$

\subsubsection{Genotipagem com marcadores moleculares}

\subsubsection{Extração e quantificação de DNA}

A extração de DNA das plantas $F_{1} R C_{1}$ que originaram as famílias avaliadas no item 3.2.2, bem como de plantas híbridas e parentais foi realizada utilizando protocolo semelhante ao descrito por Hoisington et al. (1994), modificada para tubos "eppendorf" de 1,5 mL. Folhas armazenadas em ultrafreezer $\left(-80^{\circ} \mathrm{C}\right)$ foram maceradas em almofariz com auxílio de um pistilo na presença de nitrogênio líquido. O tecido macerado foi colocado em tubos "eppendorf" de 1,5 mL, preenchendo aproximadamente um terço do volume total. Foram adicionados $600 \mu \mathrm{L}$ do tampão de extração $1 \%$ CTAB $(70 \mu \mathrm{M}$ da $\mathrm{NaCl} ; 50 \mu \mathrm{M}$ de EDTA pH 8,0; $100 \mu \mathrm{M}$ Tris- $\mathrm{HCl}$ pH 7,5; 1\% p/v de CTAB e 140 $\mu \mathrm{M}$ de $\beta$-mercaptoetanol) previamente aquecido a $65^{\circ} \mathrm{C}$. A seguir, as amostras foram incubadas em banho-maria a $65^{\circ} \mathrm{C}$, por uma hora, sendo agitadas levemente a cada 10 minutos. Após esse tempo, adicionou-se o mesmo volume de clorofórmio/álcool-isoamílico (CIA) (24:1), efetuando-se leve agitação, seguida de centrifugação por 12 minutos a 12.400 rpm. Após a centrifugação, o sobrenadante foi transferido para novos tubos, sendo repetida a extração com CIA 24:1. O sobrenadante foi transferido para novos tubos, aos quais foi adicionado o mesmo volume de álcool etílico absoluto gelado. Após inversão dos tubos por várias vezes, os mesmos foram centrifugados para precipitação do DNA, descartando-se o sobrenadante em seguida. O "pellet" foi lavado com etanol $75 \%$ por 2 minutos, etanol $90 \%$ por 2 minutos e etanol absoluto por 1 
minuto. Após secagem à temperatura ambiente, o DNA foi ressuspendido em $50 \mu \mathrm{L}$ de TE $\mathrm{pH} 8,0$ (10mM de Tris-HCl e $1 \mathrm{mM}$ de EDTA) e transferido para tubos "eppendorf" de 0,5 mL. Após 12 horas, adicionou-se $1 \mu \mathrm{L}$ de RNAse $(1 \mathrm{mg} / \mathrm{ml})$ ao DNA ressuspendido, incubando-se a $37^{\circ} \mathrm{C}$ por $2 \mathrm{~h}$. Em seguida, a suspensão de DNA foi armazenada a $4^{\circ} \mathrm{C}$ até o momento do uso.

A concentração de DNA foi estimada através de fluorímetro (Hoefer DyNA Quant 200). A integridade do DNA foi avaliada por eletroforese em gel de agarose $1 \%$, o qual foi corado com brometo de etídeo $(10 \mathrm{mg} / \mathrm{mL})$, visualizado sob luz ultravioleta e fotodocumentado com o aparelho ImageMaster VDS (Pharmacia Biotech). Com base na concentração de DNA estimada, procedeuse a diluição das amostras para uma concentração de $10 \mathrm{ng} / \mu \mathrm{L}$.

\subsubsection{Genotipagem com marcadores microssatélites}

Inicialmente 165 microssatélites (SSR) foram analisados nos genitores para identificar polimorfismos. Os SSR polimórficos entre genitores foram analisados em dois bulks de DNA, compostos de quantidades equimolares de DNA de 10 indivíduos resistentes e de 10 indivíduos suscetíveis da população $F_{1} R C_{1}$. Posteriormente, 141 indivíduos da população $F_{1} R C_{1}$ foram genotipados com aproximadamente dois primers SSR por cromossomo, utilizando o protocolo de Senior et al. (1996) com algumas modificações. As reações foram feitas em volume final de $20 \mu \mathrm{L}$, contendo $30 \mathrm{ng}$ de DNA, $2 \mu \mathrm{L}$ de tampão $10 \mathrm{X}$ (200 mM de Tris- $\mathrm{HCl}$, pH 8,4; $500 \mathrm{mM}$ de $\mathrm{KCl}$ ), 2,25 mM MgCl $2,0,1 \mathrm{mM}$ de cada dNTP, 0,5 $\mu \mathrm{M}$ de primer anverso, 0,5 $\mu \mathrm{M}$ de primer reverso e 0,75 unidades de Taq DNA polimerase (Promega) e água ultrapura autoclavada para completar o volume. Para evitar evaporação da reação durante a amplificação, cada amostra recebeu uma gota de óleo mineral Nujol. As reações foram realizadas em termocicladores PTC-100 (M.J. Research, Inc.), os quais foram programados para um passo inicial de desnaturação a $94^{\circ} \mathrm{C}$ por 3 minutos, 
seguido por um primeiro estágio no qual a temperatura inicial de hibridização foi reduzida em $1^{\circ} \mathrm{C}$ a cada 2 ciclos até atingir a temperatura de $55^{\circ} \mathrm{C}\left(65^{\circ} \mathrm{C}-55^{\circ} \mathrm{C}\right)$. O segundo estágio consistiu em 19 ciclos de amplificação no qual a menor temperatura de hibridização $\left(55^{\circ} \mathrm{C}\right)$ permaneceu constante. Passos de desnaturação e elongação foram de 1 minuto a $94^{\circ} \mathrm{C}$ e 2 minutos a $72^{\circ} \mathrm{C}$, respectivamente em ambos os estágios. Um passo de elongação final a $72^{\circ} \mathrm{C}$ por 6 minutos foi realizado após o segundo estágio (Ogliari et al., 2000).

Após a amplificação, cada amostra recebeu $4 \mu \mathrm{L}$ de tampão de carregamento (azul de bromofenol 0,25\%, sacarose $40 \%$ ). Os produtos da amplificação foram resolvidos em gel de agarose (Life Technologies) 3,5\%, preparado com tampão TBE $1 \mathrm{X}$ (Tris-borato 0,09 M; EDTA 2,0 mM) a aproximadamente 3 volts $/ \mathrm{cm}$. Logo após a eletroforese, os géis foram corados em solução de brometo de etídio, visualizados em transiluminador de luz ultravioleta e registrados em aparelho fotodocumentador Image Master VDS (Pharmacia Biotech).

\subsubsection{Genotipagem com marcadores AFLP}

O DNA dos genitores e dos bulks segregantes foi analisado com 89 combinações de primers AFLP. Posteriormente, a população $F_{1} R C_{1}$ foi analisada com primers que apresentaram polimorfismos entre bulks.

O protocolo de amplificação foi adaptado do descrito por S. Hazen e R.W. Ward (http://www.msu.edu/user/hazensam/aflp/AFLPprotocolMSU.html). A digestão do DNA foi feita através de uma combinação de duas enzimas, sendo uma de corte freqüente $(M s e \mathrm{I})$ e uma de corte raro $(E c o R \mathrm{I})$. Para cada reação foram utilizados $300 \mathrm{ng}$ de DNA genômico, 5,0 $\mu \mathrm{L}$ de tampão One Phor All 10X (Amersham), 0,5 $\mu \mathrm{L}$ de solução BSA (10 $\mu \mathrm{g} / \mu \mathrm{L}$ ), 1,25 $\mu \mathrm{L}$ da enzima Mse I (4 unidades $/ \mu \mathrm{L} ;$ New England Biolabs) e $0,5 \mu \mathrm{L}$ da enzima EcoR I (10 unidades/ $\mu \mathrm{L}$; Gibco). Esta mistura de reagentes, cujo volume final foi 
completado para $50 \mu \mathrm{L}$ com água ultrapura autoclavada, foi incubada a $37^{\circ} \mathrm{C}$ por 3 horas, sendo cuidadosamente agitada a intervalos de uma hora. Após a digestão, as enzimas foram inativadas a $70^{\circ} \mathrm{C}$ durante 15 minutos. Para verificar o resultado da digestão, $10 \mu \mathrm{L}$ da reação de digestão foram submetidos à eletroforese em gel de agarose $1 \%$ por 3 horas em tampão TBE $1 \mathrm{X}(2,5 \mathrm{~V} / \mathrm{cm})$. Após a corrida, os géis foram corados com brometo de etídeo $(0,5 \mu \mathrm{g} / \mathrm{mL})$ durante 15 minutos e posteriormente fotografados sob luz UV.

Os adaptadores foram preparados em quantidade suficiente para ligações de 120 amostras. Para o preparo do adaptador $E c o R I$ foram utilizados 3,4 $\mu \mathrm{L}(1 \mu \mathrm{g} / \mu \mathrm{L})$ de adaptador EcoR I oligo 1 (5'CTCGTAGACTGCGTACC3'), $3,0 \mu \mathrm{L}(1 \mu \mathrm{g} / \mu \mathrm{L})$ de adaptador EcoR I oligo 2 (ATT TGG TAC GCA GTC TAC), 6,0 $\mu \mathrm{L}$ de tampão de OPA (One Phor All, Amersham) e 107,6 $\mu \mathrm{L}$ de água ultrapura. No preparo do adaptador Mse I foram utilizados $32,0 \mu \mathrm{L}(1,0 \mu \mathrm{g} / \mu \mathrm{L})$ de adaptador Mse I oligo 1 (5'GACGATGAG TCCTGAG3'), 28,0 $\mu \mathrm{L}(1,0 \mu \mathrm{g} / \mu \mathrm{L})$ de adaptador Mse I oligo 2 (5'TACTCAGGACTCAT3'), 7,0 $\mu \mathrm{L}$ do tampão OPA e 53,0 $\mu \mathrm{L}$ de água ultrapura. As reações de hibridização das fitas foram realizadas em termociclador utilizando o seguinte programa: $65^{\circ} \mathrm{C}$ por 10 minutos, $37{ }^{\circ} \mathrm{C}$ por 10 minutos e $25^{\circ} \mathrm{C}$ por 10 minutos. Após seu preparo, os adaptadores foram armazenados a $-20^{\circ} \mathrm{C}$.

Os adaptadores foram ligados aos fragmentos de DNA em uma reação contendo 2,0 $\mu \mathrm{L}$ do tampão da enzima T4 DNA ligase 5X (Invitrogen), 1,0 $\mu \mathrm{L}$ de adaptador EcoR I, 1,3 $\mu \mathrm{L}$ de adaptador Mse I , $1 \mu \mathrm{L}$ de T4 DNA ligase (1 unidade/ $\mu \mathrm{L}$, Invitrogen), $4,7 \mu \mathrm{L}$ de água ultrapura e $40 \mu \mathrm{L}$ de DNA digerido. As reações de ligação foram realizadas a $20^{\circ} \mathrm{C}$ por 3 horas, sendo cuidadosamente agitadas a intervalos de 40 minutos. Em seguida, foram armazenadas a $-20^{\circ} \mathrm{C}$.

Os fragmentos de DNA foram amplificados em duas reações. $\mathrm{Na}$ primeira, denominada reação de pré-amplificação, foram utilizados primers EcoR I e Mse I, com extensão de 1 nucleotídeo seletivo na extremidade 3'. O 
produto da reação de pré-amplificação foi diluído e utilizado como molde na segunda reação, denominada amplificação seletiva. Nesta, foram utilizados 3 nucleotídeos seletivos adicionados à extremidade 3' dos primers, sendo o primeiro nucleotídeo correspondente ao utilizado na pré-amplificação (Tabela $5)$.

Tabela 5. Sequências dos adaptadores e dos primers usados na préamplificação e amplificação seletiva.

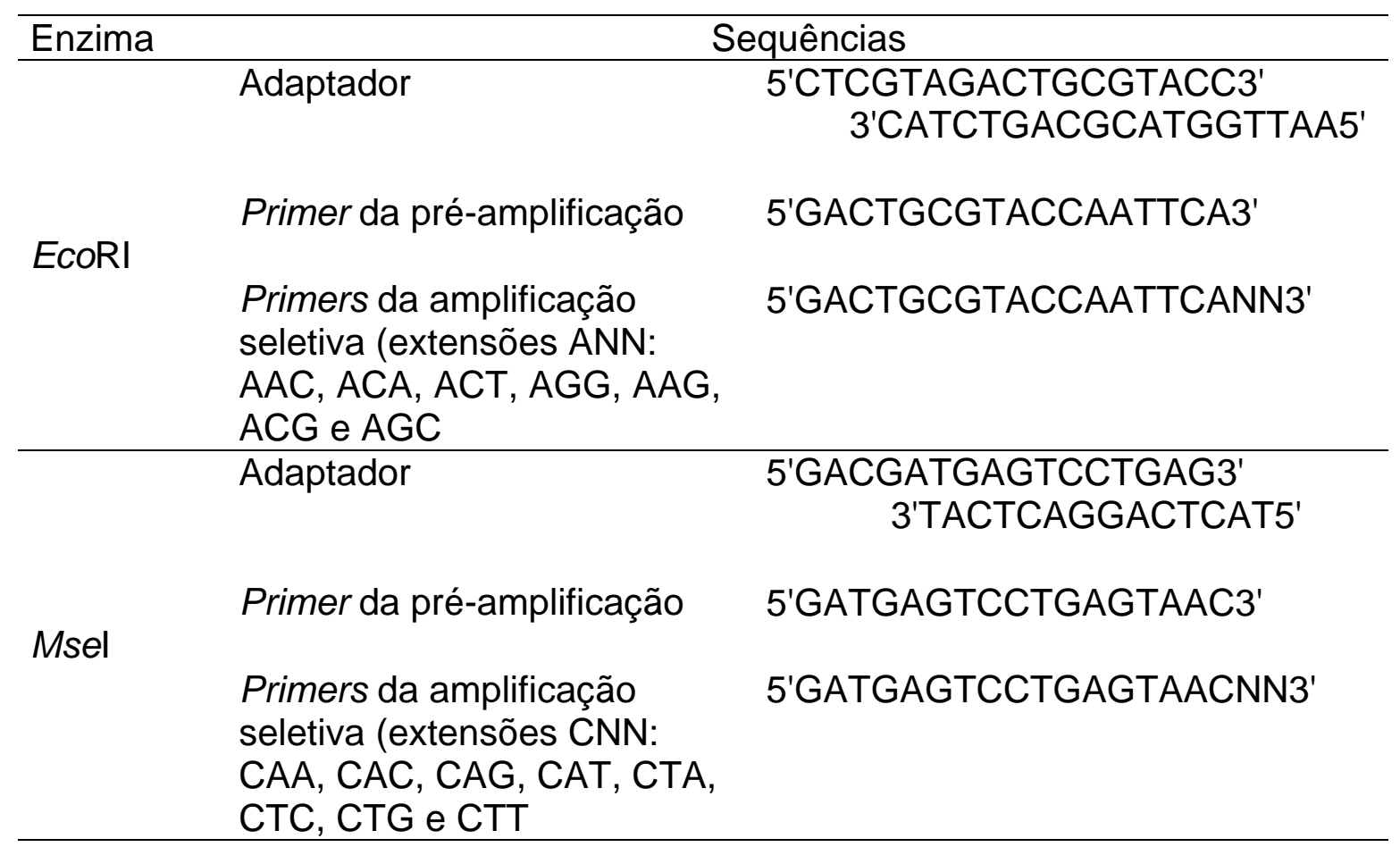

As reações de pré-amplificação foram compostas por 1,0 $\mu \mathrm{L} E c o R I+\mathrm{A}$ (25 ng/ $\mu \mathrm{L}), 1,0 \mu \mathrm{L}$ Mse I + C (25 ng/ $\mu \mathrm{L}), 0,8 \mu \mathrm{L}$ de dNTP $10 \mathrm{mM}$ (Gibco), 2,0 $\mu \mathrm{L}$ de tampão Mg Free Buffer 10X (Promega), 1,2 $\mu \mathrm{L} \mathrm{MgCl}_{2} 25 \mathrm{mM} ; 0,6 \mu \mathrm{L}$ de Taq DNA polimerase (5,0 unidades/ $\mu \mathrm{L}$; Promega), $11,4 \mu \mathrm{L}$ de água ultrapura e $2 \mu \mathrm{L}$ da amostra de DNA digerido e ligado. O programa de pré-amplificação foi composto de 26 ciclos de amplificação, após desnaturação inicial a 94ํㅡ por 2 minutos. Cada ciclo foi constituído de 1 minuto a $94^{\circ} \mathrm{C}$ (desnaturação), 1 minuto 
a $56^{\circ} \mathrm{C}$ (hibridização) e 1 minuto a $72^{\circ} \mathrm{C}$ (extensão). O ciclo final foi de $72^{\circ} \mathrm{C}$ por 5 minutos. Ao produto da reação foram adicionados $80 \mu \mathrm{L}$ de água ultrapura, sendo armazenado a $-20^{\circ} \mathrm{C}$.

Nas reações de amplificação seletiva foram utilizadas combinações de primers EcoR I com Mse I, sendo ambos com extensão de 3 pares de bases adicionados ao adaptador na extremidade 3'. Os primers são representados por $E c o R I+A N N$ e Mse I + CNN, sendo $\mathrm{N}$ os nucleotídeos seletivos adicionados à extremidade 3' do primer (Tabela 5). As reações foram preparadas com 1,0 $\mu \mathrm{L}$ (25 ng/ $\mu \mathrm{L})$ de primer EcoR I + ANN, 1,2 $\mu \mathrm{L}(25 \mathrm{ng} / \mu \mathrm{L})$ de primer Mse I + CNN, 0,4 $\mu \mathrm{L}$ de dNTP 10mM (Gibco), 2,0 $\mu \mathrm{L}$ de tampão da Taq polimerase 10X (Promega), 1,2 $\mu \mathrm{L}$ de $\mathrm{MgCl}_{2} 25 \mathrm{mM}$ (Promega), 0,2 $\mu \mathrm{L}$ de Taq DNA polimerase (5 unidades/ $\mu \mathrm{L}$; Promega), $12,5 \mu \mathrm{L}$ de água ultrapura e $1,5 \mu \mathrm{L}$ do produto da pré-amplificação diluído. O programa de amplificação seletiva consistiu de desnaturação inicial a $94^{\circ} \mathrm{C}$ por 2 minutos, 12 ciclos compostos de 30 segundos a $94^{\circ} \mathrm{C}, 30$ segundos a $65^{\circ} \mathrm{C}\left(-7^{\circ} \mathrm{C}\right.$ por ciclo) e 1 minuto a $72^{\circ} \mathrm{C}$ seguidos de 23 ciclos compostos de 30 segundos a $94^{\circ} \mathrm{C}, 30$ segundos a $56^{\circ} \mathrm{C}$ e 1 minuto a $72^{\circ} \mathrm{C}$. O ciclo final de extensão foi seguido de 2 minutos a $72^{\circ}$. A reação foi armazenada a $-20^{\circ} \mathrm{C}$.

As amostras foram submetidas à eletroforese em gel de poliacrilamida [acrilamida /bisacrilamida (19:1) 6\%, uréia 7,5 M e tampão TBE 1X] de 0,5 mm de espessura. Utilizou-se o sistema eletroforético "Sequi-Gen GT" (Biorad) de $38 \times 50 \mathrm{~cm}$ e pente para 50 amostras. No preparo de um litro da solução matriz dos géis foram utilizados 420,4 g de uréia, $3 \mathrm{~g}$ de bisacrilamida, $60 \mathrm{~g}$ de acrilamida e TBE $1 X$ até completar o volume final de $1 \mathrm{~L}$. A solução matriz foi filtrada em filtro de 0,2 $\mu \mathrm{m}$. Em seguida, foi armazenada em frascos âmbares envoltos em papel alumínio e mantida em refrigerador.

As placas utilizadas na montagem do gel foram cuidadosamente limpas utilizando-se etanol 95\%. Na placa maior foram aplicados $2 \mathrm{~mL}$ de REPEL (Amersham), espalhando-se com lenços de papel em movimentos circulares. $O$ 
excesso foi removido com lenço de papel umedecido em etanol $95 \%$ após 5 minutos de secagem do produto. Para o tratamento da placa menor foram misturados, em um tubo "eppendorf" de 1,5 mL, $1 \mathrm{~mL}$ de etanol $95 \%, 5 \mu \mathrm{L}$ de ácido acético glacial e $5 \mu \mathrm{L}$ de BIND (Amersham). Em seguida, o produto foi aplicado sobre a placa e cuidadosamente espalhado com lenços de papel em movimentos circulares. $O$ excesso foi retirado com lenço de papel umedecido em etanol $95 \%$ após 5 minutos de secagem do produto.

Para o preparo do gel foram utilizados $120 \mathrm{~mL}$ da solução matriz, $120 \mu \mathrm{L}$ de TEMED e $800 \mu \mathrm{L}$ de persulfato de amônio 10\%. Ao produto da amplificação seletiva foram adicionados $8 \mu \mathrm{L}$ de tampão formamida (formamida 98\%, EDTA $10 \mathrm{mM} \mathrm{pH} 8,0$, azul bromofenol 0,002\% (p/v) e xileno cianol 0,002\% (p/v)). Em seguida, as amostras foram desnaturadas a $95^{\circ} \mathrm{C}$ por 5 minutos. Antes da aplicação das amostras no gel (15 $\mu \mathrm{L})$, este foi submetido a uma eletroforese inicial (pré-corrida) sob potência constante de $80 \mathrm{~W}(40-50 \mathrm{~V} / \mathrm{cm})$ por uma hora. $\mathrm{Na}$ parte superior da cuba foi utilizado TBE $1 \mathrm{X}$ e, na parte inferior, TBE 1X/acetato de sódio 0,375 M. Após a pré-corrida, os poços foram limpos utilizando uma agulha acoplada a uma seringa e, em seguida, as amostras foram aplicadas no gel. Estas foram submetidas à eletroforese sob potência constante de $80 \mathrm{~W}$ durante aproximadamente 4 horas.

Para a revelação dos géis utilizou-se o método de coloração com nitrato de prata seguindo o protocolo proposto por Creste et al. (2001). Após a eletroforese, as placas foram cuidadosamente separadas e o gel aderido à placa menor foi corado com nitrato de prata. Para tanto, o gel foi imerso em $2 \mathrm{~L}$ de solução para fixação (etanol $10 \%$ e ácido acético 1\%) e mantido sob lenta agitação durante 10 minutos. Em seguida, o gel foi lavado com agitação em $2 \mathrm{~L}$ de água destilada, durante 1 minuto. $O$ procedimento de pré-tratamento foi realizado pela imersão em $2 \mathrm{~L}$ de solução de oxidação (ácido nítrico 1,5\%) durante 3 minutos procedendo-se, em seguida, nova lavagem do gel com água destilada durante 1 minuto. $O$ gel foi corado com $2 \mathrm{~L}$ de solução de nitrato de 
prata $\left(\mathrm{AgNO}_{3}\right)$ 0,2\% durante 20 minutos, sob agitação. Em seguida, foram realizadas duas novas lavagens de 30 segundos com água destilada. A revelação dos géis foi realizada através de imersão em 1 litro de solução contendo $\mathrm{Na}_{2} \mathrm{CO}_{3} 3 \%$ e formaldeído $0,02 \%$, sob lenta agitação. Quando começaram a surgir as primeiras bandas no gel, o mesmo foi transferido para nova solução de revelação de igual volume agitando-se levemente até atingir o padrão de revelação desejado. Após a revelação, o gel foi imerso em $2 \mathrm{~L}$ de solução bloqueadora (ácido acético glacial 5\%) durante 5 minutos sob lenta agitação. Após uma lavagem final com água destilada durante 1 minuto, a placa foi colocada em posição vertical em um local seco e arejado, sob temperatura ambiente para secagem do gel, possibilitando posterior análise dos fragmentos.

\subsubsection{Testes de segregação mendeliana}

O teste de qui-quadrado $\left(\chi^{2}\right)$ foi utilizado para verificar se os marcadores microssatélites e AFLP que revelaram polimorfismos apresentavam padrão de segregação Mendeliana. Para controlar o nível de significância conjunto, foi utilizado o critério de Bonferroni. Quando são realizados $n$ testes independentes, a probabilidade de se cometer erro tipo I em pelo menos um dos testes é $1-\left(1-\alpha_{T}\right)^{n}$. Denominando esta grandeza de $\alpha_{T}$ (nível de significância global), tem-se que o valor $\alpha$ em cada teste, para $\alpha_{T}$ fixo, pode ser aproximadamente obtido por $\alpha_{T} / n$. Portanto, considerando um $\alpha_{T}=5 \%$ com $n=$ 62 marcadores (17 SSR e 45 AFLP), realizou-se o teste de $\chi^{2}$ com $\alpha=0,08 \%$.

No caso dos marcadores microssatélites, testou-se a hipótese de que os marcadores apresentavam uma segregação de 1:1, que é a proporção esperada na geração $F_{1} R C_{1}$ de plantas com os dois alelos marcadores e apenas com o alelo marcador do genitor suscetível. Utilizou-se a seguinte expressão para o teste de $\chi^{2}$ : 


$$
\chi^{2}=\left[\left(\mathrm{no}_{12}-\mathrm{ne}_{12}\right)^{2} / \mathrm{ne}_{12}\right]+\left[\left(\mathrm{no}_{22}-\mathrm{ne}_{22}\right)^{2} / \mathrm{ne}_{22}\right]
$$

em que: no ${ }_{12}$ e ne ${ }_{12}$ são os números observados e esperados de plantas heterozigóticas para o marcador e $\mathrm{no}_{22}$ e ne $\mathrm{ne}_{22}$ são os números observados e esperados de plantas homozigóticas para o alelo marcador do genitor suscetível.

Para os marcadores AFLP testou-se a hipótese 1:1 para presença e ausência do alelo marcador. Utilizou-se a seguinte expressão para o teste de $\chi^{2}$ :

$$
\chi^{2}=\left[\left(\mathrm{no}_{1}-\mathrm{ne}_{1}\right)^{2} / \mathrm{ne}_{1}\right]+\left[\left(\mathrm{no}_{0}-\mathrm{ne}_{0}\right)^{2} / \mathrm{ne}_{0}\right]
$$

em que: no ${ }_{1}$ e ne ${ }_{1}$ são os números observados e esperados de plantas com a presença do marcador e no e ne $_{0}$ são os números observados e esperados de plantas com a ausência do marcador (Draper \& Smith, 1998).

\subsubsection{Análise de marcas simples e construção do mapa de ligação}

Apenas marcadores que apresentaram segregação Mendeliana foram utilizados nas análises de ligação. Associações entre marcadores e QRLs foram determinadas pela análise de regressão linear simples utilizando as médias ajustadas dos dois experimentos e da análise conjunta. O efeito do marcador foi dado pelo coeficiente de regressão. Um nível $\alpha$ de 0,05 foi utilizado (Dudley, 1993) para declarar como significativa a associação entre marcador e QRL pela análise de marcas simples. Nas análises de regressão para marcadores SSR utilizou-se o código 0 para representar indivíduos homozigóticos para o alelo marcador do genitor suscetível e 1 para indivíduos heterozigóticos. Os marcadores AFLP também foram codificados como 0 e 1, representando ausência e presença do fragmento amplificado. 
Foi construído um mapa genético utilizando o programa MAPMAKER (Lander et al., 1987) versão 3.0. Os grupos de ligação foram estabelecidos utilizando um lod score mínimo de 3,0 e máxima distância de $50 \mathrm{cM}$. As freqüências de recombinação foram convertidas em distância de mapa utilizando a função de mapeamento de Kosambi (1944). Após o agrupamento dos locos marcadores em grupos de ligação, a ordem dos mesmos foi determinada. No caso de grupos com número de marcadores menor ou igual a oito, a ordem mais provável foi obtida usando o comando compare e, para os demais grupos, foi usado o comando order, adotando-se como critério de ordenação um LOD > 3,0. Para confirmação da ordem obtida, utilizou-se o comando ripple. Após ordenação dos marcadores nos grupos de ligação, foi feita a tentativa de adicionar marcadores que não entraram nos grupos através do comando try. Após a adição dos mesmos, a nova ordem foi submetida à confirmação usando o comando ripple.

\subsubsection{Análise de regressão linear múltipla}

Apenas marcadores significativamente associados a QRLs para antracnose foliar em cada experimento, identificados pela análise de regressão linear simples a $\mathrm{P}<0,05$ (Tabela 17), foram incluídos na análise de regressão múltipla. Para a seleção das variáveis regressoras foi utilizado o método de eliminação por stepwise ( $P<0,05$ para entrada e $P<0,05$ para saída do modelo), onde os marcadores são considerados como variáveis independentes e a característica fenotípica como variável dependente. Os locos marcadores de maior significância foram identificados através de valores do teste $F$ parcial $(\mathrm{P}<0,05)$ e a porcentagem da variação fenotípica explicada por eles foi dada pelo coeficiente de determinação $\left(R^{2}\right)$. 


\subsubsection{Mapeamento de QRLs por intervalo composto}

Após a construção do mapa de ligação, realizou-se o mapeamento por intervalo composto (Zeng, 1994), utilizando o programa QTL Cartographer para Windows versão 1.21 (Basten et al., 2000), com 2 cM de intervalo de precisão. O modelo de regressão backward e forward utilizando uma "janela" de $10 \mathrm{cM}$ foi aplicado para controlar a interferência de QRLs múltiplos. Para declarar a presença de um QTL foi usado como critério um LOD > 3 .

O modelo estatístico para o mapeamento por intervalo composto em um segmento entre os marcadores i e i+1 é o seguinte:

$$
Y_{j}=b_{0}+b_{i} X_{i j}+\sum_{k \neq i, i \neq 1} b_{k} X_{k j}+e_{j}
$$

em que:

$Y_{j}$ : valor da característica analisada para a família j;

$\mathrm{b}_{0}$ : intercepto do modelo;

$b_{\mathrm{i}}$ : efeito genético de um QTL localizado entre os dois marcadores i e i+1;

$X_{\mathrm{ij}}$ : variável dummy que pode assumir valores 0 e 1, conforme a combinação dos genótipos dos marcadores i e i+1; cada classe dos genótipos marcadores tem uma determinada probabilidade de ocorrência, que é função da distância entre marcador i com o QTL e entre os marcadores i e i+1;

$b_{k}$ : coeficiente de regressão parcial do valor da característica do marcador $k$;

$\mathrm{X}_{\mathrm{kj}}$ : variável dummy para o marcador k na família j;

$e_{i j}$ : erro do modelo. 


\section{RESULTADOS E DISCUSSÃO}

\subsection{Modelo de herança mista para resistência a C. graminicola}

\subsubsection{Avaliação da reação a C. graminicola em quatro cruzamentos}

As análises de variância individuais dos experimentos e a análise conjunta para severidade de antracnose foliar estão apresentadas nas Tabelas 6 e 7. A precisão experimental estimada por CVa (\%) e CVb (\%) das análises individuais e da análise conjunta foi superior à relatada anteriormente para avaliação de antracnose foliar (Zuber et al., 1981) e de outras doenças de milho (Paterniani et al., 2000). Corroborando com a precisão experimental, não foram observadas diferenças significativas entre blocos e entre blocos dentro de época, o que sugere que o inóculo foi uniformemente distribuído nos experimentos e que não houve efeito do ambiente em blocos. Os cruzamentos diferiram estatisticamente quanto à severidade de doença $(P<0,05)$ nas análises individuais, indicando que as constituições genéticas das linhagens, em relação aos genes de resistência, são diferentes. Gerações dentro de cruzamentos também diferiram $(P<0,01)$, mostrando que há segregação de genes de resistência a $C$. graminicola. A análise conjunta dos experimentos revelou que os efeitos de experimento, experimento x cruzamento, geração dentro de cruzamento e experimento $x$ geração dentro de cruzamento foram significativos $(P<0,01)$. Entretanto, os cruzamentos não diferiram significativamente na análise conjunta. 
Tabela 6. Resumo das análises de variância da severidade de antracnose foliar de milho avaliada em gerações de quatro cruzamentos em dois experimentos. Jardinópolis, SP

\begin{tabular}{lccccc}
\hline \multirow{2}{*}{ FV } & \multirow{2}{*}{ GL } & \multicolumn{2}{c}{ Experimento 1 } & \multicolumn{2}{c}{ Experimento 2 } \\
\cline { 3 - 6 } & 2 & QM & Prob. > F & QM & Prob. $>$ F \\
\hline Bloco & 2,0952 & 0,2072 & 0,2058 & 0,1377 \\
Cruzamento (C) & 3 & 0,3157 & 0,0282 & 0,5520 & 0,0231 \\
Erro a & 6 & 0,0460 & & 0,0732 & \\
Geração/C & 20 & 2,1578 & $<0,0001$ & 6,9150 & $<0,0001$ \\
Erro b & 40 & 0,0267 & & 0,0660 & \\
& & & & \multicolumn{2}{c}{12,6} \\
CV erro a (\%) & \multicolumn{2}{c}{14,3} & \multicolumn{2}{c}{12,0} \\
CV erro b (\%) & & 10,9 & & \\
\hline
\end{tabular}

Tabela 7. Resumo da análise de variância conjunta de dois experimentos da severidade de antracnose foliar de milho avaliada em gerações de quatro cruzamentos. Jardinópolis, SP

\begin{tabular}{lccc}
\hline \multicolumn{1}{c}{ Fonte de Variação } & $\mathrm{GL}$ & $\mathrm{QM}$ & Prob. $>\mathrm{F}$ \\
\hline Bloco/Experimento & 4 & 0,1505 & 0,0959 \\
Experimento & 1 & 15,3146 & $<0,0001$ \\
Cruzamento & 3 & 0,0840 & 0,2882 \\
E x C & 3 & 0,7837 & 0,0004 \\
Erro a & 12 & 0,0596 & \\
Geração/cruzamento & 20 & 8,1224 & $<0,0001$ \\
Éxperimento x geração/ cruzamento & 20 & 0,9505 & $<0,0001$ \\
Erro b & 80 & 0,0467 & \\
& & & \\
CV erro a (\%) & & 13,4 & \\
CV erro b (\%) & & 11,8 & \\
\end{tabular}

Em geral, as médias de severidade de doença (Tabela 8) do experimento instalado em dezembro foram superiores às de novembro de 2001, indicando 
que o plantio tardio foi mais favorável ao desenvolvimento do patógeno. Esta observação está de acordo com Bergstrom \& Nicholson (1999), que comentam sobre a dificuldade de controle da doença em plantios tardios em locais nos quais o patógeno é endêmico. Houve uma inversão nos comportamentos das linhagens suscetíveis entre experimentos. As médias de severidade da linhagem DAS6 foram superiores em novembro, enquanto que as de DAS22 foram superiores em dezembro de 2001, sugerindo a presença de interação genótipo $x$ ambiente. Já as linhagens resistentes (DAS4 e DAS3) não apresentaram sintomas da doença. Os comportamentos das linhagens DAS6 e DAS4 foram semelhantes aos obtidos por Coêlho et al. (2001), que relataram pela primeira vez uma linhagem resistente (DAS4) sem sintomas de infecção. A ausência de sintomas nesta linhagem sugere a presença de um gene de resistência de efeito maior.

Tabela 8. Médias de severidade de antracnose foliar de gerações avaliadas em quatro cruzamentos de milho em dois experimentos. Jardinópolis, SP

\begin{tabular}{lcccc}
\hline Geração & DAS6 x DAS4 & DAS6 x DAS3 & DAS22 x DAS4 & DAS22 x DAS3 \\
\hline $\mathrm{P}_{1}$ & 3,78 & \multicolumn{4}{c}{ Novembro de 2001 } \\
$\mathrm{P}_{2}$ & 1,00 & 3,38 & 2,75 & 2,58 \\
$\mathrm{~F}_{1}$ & 1,00 & 1,00 & 1,00 & 1,00 \\
$\mathrm{~F}_{2}$ & 1,28 & 1,08 & 1,00 & 1,03 \\
$\mathrm{RC}_{1}$ & 1,81 & 1,32 & 1,19 & 1,23 \\
$\mathrm{RC}_{2}$ & 1,00 & 1,65 & 1,54 & 1,33 \\
& & 1,05 & 1,03 & 1,00 \\
$\mathrm{P}_{1}$ & 4,40 & Dezembro de 2001 & \\
$\mathrm{P}_{2}$ & 1,00 & 4,75 & 5,28 & 5,14 \\
$\mathrm{~F}_{1}$ & 1,07 & 1,00 & 1,00 & 1,00 \\
$\mathrm{~F}_{2}$ & 1,51 & 1,18 & 1,00 & 1,00 \\
$\mathrm{RC}_{1}$ & 2,39 & 2,00 & 2,00 & 1,84 \\
$\mathrm{RC}_{2}$ & 1,00 & 2,74 & 3,13 & 3,08 \\
\hline
\end{tabular}


As médias de $F_{1}$ e $R C_{2}$ de todos os experimentos foram similares às dos genitores resistentes. Já as médias de $\mathrm{RC}_{1}$ e $\mathrm{F}_{2}$ foram intermediárias às médias dos genitores, sendo que a média de $F_{2}$ tendeu para a média do resistente.

Tanto as médias das gerações quanto as distribuições de freqüência das notas de severidade de doença indicam ação gênica de dominância (Figuras 1 a 4). A distribuição não normal das notas de severidade de doença, com maior número de indivíduos nas classes consideradas resistentes, são um indicativo de herança oligogênica. No entanto, apesar de terem sido realizadas duas inoculações artificiais em cada experimento, é possível que alguns indivíduos classificados como resistentes na verdade representem escapes, isto é, não receberam inóculo ou este não foi eficiente em causar infecção. 

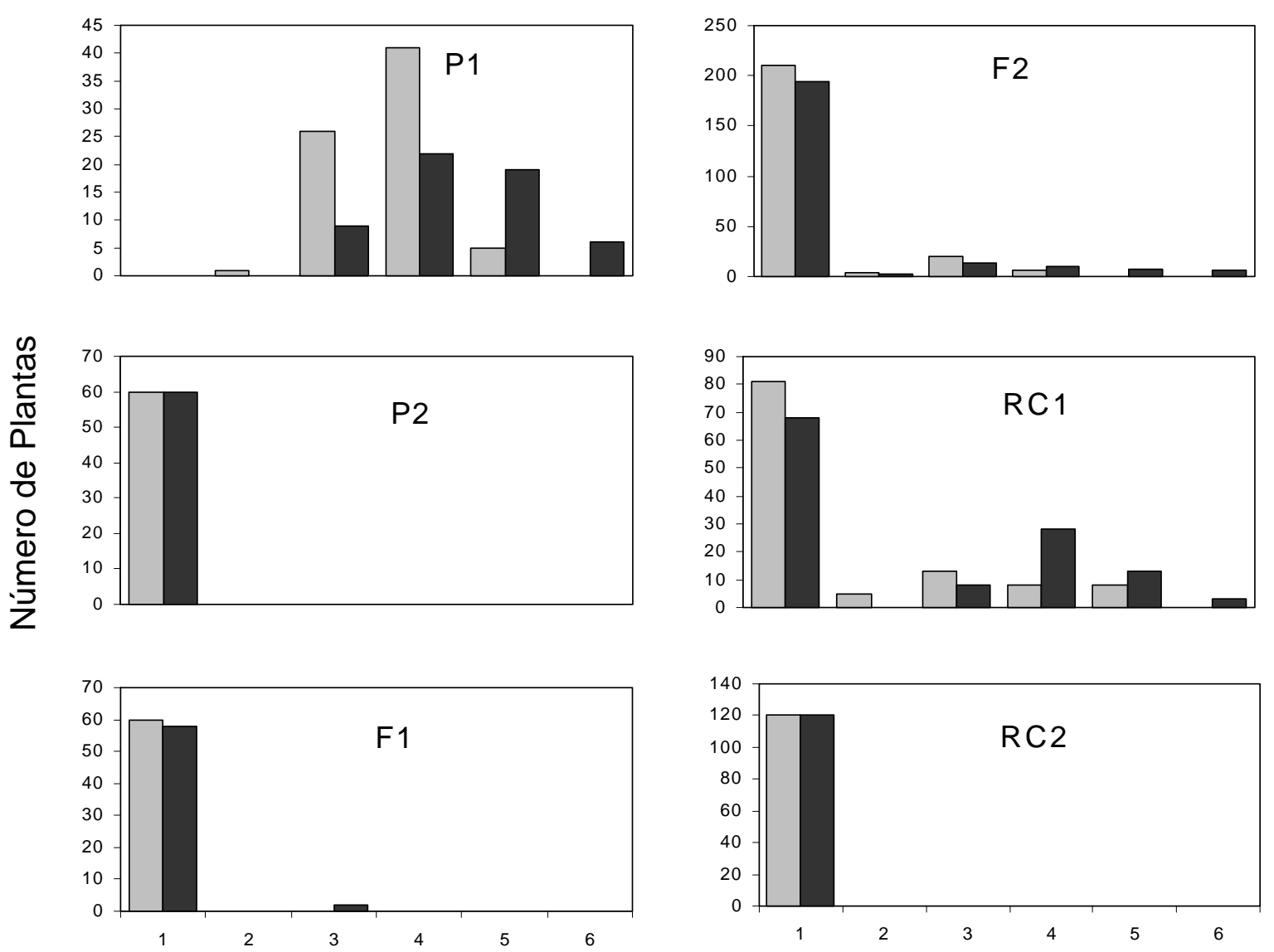

Notas de severidade de antracnose foliar em milho

Figura 1 - Distribuições de freqüência de notas de severidade de antracnose foliar nas linhagens genitoras e gerações $F_{1}, F_{2}, R C_{1}$ e $R C_{2}$ derivadas do cruzamento DAS6 x DAS4. Barras de cor cinza e preto representam dados dos experimentos de novembro e dezembro de 2001, respectivamente 

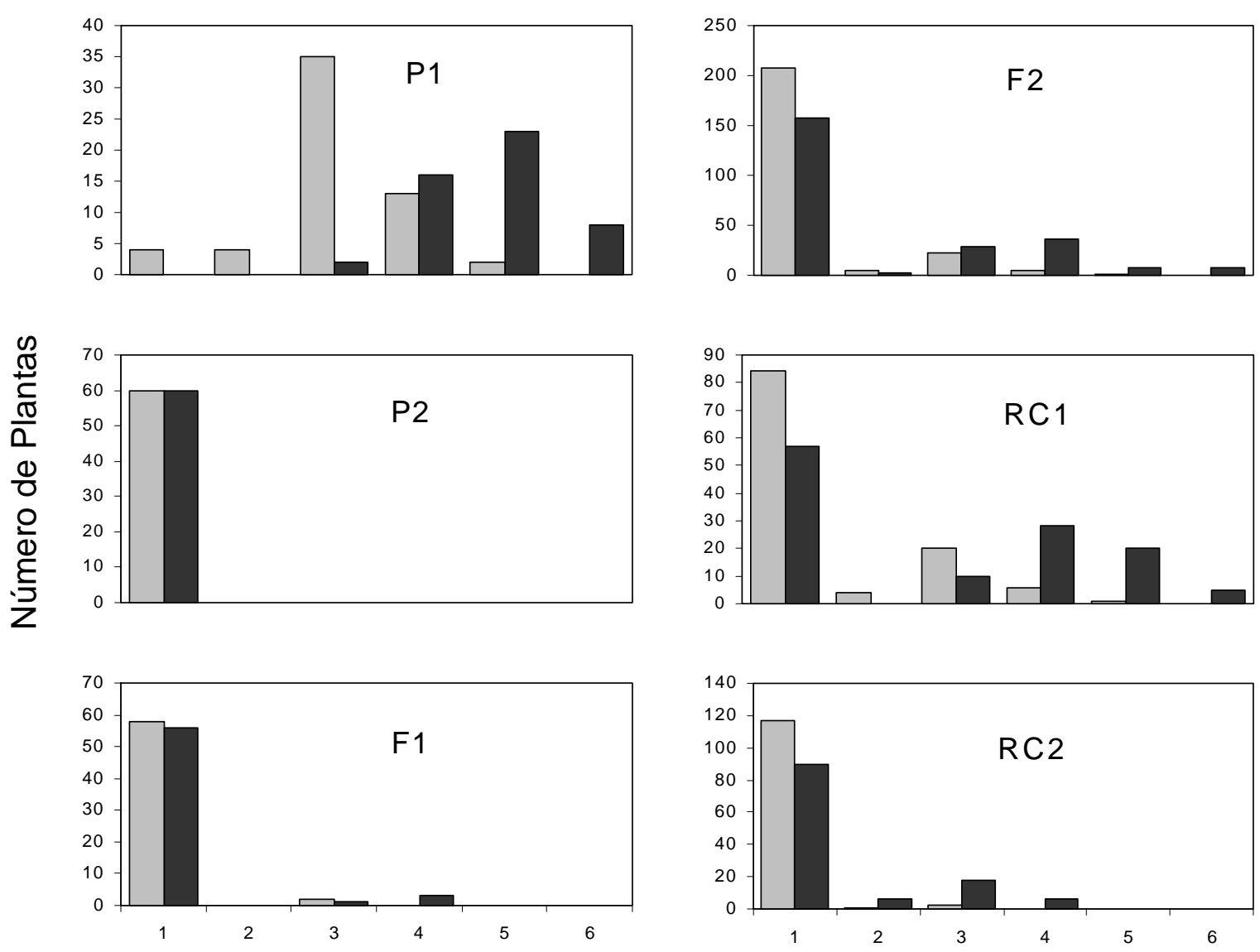

Notas de severidade de antracnose foliar em milho

Figura 2 - Distribuições de freqüência de notas de severidade de antracnose foliar nas linhagens genitoras e gerações $F_{1}, F_{2}, R C_{1}$ e $R C_{2}$ derivadas do cruzamento DAS6 6 DAS3. Barras de cor cinza e preto representam dados dos experimentos de novembro e dezembro de 2001, respectivamente 

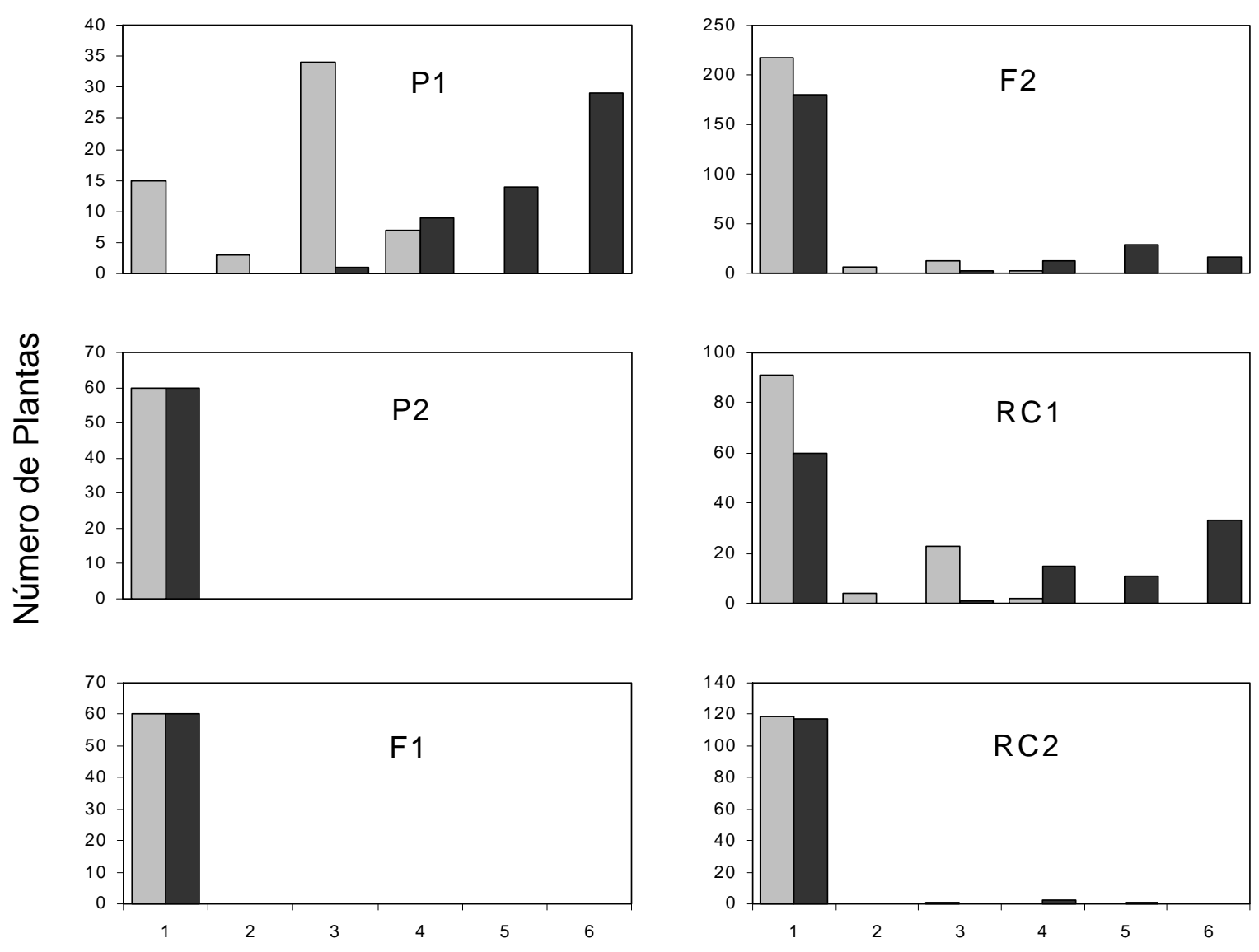

Notas de severidade de antracnose foliar em milho

Figura 3 - Distribuições de freqüência de notas de severidade de antracnose foliar nas linhagens genitoras e gerações $F_{1}, F_{2}, R C_{1}$ e $R C_{2}$ derivadas do cruzamento DAS22 x DAS4. Barras de cor cinza e preto representam dados dos experimentos de novembro e dezembro de 2001, respectivamente 

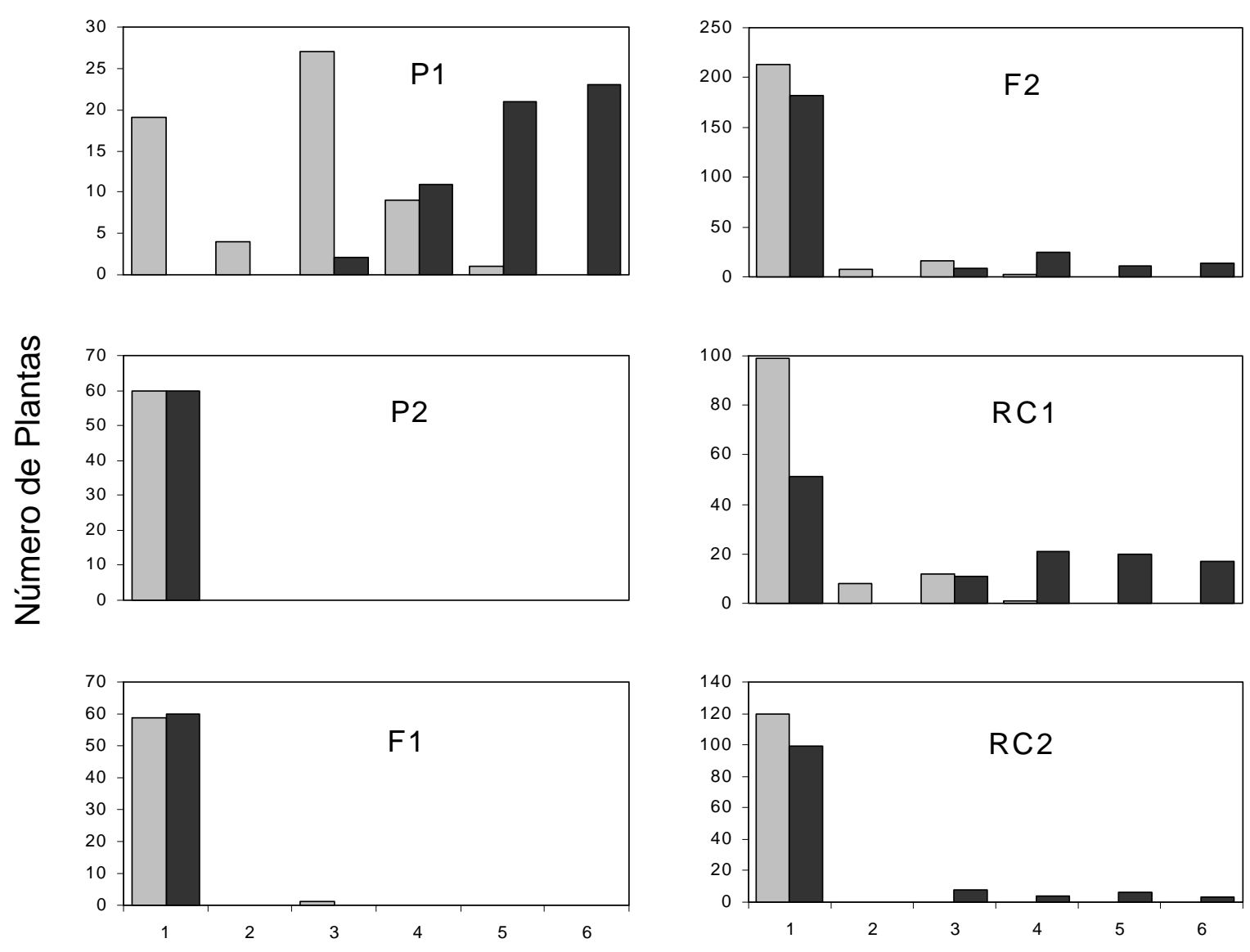

Notas de severidade de antracnose foliar em milho

Figura 4 - Distribuições de freqüência de notas de severidade de antracnose foliar nas linhagens genitoras e gerações $F_{1}, F_{2}, R_{1}$ e $R_{2}$ derivadas do cruzamento DAS22 x DAS3. Barras de cor cinza e preto representam dados dos experimentos de novembro e dezembro de 2001, respectivamente

\subsubsection{Testes de hipóteses sobre os modelos de herança genética}

Os resultados dos testes de hipóteses sobre os modelos genéticos variaram conforme o cruzamento e o experimento (Tabela 9). No cruzamento 
DAS6 x DAS4, obteve-se um valor de $\chi^{2}$ negativo no experimento de novembro de 2001 para a razão de verossimilhança entre os modelos 1 e 5 , que testa a evidência de segregação de um gene de efeito maior. Este valor negativo pode ser devido a falhas na convergência das funções de verossimilhança. Este é um problema intrínseco ao método de análise que ocorre quando não são encontrados valores para os parâmetros que atinjam o ponto de máxima verossimilhança. Embora não tenha sido possível testar a hipótese de um gene de efeito maior no cruzamento DAS6 x DAS4 devido a este problema, há outra evidência da presença deste gene dada pela significância do contraste entre os modelos 7 e 8, que testa ação gênica de dominância para o gene de efeito maior. Os testes entre os modelos 1 e 7 e entre os modelos 5 e 6 também foram significativos, evidenciando a presença de poligenes com ação gênica de dominância. Já em dezembro de 2001, todas as hipóteses testadas foram significativas, podendo-se inferir sobre a presença de um gene de efeito maior com ação gênica de dominância e poligenes também com dominância. Portanto, o modelo selecionado para este cruzamento foi o modelo de herança mista (modelo 1).

No cruzamento DAS6 $\times$ DAS3, apenas os testes para a razão de verossimilhança entre os modelos 1 e 5 e entre os modelos 7 e 8 foram significativos em novembro de 2001, evidenciando a presença de um gene de efeito maior com dominância. Entretanto, em dezembro de 2001, testes entre os modelos 1 e 7 e entre os modelos 5 e 6 , que evidenciam a segregação de poligenes com dominância, também foram significativos. Assim, os modelos que melhor se ajustaram aos dados foram os modelos 7 e 1, para novembro e dezembro, respectivamente. 
Tabela 9. Valores de qui-quadrado $\left(\chi^{2}\right)$ para os testes de hipóteses sobre os modelos de herança genética dos quatro cruzamentos avaliados em dois experimentos

\begin{tabular}{|c|c|c|c|c|c|c|}
\hline \multirow{2}{*}{ Contraste } & \multirow{2}{*}{ Hipótese testada } & \multirow{2}{*}{$\mathrm{GL}$} & \multicolumn{4}{|c|}{ Cruzamentos } \\
\hline & & & DAS6 $\times$ DAS4 & DAS6 $\times$ DAS3 & DAS22 x DAS4 & DAS22 $\times$ DAS3 \\
\hline & & & \multicolumn{4}{|c|}{ Novembro de 2001} \\
\hline Mod.1 x Mod.5 & Gene de efeito maior & 2 & $\mathrm{vn}$ & $397,1^{* *}$ & $231,1^{* *}$ & $1002,3^{\star *}$ \\
\hline Mod.7 x Mod. 8 & Dominância para o gene maior & 1 & $1064,7^{\star \star}$ & $727,4^{\star *}$ & $535,0^{\star *}$ & $373,7^{* *}$ \\
\hline Mod. 1 x Mod.7 & Poligenes & 5 & $1458,2^{* *}$ & 2,5 & $55,0^{* *}$ & $1102,3^{* *}$ \\
\hline \multirow[t]{2}{*}{ Mod. 5 x Mod. 6} & Dominância para poligenes & 3 & $2924,3^{\star *}$ & - & $322,6^{\star *}$ & $445,0^{\star *}$ \\
\hline & & & \multicolumn{4}{|c|}{ Dezembro de 2001} \\
\hline Mod. 1 x Mod.5 & Gene de efeito maior & 2 & $415,3^{* *}$ & $200,7^{* *}$ & $556,6^{* *}$ & $225,6^{* *}$ \\
\hline Mod.7 x Mod. 8 & Dominância para o gene maior & 1 & $890,6^{* *}$ & $385,1^{* *}$ & $1063,9^{* *}$ & $437,5^{\star *}$ \\
\hline Mod. 1 x Mod.7 & Poligenes & 5 & $292,7^{* *}$ & $35,6^{\star *}$ & 9,3 & $111,8^{* *}$ \\
\hline Mod.5 x Mod.6 & Dominância para poligenes & 3 & $746,6^{\star *}$ & $224,0^{* *}$ & - & $319,1^{* *}$ \\
\hline
\end{tabular}


Todas as hipóteses testadas foram significativas em novembro de 2001 para o cruzamento DAS22 x DAS4. Todavia, apenas os testes entre os modelos 1 e 5 e entre os modelos 7 e 8 foram significativos no segundo experimento, indicando segregação monogênica com efeito de dominância. Neste cruzamento, os dados de novembro se ajustaram melhor ao modelo 1 e os dados de dezembro, ao modelo 7.

No cruzamento DAS22 x DAS3, todas as hipóteses genéticas testadas foram significativas tanto em novembro quanto em dezembro de 2001. Portanto, o modelo 1 contendo um gene de efeito maior com ação gênica de dominância e poligenes com dominância foi selecionado para este cruzamento.

O modelo 1, que assume herança mista de um gene de efeito maior $\mathrm{e}$ poligenes, foi selecionado para todos os cruzamentos em pelo menos um dos experimentos. Já o modelo 7 , que assume herança exclusivamente monogênica, foi selecionado em apenas um dos experimentos para os cruzamentos DAS6 x DAS3 e DAS22 x DAS4. A não detecção de efeitos poligênicos em certos experimentos pode ser atribuída a efeitos ambientais na expressão dos mesmos e a erros na avaliação de severidade, uma vez que os dados das seis gerações usados nas análises consistiram de medições de plantas individuais. Para contornar este problema, dados baseados em medições de famílias derivadas de $F_{2}, R_{1}$ e $R C_{2}$, poderiam ser usados para reduzir o erro experimental (Wang \& Gai, 2001). Todavia, análises de modelos mistos baseados em avaliações de famílias derivadas de $F_{2}$ e de retrocruzamentos ainda não foram desenvolvidas. Outra limitação da análise utilizada no presente trabalho é o fato dela não considerar o delineamento experimental e, portanto, não remover componentes da variação experimental.

Todos os modelos selecionados nas análises dos quatro cruzamentos evidenciaram a presença de um gene de efeito maior com efeito aditivo e de dominância. Estes resultados concordam com os obtidos por Coêlho et al. (2001), por Badu-Apraku et al. (1987) e também com os resultados da avaliação 
fenotípica apresentados no item 4.1.1. A consistência das observações permite inferir sobre o poder do método de análise utilizado no presente trabalho para estudar a herança da resistência à antracnose foliar em milho.

\subsubsection{Parâmetros genéticos para resistência a $C$. graminicola}

As estimativas dos parâmetros genéticos dos modelos selecionados para cada cruzamento estão apresentadas na Tabela 10. Os efeitos genéticos tanto aditivos como dominantes do gene de efeito maior foram negativos em todas os cruzamentos, indicando que estes efeitos contribuem para reduzir a severidade da doença (Figuras 1 a 4). Já os efeitos aditivos e de dominância dos poligenes foram positivos ou negativos, dependendo do cruzamento e do experimento. Estes resultados permitem inferir que há diferenças nas constituições genéticas dos cruzamentos em relação aos poligenes de resistência. Algumas estimativas de variância aditiva e de dominância dos poligenes $\left(V_{A}\right.$ e $\left.V_{D}\right)$ foram iguais a zero, apesar de o modelo selecionado indicar presença de variação poligênica. Como não há coerência nestes resultados, presume-se que estas variâncias sejam de pequena magnitude ou há um grande erro associado às suas estimativas. De fato, observa-se que estas estimativas apresentaram um intervalo de confiança, com 95\% de probabilidade (dados não apresentados), ao redor de zero. Badu-Apraku et al. (1987) obtiveram uma estimativa negativa de variância aditiva que, para finalidades práticas, foi considerada igual a zero. Os autores sugeriram algumas explicações para a obtenção desta estimativa que podem ser extrapoladas para o presente trabalho. Uma das pressuposições, tanto da análise de modelos mistos quanto da análise de médias de gerações, é que a variação ambiental seja a mesma dentro de cada geração. Diferentes graus de competição entre as plantas dentro da parcela, devido a diferenças no vigor, podem ter proporcionado condições nas quais os ambientes foram diferentes para as gerações em cada repetição. Outra 
limitação destas metodologias de análise é o fato de se considerarem segregação independente de genes. Quando as pressuposições da análise não são totalmente satisfeitas, é possível a obtenção de estimativas viesadas.

Tabela 10. Estimativas dos parâmetros genéticos relativos aos modelos selecionados para os quatro cruzamentos em dois experimentos

\begin{tabular}{lcccccccccc}
\hline Cruzamento & Mod. & $\mu$ & $\mathrm{A}$ & $\mathrm{D}$ & {$[\mathrm{a}]$} & {$[\mathrm{d}]$} & $\mathrm{V}_{\mathrm{A}}$ & $\mathrm{V}_{\mathrm{D}}$ & $\mathrm{S}_{\mathrm{AD}}$ & $\sigma^{2}$ \\
\hline & \multicolumn{1}{c}{ Novembro de 2001} \\
DAS6 x DAS4 & 1 & 2,34 & $-1,27$ & $-1,27$ & $-0,07$ & $-0,06$ & 0,00 & 0,00 & $-0,10$ & 0,10 \\
DAS6 x DAS3 & 7 & 2,20 & $-1,19$ & $-1,17$ & - & - & - & - & - & 0,14 \\
DAS22 x DAS4 & 1 & 1,91 & $-1,03$ & $-1,03$ & 0,10 & 0,19 & 0,00 & 0,00 & $-0,11$ & 0,15 \\
DAS22 x DAS3 & 1 & 1,81 & $-0,99$ & $-0,99$ & 0,11 & 0,24 & 0,00 & 0,00 & $-0,13$ & 0,13 \\
& \multicolumn{1}{c}{ Dezembro de 2001} \\
DAS6 x DAS4 & 1 & 2,67 & $-1,60$ & $-1,61$ & $-0,06$ & $-0,05$ & 0,00 & 0,00 & $-0,17$ & 0,18 \\
DAS6 x DAS3 & 1 & 2,83 & $-1,47$ & $-1,67$ & $-0,24$ & $-0,30$ & 0,00 & 0,20 & 0,20 & 0,36 \\
DAS22 x DAS4 & 7 & 3,13 & $-2,09$ & $-2,10$ & - & - & - & - & - & 0,24 \\
DAS22 x DAS3 & 1 & 3,09 & $-1,80$ & $-1,78$ & $-0,20$ & $-0,27$ & 0,00 & 0,53 & 0,29 & 0,23
\end{tabular}

$\mu$ : média do cruzamento; A: efeito aditivo do gene de efeito maior; D: efeito de dominância do gene de efeito maior; [a]: efeito aditivo dos poligenes; [d]: efeito de dominância dos poligenes; $\mathrm{V}_{\mathrm{A}}$ : variância aditiva dos poligenes; $\mathrm{V}_{\mathrm{D}}$ : variância de dominância dos poligenes; $\mathrm{S}_{\mathrm{AD}}$ : soma dos produtos dos efeitos aditivos pelos efeitos de dominância dos poligenes; $\sigma^{2}$ : variância ambiental

As estimativas do grau de dominância, herdabilidades e porcentagens da variação explicada pelos efeitos aditivos e de dominância encontram-se na Tabela 11. O grau de dominância (D/A) variou de 0,98 a 1,14. Dominância para resistência a $C$. graminicola também foi encontrada em outros trabalhos (Carson \& Hooker, 1981a; Carson \& Hooker, 1981b; Lim \& White, 1978; Toman \& White, 1993; Badu-Apraku et al., 1987). A possibilidade de se inferir a respeito da interação alélica constitui uma vantagem da utilização de modelos mistos que separam os efeitos genéticos correspondentes ao gene de efeito 
maior e poligenes, uma vez que a relação D/A não serve para esta finalidade quando dois ou mais genes são considerados (Mather \& Jinks, 1971). No presente trabalho, o grau de dominância foi estimado apenas para o gene de efeito maior. Em modelos poligênicos, alguns efeitos de dominância podem ser negativos e outros positivos, levando a valores pequenos de $D$, mesmo que individualmente esses valores não sejam pequenos. Da mesma forma, o valor de A pode ser pequeno porque os genes estão distribuídos entre os genitores de modo que a soma algébrica da contribuição dos locos em homozigose seja pequena.

Tabela 11. Estimativas do grau de dominância, herdabilidades e contribuições dos efeitos genéticos relativas aos modelos selecionados para os quatro cruzamentos em dois experimentos

\begin{tabular}{|c|c|c|c|c|c|c|}
\hline Cruzamento & Modelo & $\mathrm{D} / \mathrm{A}$ & $\hat{\mathrm{h}}_{\mathrm{a}}^{2}$ & $\hat{h}_{r}^{2}$ & $a(\%)$ & $d(\%)$ \\
\hline \multicolumn{7}{|c|}{ Novembro de 2001} \\
\hline DAS6 $\times$ DAS4 & 1 & 1,00 & 0,92 & 0,62 & 66,67 & 33,33 \\
\hline DAS6 6 DAS3 & 7 & 0,98 & 0,88 & 0,59 & 67,42 & 32,58 \\
\hline DAS22 $\times$ DAS4 & 1 & 1,00 & 0,84 & 0,56 & 66,67 & 33,33 \\
\hline DAS22 $\times$ DAS3 & 1 & 1,00 & 0,84 & 0,57 & 66,67 & 33,33 \\
\hline \multicolumn{7}{|c|}{ Dezembro de 2001} \\
\hline DAS6 6 DAS4 & 1 & 1,01 & 0,91 & 0,61 & 66,39 & 33,61 \\
\hline DAS6 $x$ DAS3 & 1 & 1,14 & 0,85 & 0,46 & 54,63 & 45,37 \\
\hline DAS22 $\times$ DAS4 & 7 & 1,00 & 0,93 & 0,62 & 66,45 & 33,55 \\
\hline DAS22 $\times$ DAS3 & 1 & 1,00 & 0,93 & 0,51 & 55,06 & 44,94 \\
\hline
\end{tabular}

D/A: grau de dominância; $h_{a}^{2}$ : herdabilidade no sentido amplo; $h_{r}^{2}:$ herdabilidade no sentido restrito; a (\%): porcentagem da variação explicada pelos efeitos genéticos aditivos; d (\%): porcentagem da variação explicada pelos efeitos genéticos de dominância

As herdabilidades no sentido amplo foram de 0,84 a 0,93 e, no sentido restrito, de 0,46 a 0,62 . Os efeitos genéticos aditivos contribuíram com $54,6 \%$ a $67,4 \%$ da variação total, enquanto os efeitos genéticos de dominância contribuiram com $32,6 \%$ a $45,4 \%$. As estimativas de herdabilidade dos quatro cruzamentos sugerem a possibilidade de obtenção de ganho em resistência 
usando métodos de melhoramento simples, como seleção massal. Entretanto, a seleção utilizando teste de progênie deve ser uma forma mais efetiva de selecionar plantas resistentes à antracnose foliar, uma vez que os componentes de dominância tiveram uma importante contribuição na variação genética total. Devido às interações genótipo $x$ ambiente, as linhagens ou combinações híbridas finais devem ser testadas em vários ambientes para assegurar uma correta avaliação fenotípica.

Conhecer a herança de um caráter discriminando genes de efeito maior e menor é importante para predizer a segregação de um cruzamento em programas de melhoramento (Jiang et al., 1994). A abordagem de modelos mistos é diferente do teste de escala conjunto, normalmente utilizado em genética quantitativa (Mather \& Jinks, 1971). Modelos mistos consideram o sistema genético de um caráter quantitativo como um modelo de herança contendo genes de efeito maior e menor. Já o teste de escala conjunto considera um caráter quantitativo como um sistema poligênico. Entretanto, a análise de modelos mistos pode apenas verificar a presença destes genes, enquanto modelos de mapeamento de QTLs permitem a identificação, localização e quantificação dos seus efeitos na expressão do caráter.

Como mostrado no presente trabalho, a análise de modelos mistos foi capaz de verificar a presença de genes de resistência de milho a $C$. graminicola com maiores e menores efeitos genéticos. A ação gênica tanto do gene de efeito maior quanto dos poligenes foi aditiva e dominante, sendo a ação gênica aditiva de maior importância. 


\subsection{Mapeamento de genes de resistência a C. graminicola}

\subsubsection{Avaliação da reação a C. graminicola em famílias $F_{1: 2} R_{1}$}

Contrastes entre médias de severidade de antracnose foliar das linhagens genitoras diferiram significativamente $(P<0,01)$ nos dois experimentos e na análise conjunta (Tabelas 12 e 13). O híbrido foi significativamente mais resistente que o genitor suscetível (DAS6) $(\mathrm{P}<0,01)$, porém tão resistente quanto o genitor resistente (DAS4), indicando ação gênica de dominância para resistência neste cruzamento. Estes resultados confirmam os obtidos na análise de modelos mistos, relatada no item 4.1, e os resultados de outros trabalhos (Carson \& Hooker, 1981a; Carson \& Hooker, 1981b; Lim \& White, 1978; Toman \& White, 1993; Badu-Apraku et al., 1987). As análises de variância mostraram diferenças significativas entre famílias $(P<0,01)$, o que indica variação genética para a reação a $C$. graminicola. $\mathrm{Na}$ análise de variância conjunta, os efeitos de experimento e tratamento $x$ experimento também foram significativos $(P<0,01)$, indicando a influência ambiental na manifestação da resistência. Vale ressaltar que o segundo experimento foi conduzido tardiamente, quando geralmente as condições são mais propícias ao patógeno (Bergstrom \& Nicholson, 1999). Efeitos significativos da interação genótipo $x$ ambiente em avaliações de resistência de milho à antracnose foliar também foram encontrados na análise de modelos mistos apresentada anteriormente e no trabalho de Carson \& Hooker (1981a). A precisão experimental, avaliada pelo coeficiente de variação experimental $(\mathrm{CVe})$ foi semelhante à obtida em avaliações de outras doenças de milho (Paterniani et al., 2000). As altas estimativas de herdabilidade no sentido amplo e do coeficiente $b$ indicam alta variação genética para resistência à antracnose foliar. Da mesma forma, sugerem que a resistência é controlada por poucos genes, o que permite antever sucesso com a seleção de plantas ou famílias resistentes nas populações segregantes. 
Tabela 12. Resumo das análises de variância de severidade de antracnose foliar avaliada em famílias $F_{1: 2} R C_{1}$, genitores e $F_{1}$ em dois experimentos. Jardinópolis, SP

\begin{tabular}{|c|c|c|c|}
\hline \multirow{2}{*}{ Fonte de Variação } & \multirow{2}{*}{$\mathrm{GL}$} & \multicolumn{2}{|c|}{ Quadrado Médio } \\
\hline & & Experimento 1 & Experimento 2 \\
\hline Tratamentos & 143 & $1,24^{\star *}$ & $3,72^{\star *}$ \\
\hline DAS4 $\times$ DAS6 & 1 & $11,04^{* *}$ & $13,30^{* *}$ \\
\hline DAS4 $\times F_{1}$ & 1 & 0,03 & 0,00 \\
\hline DAS6 $\times F_{1}$ & 1 & $11,73^{* *}$ & $12,90^{* *}$ \\
\hline Famílias & 140 & $1,10^{\star *}$ & $10,68^{* *}$ \\
\hline Erro & 253 & 0,18 & 0,34 \\
\hline Média dos tratamentos & & 1,98 & 2,84 \\
\hline Média de DAS6 & & 3,73 & 4,13 \\
\hline Média de DAS4 & & 0,91 & 0,98 \\
\hline Média de $F_{1}$ & & 0,76 & 1,02 \\
\hline Média das famílias $F_{1: 2} R C_{1}$ & & 1,98 & 2,86 \\
\hline CVe $(\%)$ & & 21,5 & 20,4 \\
\hline$\hat{h}_{\mathrm{a}}^{2}(\%)$ & & 85,88 & 91,68 \\
\hline b & & 1,42 & 1,91 \\
\hline
\end{tabular}

A média ajustada de severidade de antracnose foliar das famílias $F_{1: 2} R C_{1}$ variou de 0,9 a 3,5 no primeiro experimento, e de 1,0 a 5,4 no segundo experimento (Figura 5), mostrando grande variação fenotípica da população, principalmente no experimento de dezembro de 2001. As notas de severidade de doença apresentaram uma distribuição contínua aparentemente bimodal, que geralmente está associada com resistência do tipo monogênica na presença de genes de efeito menor. Esta observação é coerente com os resultados obtidos na análise de modelos mistos descritos anteriormente. 
Tabela 13. Resumo da análise de variância conjunta de dois experimentos de avaliação da severidade de antracnose foliar em famílias $F_{1: 2}$ do retrocruzamento (DAS4 x DAS6) × DAS6, genitores e híbrido $F_{1}$. Jardinópolis-SP

\begin{tabular}{lcc}
\hline \multicolumn{1}{c}{ Fonte de Variação } & $\mathrm{GL}$ & Quadrado Médio \\
\hline Experimento $(\mathrm{E})$ & 1 & $160,66^{* *}$ \\
Tratamento $(\mathrm{T})$ & 143 & $4,21^{* *}$ \\
DAS4 x DAS6 & 1 & $24,30^{* *}$ \\
DAS4 x $\mathrm{F}_{1}$ & 1 & 0,01 \\
DAS6 x $\mathrm{F}_{1}$ & 1 & $24,62^{\star *}$ \\
Família & 140 & $3,95^{\star *}$ \\
E x T & 143 & $0,66^{* *}$ \\
Erro & 506 & 0,26 \\
& & \\
Média dos tratamentos & & 2,41 \\
$\quad$ Média de DAS6 & & 3,93 \\
Média de DAS4 & & 0,94 \\
Média de $\mathrm{F}_{1}$ & & 0,89 \\
Média das famílias $\mathrm{F}_{1: 2} \mathrm{RC}_{1}$ & & 2,42 \\
CVe (\%) & & 21,1 \\
$\hat{\mathrm{h}}_{\mathrm{a}}^{2}(\%)$ & & 88,70 \\
$\mathrm{~b}$ & & 1,62 \\
\hline
\end{tabular}

${ }^{* *}$ Significativo a $1 \%$ de probabilidade pelo teste de $\mathrm{F}$ 


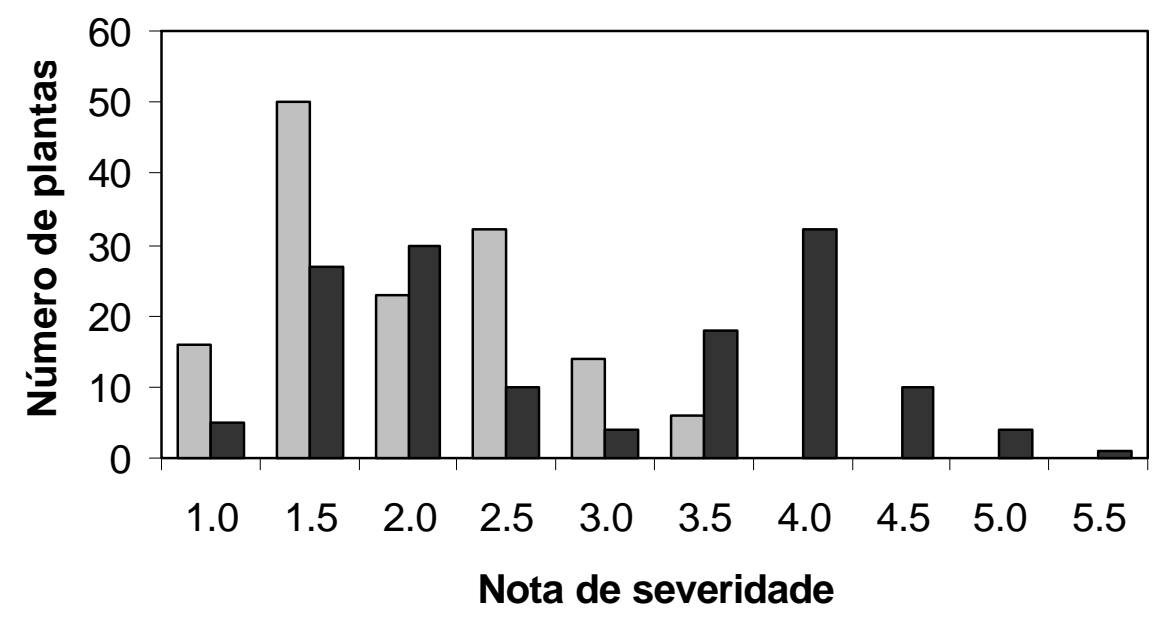

Figura 5 - Distribuição de freqüências de notas médias de severidade de antracnose foliar de famílias $F_{1: 2} R C_{1}$. Barras de cor cinza e preto representam dados dos experimentos de novembro e dezembro de 2001, respectivamente

\subsubsection{Análise de marcadores microssatélites}

Trinta e oito dos 165 pares de primers SSR testados revelaram polimorfismo entre os genitores (Tabela 14). A porcentagem de polimorfismo encontrada, cerca de $23 \%$, pode ser considerada baixa quando comparada a $50 \%$ relatada por Ogliari (1999), 31\% por Brunelli et al. (2002) e $45 \%$ por Lopes (2003). Este fato pode ser explicado pelo parentesco próximo das linhagens utilizadas neste estudo, que foram obtidas de um mesmo sintético. A proximidade genética entre as linhagens genitoras dificulta a localização de genes de interesse em trabalhos de mapeamento, pois os locos marcadores próximos aos genes de interesse podem ser monomórficos. 
Tabela 14. Relação dos primers testados para amplificação de locos microssatélites das linhagens DAS6 e DAS4

\begin{tabular}{|c|c|c|c|c|c|}
\hline Localização (BIN) & Loco SSR & Amplificação & Localização (BIN) & Loco SSR & Amplificação \\
\hline 1.00 & bnlg149 & polimórfico & $2.00 / 2.04$ & $\mathrm{mmc0063}$ & monomórfico \\
\hline 1.01 & phi056 & monomórfico & 2.02 & bnlg125 & monomórfico \\
\hline 1.02 & bnlg109 & polimórfico & 2.03 & bnlg238 & monomórfico \\
\hline 1.02 & bnlg176 & monomórfico & 2.04 & bnlg108 & monomórfico \\
\hline 1.02 & bnlg1007 & polimórfico & 2.04 & phi083 & polimórfico \\
\hline 1.02 & bnlg1627 & polimórfico & 2.04 & bnlg166 & polimórfico \\
\hline 1.02 & bnlg1178 & monomórfico & 2.05 & dupssr21 & monomórfico \\
\hline 1.03 & phi001 & monomórfico & 2.05 & bnlg371 & monomórfico \\
\hline 1.03 & bnlg439 & monomórfico & 2.05 & bnlg180 & monomórfico \\
\hline 1.04 & bnlg652 & monomórfico & 2.06 & bnlg121 & monomórfico \\
\hline 1.04 & bnlg2238 & monomórfico & 2.06 & nc003 & polimórfico \\
\hline 1.04 & bnlg1016 & polimórfico & 2.07 & bnlg1045 & monomórfico \\
\hline 1.06 & bnlg421 & polimórfico & 2.07 & $\mathrm{mmc} 271$ & monomórfico \\
\hline 1.07 & bnlg615 & monomórfico & $2.07 / 2.08$ & mmc191 & monomórfico \\
\hline 1.08 & dupssr12 & monomórfico & 2.08 & phi127 & monomórfico \\
\hline 1.09 & phi055 & monomórfico & 2.08 & bnlg198 & monomórfico \\
\hline 1.09 & bnlg100 & monomórfico & 2.08 & dupssr25 & monomórfico \\
\hline 1.09 & phi011 & monomórfico & 2.08 & dupssr24 & monomórfico \\
\hline 1.09 & bnlg400 & monomórfico & 2.08 & phi90 & monomórfico \\
\hline 1.11 & bnlg504 & monomórfico & 2.09 & bnlg1520 & monomórfico \\
\hline 1.11 & bnlg131 & polimórfico & 3.04 & nc030 & monomórfico \\
\hline 1.11 & phi064 & monomórfico & 3.04 & bnlg602 & monomórfico \\
\hline 1.12 & bnlg257 & monomórfico & 3.04 & phi029 & monomórfico \\
\hline 2.01 & bnlg1092 & monomórfico & 3.05 & phi073 & polimórfico \\
\hline 2.02 & bnlg1017 & polimórfico & 3.05 & bnlg420 & monomórfico \\
\hline 2.02 & bnlg469 & monomórfico & 3.05 & phi053 & monomórfico \\
\hline 3.06 & dupssr23 & monomórfico & 5.01 & bnlg1836 & monomórfico \\
\hline 3.07 & bnlg197 & polimórfico & 5.01 & nc007 & monomórfico \\
\hline
\end{tabular}


Tabela 14. Relação dos primers testados para amplificação de locos microssatélites das linhagens DAS6 e DAS4

\begin{tabular}{|c|c|c|c|c|c|}
\hline Localização (BIN) & Loco SSR & Amplificação & Localização (BIN) & Loco SSR & Amplificação \\
\hline 4.00 & bnlg372 & polimórfico & 5.01 & bnlg143 & polimórfico \\
\hline 4.01 & phi072 & polimórfico & 5.02 & bnlg565 & polimórfico \\
\hline 4.03 & nc004 & polimórfico & 5.02 & phi113 & monomórfico \\
\hline 4.03 & phi021 & monomórfico & 5.02 & bnlg105 & monomórfico \\
\hline 4.04 & phi074 & monomórfico & 5.03 & bnlg557 & polimórfico \\
\hline 4.05 & nc005 & monomórfico & 5.03 & phi008 & monomórfico \\
\hline 4.05 & phi079 & monomórfico & 5.04 & dupssr10 & polimórfico \\
\hline 4.05 & phi026 & monomórfico & 5.04 & bnlg603 & monomórfico \\
\hline 4.05 & phi096 & polimórfico & 5.04 & bnlg653 & polimórfico \\
\hline 4.05 & bnlg667 & monomórfico & 5.05 & $\mathrm{mmc0} 282$ & monomórfico \\
\hline 4.05 & bnlg490 & monomórfico & $5.05-5.06$ & bnlg278 & polimórfico \\
\hline 4.06 & bnlg252 & não amplifica & 5.06 & bnlg609 & polimórfico \\
\hline 4.06 & bnlg1741 & polimórfico & 5.07 & bnlg118 & monomórfico \\
\hline 4.07 & bnlg1784 & monomórfico & 5.07 & bnlg1306 & polimórfico \\
\hline 4.07 & bnlg2291 & monomórfico & 5.09 & bnlg389 & monomórfico \\
\hline 4.07 & bnlg1189 & monomórfico & 5.09 & bnlg386 & monomórfico \\
\hline 4.07 & dupssr34 & monomórfico & 6.00 & bnlg238 & polimórfico \\
\hline 4.08 & phi093 & monomórfico & 6.00 & bnlg161 & monomórfico \\
\hline 4.08 & phi092 & monomórfico & 6.01 & bnlg249 & monomórfico \\
\hline 4.08 & dupssr28 & monomórfico & 6.01 & phi077 & monomórfico \\
\hline 4.09 & bnlg1589 & monomórfico & 6.01 & bnlg107 & monomórfico \\
\hline $4.09 / 4.10$ & bnlg1565 & monomórfico & 6.02 & bnlg1371 & monomórfico \\
\hline 4.11 & phi006 & monomórfico & 6.04 & nc009 & monomórfico \\
\hline 4.11 & phi019 & monomórfico & 6.04 & bnlg480 & monomórfico \\
\hline 4.11 & phi076 & monomórfico & 6.05 & phi078 & monomórfico \\
\hline 4.11 & bnlg589 & monomórfico & 6.05 & phi081 & monomórfico \\
\hline 5.00 & phi024 & monomórfico & 6.05 & nc012 & monomórfico \\
\hline 6.05 & phi025 & monomórfico & 8.09 & dupssr14 & monomórfico \\
\hline
\end{tabular}


Tabela 14. Relação dos primers testados para amplificação de locos microssatélites das linhagens DAS6 e DAS4

\begin{tabular}{|c|c|c|c|c|c|}
\hline Localização (BIN) & Loco SSR & Amplificação & Localização (BIN) & Loco SSR & Amplificação \\
\hline 6.06 & bnlg345 & monomórfico & 9.01 & phi068 & monomórfico \\
\hline 6.06 & dupssr15 & monomórfico & 9.01 & phi033 & monomórfico \\
\hline 6.06 & phi070 & monomórfico & 9.01 & phi028 & monomórfico \\
\hline 7.01 & bnlg1292 & monomórfico & 9.01 & phi067 & monomórfico \\
\hline 7.01 & phi112 & monomórfico & 9.02 & dupssr19 & monomórfico \\
\hline 7.01 & phi057 & monomórfico & 9.02 & dupssr6 & monomórfico \\
\hline 7.02 & phi034 & monomórfico & 9.02 & umc1033 & polimórfico \\
\hline 7.02 & bnlg657 & monomórfico & 9.02 & umc1037 & polimórfico \\
\hline 7.02 & phi114 & monomórfico & 9.02 & phi017 & monomórfico \\
\hline 7.02 & bnlg398 & monomórfico & 9.02 & bnlg244 & monomórfico \\
\hline 7.02 & dupssr9 & monomórfico & 9.03 & phi065 & monomórfico \\
\hline 7.03 & bnlg434 & monomórfico & 9.03 & phi022 & polimórfico \\
\hline $7.03 / 7.06$ & bnlg339 & monomórfico & 9.03 & phi027 & polimórfico \\
\hline 7.04 & bnlg155 & monomórfico & 9.03 & phi061 & polimórfico \\
\hline 7.04 & bnlg1161 & monomórfico & $9.03-9.04$ & $\mathrm{mmc0051}$ & monomórfico \\
\hline 7.04 & dupssr13 & monomórfico & 9.04 & phi042 & monomórfico \\
\hline 7.05 & phi082 & monomórfico & 9.06 & bnlg292a & monomórfico \\
\hline 8.03 & dupssr3 & monomórfico & 9.07 & bnlg279 & monomórfico \\
\hline 8.03 & bnlg669 & monomórfico & $9.07-9.08$ & bnlg619 & monomórfico \\
\hline 8.03 & phi115 & polimórfico & 10.02 & phi059 & monomórfico \\
\hline 8.03 & phi015 & monomórfico & 10.03 & bnlg210 & polimórfico \\
\hline 8.04 & bnlg119 & monomórfico & 10.03 & bnlg640 & polimórfico \\
\hline 8.04 & phi060 & não amplifica & 10.04 & phi084 & monomórfico \\
\hline 8.04 & phi014 & polimórfico & 10.06 & bnlg594 & monomórfico \\
\hline 8.05 & bnlg666 & polimórfico & $10.06-10.07$ & bnlg153 & monomórfico \\
\hline 8.05 & bnlg162 & polimórfico & 10.07 & bnlg153 & monomórfico \\
\hline 8.06 & bnlg240 & Monomórfico & & & \\
\hline
\end{tabular}


O cromossomo 5 é o que apresentou maior número de locos microssatélites polimórficos, especialmente na região compreendida entre os bins 5.04 e 5.06. O cromossomo 7, por sua vez, não apresentou polimorfismo em nenhum loco microssatélite.

Nenhum par de primers SSR revelou polimorfismo entre bulks. Esse resultado é um indicativo de que nenhuma das regiões amplificadas pelos primers testados se encontra a menos de $30 \mathrm{cM}$ do gene de resistência (Michelmore, 1991) ou que QRLs próximos a essas regiões apresentam pequeno efeito fenotípico (Lynch e Walsh, 1998) que não puderam ser detectados.

Os 141 indivíduos da população $\mathrm{F}_{1} \mathrm{RC}_{1}$ foram genotipados para aproximadamente dois marcadores SSR por cromossomo (Figura 6), com exceção dos cromossomos 6 e 7. Este marcadores foram utilizados na análise de ligação visando à localização cromossômica dos grupos de ligação de marcadores AFLP.

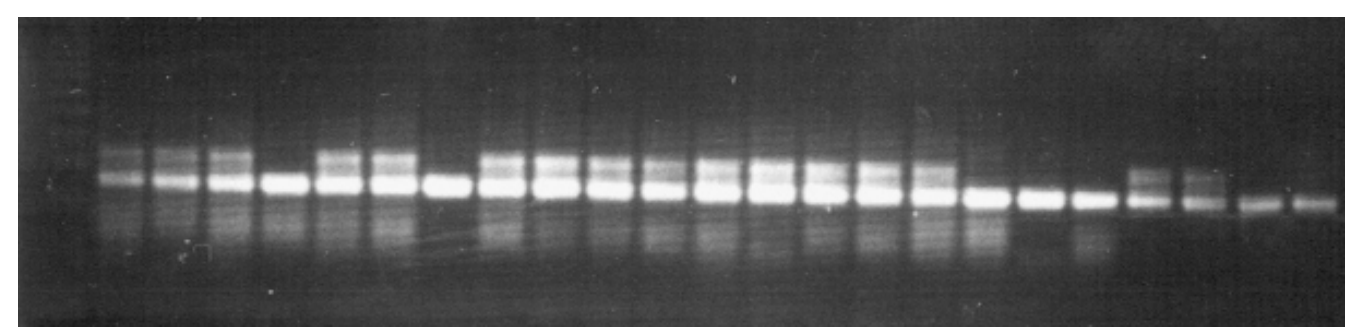

Figura 6 - Produto da amplificação de indivíduos resistentes a C. graminicola com o primer bnlg666

\subsubsection{Análise de marcadores AFLP}

Das 89 combinações de primers AFLP testadas, oitenta e quatro revelaram polimorfismos entre genitores (Tabela 15). O número de locos polimórficos variou de um a quinze, com média aproximada de 7 por 
combinação de primer. Considerando todas as combinações testadas, foram encontrados 557 locos polimórficos num total de 3469 locos analisados, ou seja, $16 \%$ de polimorfismo. A porcentagem de polimorfismo encontrada neste trabalho também foi inferior à de 31,3\% relatada por Lopes (2003), porém superior à relatada por Castiglioni et al. (1999), que encontrou $14,9 \%$ usando combinações de primers EcoRI/Msel. Vinte e seis combinações de primers revelaram polimorfismos entre bulks, totalizando 29 locos. Destas combinações, 10 foram analisadas nos 141 indivíduos da população $F_{1} R C_{1}$, totalizando 45 locos dentre os quais 13 revelaram polimorfismos entre bulks (Figura 7).

Tabela 15. Combinações de primers AFLP testadas com respectivos números de locos analisados e de locos polimórficos

\begin{tabular}{ccccc}
\hline $\begin{array}{c}\text { Combinações } \\
\text { de primers }\end{array}$ & $\begin{array}{c}\text { Código de } \\
\text { identificação }\end{array}$ & $\begin{array}{c}\text { Número total } \\
\text { de locos }\end{array}$ & $\begin{array}{c}\text { Polimórficos } \\
\text { entre genitores }\end{array}$ & $\begin{array}{c}\text { Polimórficos } \\
\text { entre bulks }\end{array}$ \\
\hline EAAAMCAA & E31M47 & 74 & 14 & - \\
EAAAMCAC & E31M48 & 39 & 10 & - \\
EAAAMCAG & E31M49 & 67 & 10 & 2 \\
EAAAMCGC & E31M56 & 31 & 3 & - \\
EAAAMCGT & E31M58 & 33 & 3 & - \\
EAAAMCTA & E31M59 & 97 & 15 & 1 \\
EAAAMCTC & E31M60 & 42 & 5 & - \\
EAAAMCTG & E31M61 & 58 & 2 & - \\
EAAAMCTT & E31M62 & 100 & 11 & - \\
EAACMCAA & E32M47 & 41 & 1 & - \\
EAACMCAC & E32M48 & 25 & 10 & 2 \\
EAACMCAG & E32M49 & 35 & 5 & - \\
EAACMCAT & E32M50 & 60 & 10 & - \\
EAACMCGC & E32M56 & 30 & 5 & - \\
EAACMCGT & E32M58 & 22 & 2 & - \\
EAACMCTA & E32M59 & 48 & 7 & - \\
EAACMCTC & E32M60 & 48 & 14 & - \\
EAACMCTG & E32M61 & 49 & 4 & - \\
EAACMCTT & E32M62 & 54 & 7 & - \\
EAAGMCAA & E33M47 & 43 & 4 & - \\
EAAGMCAC & E33M48 & 30 & 10 & - \\
EAAGMCAG & E33M49 & 33 & 5 & 1 \\
EAAGMCAT & E33M50 & 65 & 6 & \\
EAAGMCGC & E33M56 & 21 & 3 &
\end{tabular}


Tabela 15. Combinações de primers AFLP testadas com respectivos números de locos analisados e de locos polimórficos

\begin{tabular}{|c|c|c|c|c|}
\hline $\begin{array}{l}\text { Combinações } \\
\text { de primers }\end{array}$ & $\begin{array}{l}\text { Código de } \\
\text { identificação }\end{array}$ & $\begin{array}{l}\text { Número total } \\
\text { de locos }\end{array}$ & $\begin{array}{l}\text { Polimórficos } \\
\text { entre genitores }\end{array}$ & $\begin{array}{l}\text { Polimórficos } \\
\text { entre bulks }\end{array}$ \\
\hline EAAGMCGT & E33M58 & 27 & 1 & 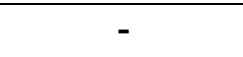 \\
\hline EAAGMCTA & E33M59 & 51 & 10 & - \\
\hline EAAGMCTC & E33M60 & 55 & 13 & - \\
\hline EAAGMCTG & E33M61 & 42 & 5 & 1 \\
\hline EAAGMCTT & E33M62 & 44 & 5 & - \\
\hline EACCMCAA & E36M47 & 39 & 6 & 1 \\
\hline EACCMCAC & E36M48 & 23 & 4 & - \\
\hline EACCMCAG & E36M49 & 27 & 8 & 1 \\
\hline EACCMCAT & E36M50 & 40 & 6 & - \\
\hline EACCMCGC & E36M56 & 25 & 4 & 1 \\
\hline EACCMCGT & E36M58 & 21 & 4 & - \\
\hline EACCMCTA & E36M59 & 41 & 8 & - \\
\hline EACCMCTC & E36M60 & 43 & 4 & 1 \\
\hline EACCMCTG & E36M61 & 29 & 4 & - \\
\hline EACCMCTT & E36M62 & 37 & 4 & - \\
\hline EACGMCAA & E37M47 & 38 & 3 & - \\
\hline EACGMCAC & E37M48 & 18 & 6 & - \\
\hline EACGMCAG & E37M49 & 24 & 3 & - \\
\hline EACGMCAT & E37M50 & 39 & 4 & - \\
\hline EACGMCGC & E37M56 & 25 & nd & - \\
\hline EACGMCGT & E37M58 & 26 & 9 & - \\
\hline EACGMCTC & E37M60 & 24 & 7 & 1 \\
\hline EACGMCTG & E37M61 & 31 & 8 & - \\
\hline EACGMCTT & E37M62 & 34 & 7 & - \\
\hline EACTMCAA & E38M47 & 40 & 6 & - \\
\hline EACTMCAC & E38M48 & 28 & 8 & 1 \\
\hline EACTMCAG & E38M49 & 35 & 6 & 1 \\
\hline ЕАСТMCAT & E38M50 & 48 & 6 & - \\
\hline EACTMCGC & E38M56 & 28 & 4 & 1 \\
\hline EACTMCGT & E38M58 & 18 & 3 & 1 \\
\hline EACTMCTC & E38M60 & 50 & 12 & 1 \\
\hline EACTMCTG & E38M61 & 35 & 2 & - \\
\hline EAGAMCAA & E39M47 & 87 & 8 & - \\
\hline EAGAMCAC & E39M48 & 42 & 7 & - \\
\hline EAGAMCAG & E39M49 & 51 & 7 & 1 \\
\hline EAGAMCAT & E39M50 & 77 & 11 & 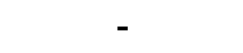 \\
\hline EAGAMCGC & E39M56 & 25 & 5 & - \\
\hline EAGAMCGT & E39M58 & 30 & 7 & - \\
\hline EAGAMCTC & E39M60 & 49 & 13 & - \\
\hline EAGAMCTG & E39M61 & 49 & 8 & 1 \\
\hline
\end{tabular}


Tabela 15. Combinações de primers AFLP testadas com respectivos números de locos analisados e de locos polimórficos

\begin{tabular}{ccccc}
\hline $\begin{array}{c}\text { Combinações } \\
\text { de primers }\end{array}$ & $\begin{array}{c}\text { Código de } \\
\text { identificação }\end{array}$ & $\begin{array}{c}\text { Número total } \\
\text { de locos }\end{array}$ & $\begin{array}{c}\text { Polimórficos } \\
\text { entre genitores }\end{array}$ & $\begin{array}{c}\text { Polimórficos } \\
\text { entre bulks }\end{array}$ \\
\hline EAGAMCTT & E39M62 & 73 & 20 & - \\
EACCMCAA & E40M47 & 43 & 6 & - \\
EAGCMCAC & E40M48 & 30 & 6 & - \\
EAGCMCAG & E40M49 & 34 & 4 & - \\
EAGCMCAT & E40M50 & 39 & 3 & - \\
EAGCMCGC & E40M56 & 16 & 3 & - \\
EAGCMCGT & E40M58 & 30 & 5 & - \\
EAGCMCTC & E40M60 & 49 & 7 & 1 \\
EAGCMCTG & E40M61 & 43 & 12 & 1 \\
EAGGMCAA & E41M47 & 34 & - & - \\
EAGGMCAC & E41M48 & 27 & nd & - \\
EAGGMCAG & E41M49 & 36 & 2 & - \\
EAGGMCAT & E41M50 & 46 & 4 & - \\
EAGGMCGC & E41M56 & 22 & 1 & - \\
EAGGMCGT & E41M58 & 34 & 5 & - \\
EAGGMCTC & E41M60 & 37 & 6 & 2 \\
EAGGMCTG & E41M61 & 42 & 12 & - \\
EACAMCAA & E44M47 & 30 & 12 & - \\
EACAMCAC & E44M48 & 34 & 8 & - \\
EACAMCAG & E44M49 & 33 & 2 & - \\
EACAMCAT & E44M50 & 63 & 11 & - \\
EACAMCGC & E44M56 & 14 & nd & - \\
EACAMCGT & E44M58 & 27 & nd & - \\
EACAMCTC & E44M60 & 45 & 8 & - \\
EACAMCTG & E44M61 & 41 & 8 & - \\
\hline EAMAM & & 5 & - \\
\hline
\end{tabular}

nd: não disponível devido a não amplificação do genitor suscetível 
População segregante

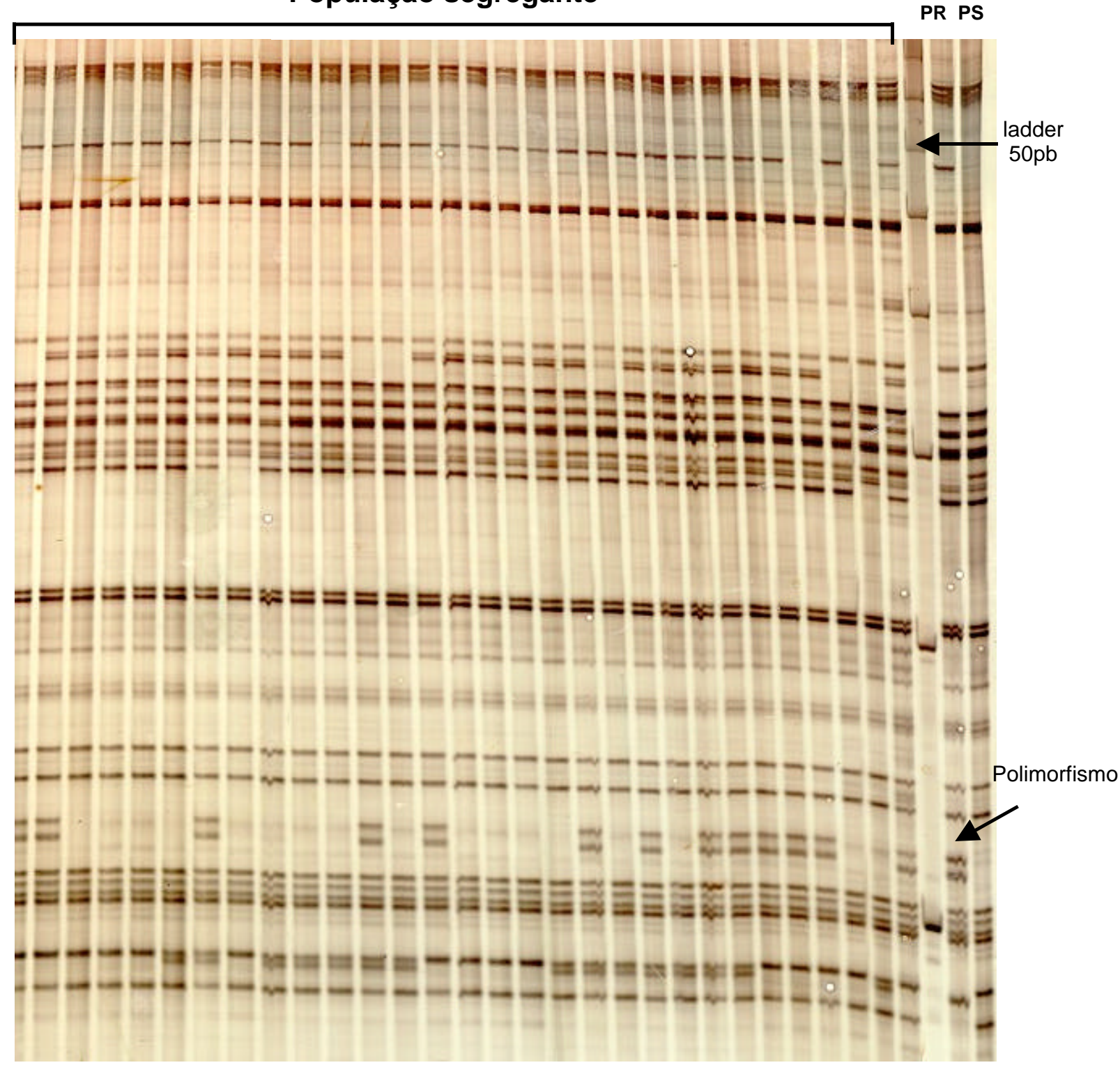

Figura 7 - Amostra de fragmentos AFLP gerados com a combinação de primer E32M48 mostrando presença e ausência de bandas na linhagem resistente (PR), suscetível (PS) e segregação na população $F_{1} R C_{1}$ 


\subsubsection{Análise de marcas simples e construção do mapa de ligação}

Os testes de aderência ao modelo de segregação Mendeliana das proporções genotípicas dos 62 locos polimórficos (17 SSRs e 45 AFLPs) detectaram sete marcadores distorcidos (1 SSR e 6 AFLPs), os quais foram descartados das análises posteriores. As causas para um marcador não apresentar segregação mendeliana são: a) erro tipo I, ou seja, considerar que um marcador não tem segregação mendeliana quando, na realidade, ele tem; b) falso polimorfismo na ausência, ou seja, bandas que na verdade são monomórficas e apresentam polimorfismo devido a falhas nas reações, não por razões genéticas; c) falso polimorfismo na presença (bandas fantasma), ou seja, bandas que na verdade não são devidas ao material genético em análise e sim a impurezas nos componentes da reação, levando ao aparecimento esporádico das bandas; d) efeito de seleção sobre a característica ligada a este marcador (Melo, 2000).

Análises de regressão linear simples foram realizadas para testar a significância da associação entre QRLs e marcadores (Tabela 16). Dezenove marcadores foram significativos pela análise de regressão linear simples no primeiro experimento, 15 marcadores no segundo e 18 na análise conjunta. Treze marcadores foram significativos nos dois experimentos, sendo que destes 11 haviam revelado polimorfismos entre os bulks. Os marcadores identificados pela análise de regressão linear simples foram alocados em cinco grupos de ligação pelo software MapMaker/EXP 3.0b (Figura 8).

A ordenação e determinação da localização cromossômica dos marcadores AFLPs foram realizadas de acordo com o posicionamento de marcadores microssatélites no mapa genético público de milho (Senior et al., 1996). Apenas os marcadores E31M49-151 e Bnlg143 não foram incluídos em nenhum grupo de ligação. É interessante observar que apenas marcadores do cromossomo 10 haviam revelado polimorfismos entre bulks. Este resultado 
indica que a BSA não foi capaz de detectar alguns QRLs. De fato, a análise só detectou regiões no cromossomo $10 \mathrm{com}$ maior efeito na resistência, o que confirma que a BSA é uma técnica limitada para identificar QTLs de pequeno efeito (Lynch \& Wash, 1998).

Tabela 16. Coeficiente de regressão que representa o efeito estimado dos marcadores significativamente associados com a resistência a antracnose foliar com base na análise de regressão linear simples

\begin{tabular}{|c|c|c|c|c|}
\hline \multirow{2}{*}{ Cromossomo } & \multirow{2}{*}{ Marcador } & \multicolumn{3}{|c|}{ Efeito } \\
\hline & & Experimento 1 & Experimento 2 & Conjunta \\
\hline 2 & Bnlg166 & $-0,32^{\star \star}$ & - & $-0,32^{*}$ \\
\hline 2 & E32M59-203 & $-0,30^{\star *}$ & - & $-0,32^{*}$ \\
\hline 2 & Nc003 & $-0,31^{* *}$ & - & $-0,33^{*}$ \\
\hline 3 & Phi073 & $-0,35^{*}$ & - & 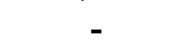 \\
\hline 3 & Bnlg197 & $-0,33^{\star *}$ & $-0.48^{*}$ & $-0,41^{\star *}$ \\
\hline 3 & E31M49-95 & $-0,25^{*}$ & - & - \\
\hline 5 & Bnlg143 & . & $0,43^{*}$ & $0,30^{*}$ \\
\hline 9 & E44M47-450 & $-0,22^{*}$ & - & - \\
\hline 10 & E38M48-236 & $-0,41^{* * *}$ & $-0,67^{\star \star *}$ & $-0,54^{\star * *}$ \\
\hline 10 & $\mathrm{E} 44 \mathrm{M} 47-227^{\mathrm{a}}$ & $-0,41^{* * *}$ & $-0,65^{\star * *}$ & $-0,53^{\star * *}$ \\
\hline 10 & E32M59-89a & $-0,41^{\star \star \star}$ & $-0,66^{\star \star \star}$ & $-0,53^{\star \star \star}$ \\
\hline 10 & Bnlg210 & $-0,44^{\star * *}$ & $-0,63^{\star *}$ & $-0,54^{\star * *}$ \\
\hline 10 & E32M48-163 & $-0,42^{\star \star \star}$ & $-0,70^{\star \star \star}$ & $-0,56^{\star * *}$ \\
\hline 10 & E32M60-165 & $-0,39^{* * *}$ & $-0,63^{\star \star *}$ & $-0,51^{* * *}$ \\
\hline 10 & $\mathrm{E} 44 \mathrm{M} 47-263^{\mathrm{a}}$ & $-0,39^{\star * *}$ & $-0,66^{* * *}$ & $-0,52^{\star * *}$ \\
\hline 10 & E36M49-221 & $-0,42^{\star \star \star}$ & $-0,73^{\star \star \star}$ & $-0,57^{\star \star \star}$ \\
\hline 10 & E36M60-90 & $-0,40^{\star * *}$ & $-0,69^{\star *}$ & $-0,55^{\star \star \star}$ \\
\hline 10 & E33M61-210 & $-0,33^{* *}$ & $-0,50^{*}$ & $-0,41^{* * *}$ \\
\hline 10 & E41M49-251 & $-0,44^{\star * *}$ & $-0,66^{\star * *}$ & $-0,55^{\star * *}$ \\
\hline 10 & E31M49-624 & $-0,40^{* * *}$ & $-0,69^{* \star *}$ & $-0,55^{\star * *}$ \\
\hline$N A^{b}$ & E31M49-151 & - & $0,52^{*}$ & $0,37^{*}$ \\
\hline
\end{tabular}



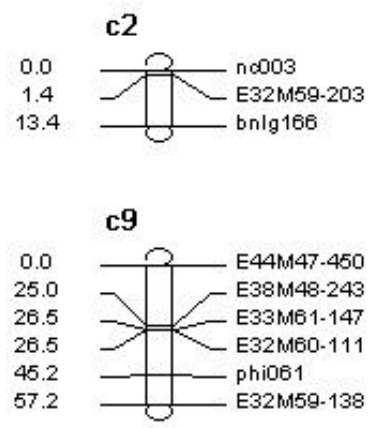

c3
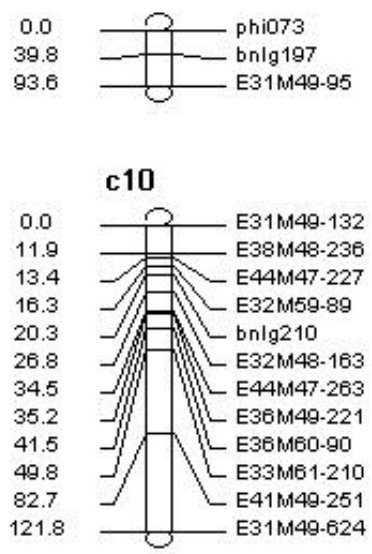

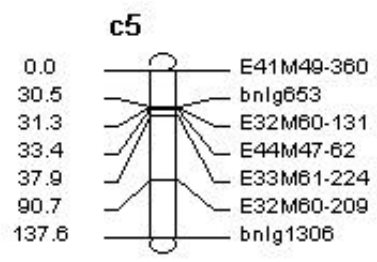

Figura 8 - Mapa genético dos cromossomos (c) contendo marcadores significativamente associados a QRLs pela análise de regressão linear simples

\subsubsection{Análise de regressão linear múltipla}

A análise de regressão linear múltipla identificou três marcadores associados a QRLs em cada experimento. A porcentagem da variação fenotípica explicada pelos modelos foi de $25,7 \%, 23,3 \%$ e $24,4 \%$ para os experimentos 1 e 2 e análise conjunta, respectivamente (Tabela 17). Entre os marcadores associados a QRLs, apenas o Bnlg197, localizado no cromossomo 3, foi identificado em todos os experimentos. Dois marcadores (E32M59-89 e E36M49-221) associados a QRLs e localizados no cromossomo 10 foram identificados. Como foram detectados em experimentos diferentes, infere-se que estes marcadores podem estar associados a QRLs diferentes e específicos para cada ambiente. O marcador E36M49-221 foi associado a QRLs tanto no segundo experimento quanto na média dos experimentos. Um marcador localizado no cromossomo 2, nc003, foi significativo apenas no primeiro experimento. Por outro lado, um marcador localizado no cromossomo 5, bnlg143, foi significativo no segundo experimento e na média dos experimentos. 
Os valores de $R^{2}$ parcial representam a proporção da variação fenotípica explicada por cada marcador. Como estes valores foram pequenos para os marcadores localizados nos cromossomos 2 (nc003), 3 (bnlg197) e 5 (bnlg143), os mesmos devem estar ligados a QRLs de pequeno efeito fenotípico ou distantes dos mesmos.

Tabela 17. Cromossomo, loco marcador, porcentagem da variação fenotípica explicada pelo marcador $\left(R^{2}\right)$ e efeito estimado do alelo marcador baseado na análise de regressão linear múltipla para severidade de antracnose foliar

\begin{tabular}{|c|c|c|c|c|c|}
\hline Expto. & Crom. & Marcador & Efeito & Erro padrão & $\mathrm{R}^{2}$ parcial (\%) \\
\hline \multirow[t]{3}{*}{ E1 } & 2 & $\mathrm{Nc003}$ & $-0,29$ & 0,13 & 4,10 \\
\hline & 3 & Bnlg197 & $-0,30$ & 0,13 & 5,94 \\
\hline & 10 & E32M59-89 & $-0,45$ & 0,12 & 15,61 \\
\hline \multicolumn{6}{|c|}{$\mathrm{R}^{2}$ do modelo $=25,65 \%$} \\
\hline \multirow[t]{3}{*}{ E2 } & 3 & Bnlg197 & $-0,48$ & 0,22 & 3,82 \\
\hline & 5 & Bnlg143 & 0,64 & 0,22 & 6,23 \\
\hline & 10 & E36M49-221 & $-0,87$ & 0,22 & 13,26 \\
\hline \multicolumn{6}{|c|}{$\mathrm{R}^{2}$ do modelo $=23,30 \%$} \\
\hline \multirow[t]{4}{*}{ Conjunta } & 3 & Bnlg197 & $-0,39$ & 0,16 & 4,41 \\
\hline & 5 & Bnlg143 & 0,47 & 0,16 & 6,13 \\
\hline & 10 & E36M49-221 & $-0,67$ & 0,16 & 13,81 \\
\hline & \multicolumn{5}{|c|}{$\mathrm{R}^{2}$ do modelo $=24,35 \%$} \\
\hline
\end{tabular}

A origem parental do alelo de resistência foi determinada pelo sinal do coeficiente de regressão que determina o efeito do QRL. Sendo o sinal negativo (redução da severidade de doença), infere-se que o alelo de resistência foi oriundo do genitor resistente. Sendo o sinal positivo (aumento da severidade de doença), infere-se que o alelo de resistência descendeu do genitor suscetível. 
No presente trabalho, apenas o alelo associado a bnlg143, localizado no cromossomo 5 , teve sua origem no genitor suscetível, sendo os demais oriundos do genitor resistente. A identificação de um alelo dominante de resistência ou suscetibilidade proveniente do genitor suscetível só é possível, no caso de retrocruzamentos, quando se utilizam marcadores codominantes, que é o caso do bnlg143. Apenas um marcador codominante permite distinguir entre a classe homozigótica para o alelo dominante e a classe heterozigótica, as quais segregam na população quando o alelo de resistência for proveniente do genitor suscetível (recorrente).

O procedimento stepwise seleciona as variáveis regressoras (marcadores) procurando o melhor modelo de regressão através da exclusão de marcadores com informação redundante, ou seja, que apresentam alta correlação (Silva \& Vencovsky, 2002). Assim, espera-se que cada marcador que entra no modelo deva estar associado a um QRL diferente. Porém, entre avaliações, os marcadores presentes no modelo podem ser alterados, seja porque existem QRLs com efeito importante apenas em determinado ambiente ou porque a associação de um marcador a um QRL em uma situação é menos significativa do que a associação do mesmo QRL a outro marcador próximo em outro ambiente (Lopes, 2003).

Apenas a associação entre QRL e marcador bnlg197, localizado no bin 3.07, apesar de corresponder a um pequeno fenotípico, não sofreu influência do ambiente, pois foi significativa em ambos experimentos. Nesta região, também foram mapeados QRLs para o vírus do mosaico comum do milho (Pernet et al., 1999) e para $H$. turcicum (Welz et al., 1999; Freymark et al., 1994). Na realidade, os sintomas foliares de $H$. turcicum são similares aos sintomas causados por C. graminicola. Além disso, a reação de resistência em folhas de milho, geralmente envolve estímulo a biossíntese de compostos fenólicos, especialmente fenilpropanóides (Bergstrom \& Nicholson, 1999). Estas 
informações sugerem que os QRLs para $H$. turcicum e C. graminicola podem ser os mesmos.

Os QRLs ligados a nc003, localizado no bin 2.06, e bnlg143, localizado no bin 5.01, foram detectados em apenas um dos experimentos, indicando a presença de interação destes QRLs com o ambiente. Nestas duas regiões, também foram mapeados QRLs para H. turcicum (Welz et al., 1999; Freymark et al., 1994) reforçando a hipótese de uma possível rota metabólica comum discutida anteriormente.

Duas regiões possivelmente associadas a dois QRLs foram identificadas no cromossomo 10 em experimentos diferentes. Como os marcadores E32M5989 e E36M49-221 encontram-se a aproximadamente 19 cM de distância e há informações na literatura da presença de dois clusters de genes de resitência no cromossomo 10 (Tabela 1) pode-se inferir a presença de QRLs específicos para cada ambiente neste cromossomo.

\subsubsection{Mapeamento por intervalo composto}

A metodologia de regressão linear múltipla, apesar de ser uma análise simples, apresenta uma baixa precisão na detecção de QTLs, principalmente quando dois QTLs estão localizados no mesmo grupo de ligação (Zeng, 1994). Desta forma, para aumentar o poder de detecção de QTLs e a precisão das estimativas do efeito e da posição dos mesmos, utilizou-se o método de mapeamento por intervalo composto proposto por Zeng (1993) e por Jansen (1993).

O mapeamento por intervalo composto foi realizado com base no mapa de ligação dos cromossomos 2, 3, 5, 9 e 10 (Figura 9). Marcadores localizados no cromossomo 10 (c10) mostraram os maiores valores de LOD, além de terem sido os únicos marcadores identificados pela BSA. As curvas de LOD dos dois experimentos e da análise conjunta não se apresentaram paralelas no 
cromossomo 10, indicando que as estimativas dos efeitos genéticos dos QRLs foram influenciadas pelo ambiente. Dois picos de valores de LOD acima de $3 \mathrm{e}$ distintos, no cromossomo 10, permitem inferir que há pelo menos dois QRLs localizados neste cromossomo (QRL1 e QRL2) (Tabela 18). Há dois picos menos evidentes nos valores de LOD neste mesmo cromossomo, os quais podem ser interpretados como devido à presença de dois outros QRLs (QRL3 e QRL4). Entretanto, esta afirmação é apenas uma suposição, uma vez que os mesmos se encontram em intervalos muito próximos ao QRL2, que apresentou um valor de LOD mais expressivo. O mapa de ligação deste cromossomo foi construído com doze marcadores abrangendo uma extensão de $122 \mathrm{cM}$. A porcentagem da variação fenotípica explicada pelos QRLs individuais variou de $9,6 \%$ a $21,0 \%$. Cumulativamente, os QRLs explicaram $28,9 \%$, 32,3\% e $31,0 \%$ da variância fenotípica no experimento 1, experimento 2 e análise conjunta, respectivamente. Estes valores foram semelhantes aos encontrados pela análise de regressão múltipla. Como a maior parte da variância fenotípica observada para este caráter foi devida a fatores genéticos $\left(\hat{h}_{\mathrm{a}}^{2}=85,9\right.$ a $\left.91,7 \%\right)$, outras regiões genômicas também devem estar ligadas a genes de resistência à antracnose foliar, as quais não foram detectadas neste estudo. Uma possível explicação para os baixos valores de $\mathrm{R}^{2}$ encontrados é o fato de ter-se utilizado o delineamento genético de retrocruzamento juntamente com um marcador genético que apresenta segregação dominante para a realização do mapeamento. Este tipo de situação impede a identificação de alelos dominantes tanto de resistência como de suscetibilidade provenientes do genitor suscetível, uma vez que não é possível distinguir indivíduos homozigóticos para o alelo dominante dos indivíduos heterozigóticos. Outra limitação do delineamento genético de retrocruzamentos é a estimação apenas dos efeitos aditivos dos QRLs, não sendo estimados os efeitos de dominância e grau de dominância. Todos os QRLs identificados apresentaram efeitos aditivos negativos, contribuindo para a redução da severidade de doença, sendo provenientes do 
genitor resistente. Efeitos aditivos negativos também foram encontrados na análise de modelos de herança mista apresentada no item 4.1.3 para o gene de efeito maior.

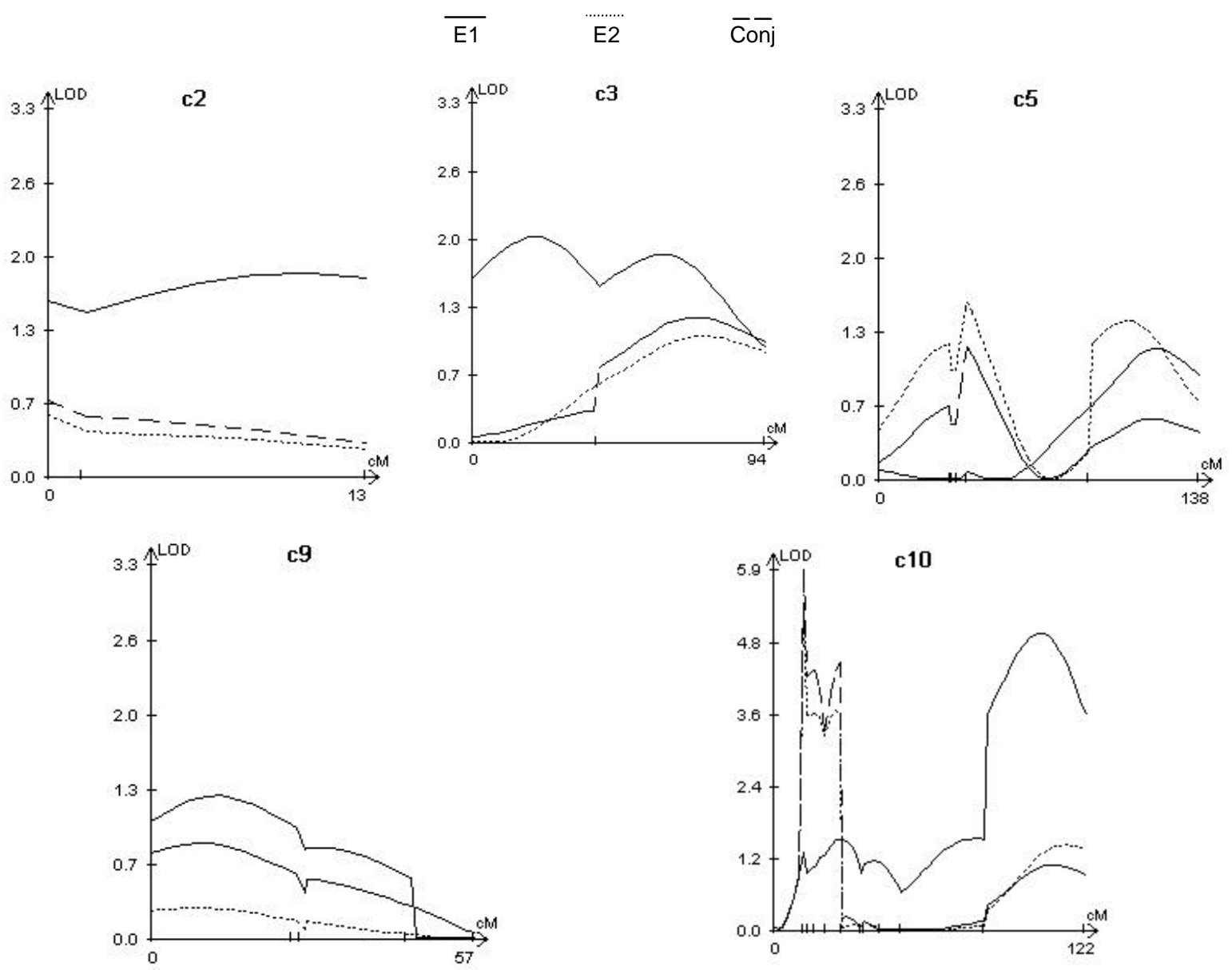

Figura 9 - Resultado do mapeamento por intervalo composto de QRLs para antracnose foliar em milho. As curvas representam o valor LOD calculado a cada $2 \mathrm{cM}$

É interessante salientar que a metodologia de mapeamento por intervalo composto permitiu individualizar os QRLs presentes no cromossomo 10. Análises menos refinadas, como o modelo de herança mista, indicaram a 
presença de um único gene de efeito maior. Na realidade, estes QRLs (QRL1 e QRL2) se comportaram como monogenes, uma vez que foram identificados em ambientes diferentes. Já o QRL3 e o QRL4, caso não sejam falsos positivos, se encontram muito próximos ao QRL2. Esta proximidade genética faz com que haja pouca recombinação entre eles, permitindo que os mesmos sejam herdados conjuntamente com se fossem um único gene.

Tabela 18. Localização cromossômica, LOD score, proporção da variação fenotípica explicada pelo $Q R L$ e efeito aditivo dos QRLs detectados pelo mapeamento por intervalo composto

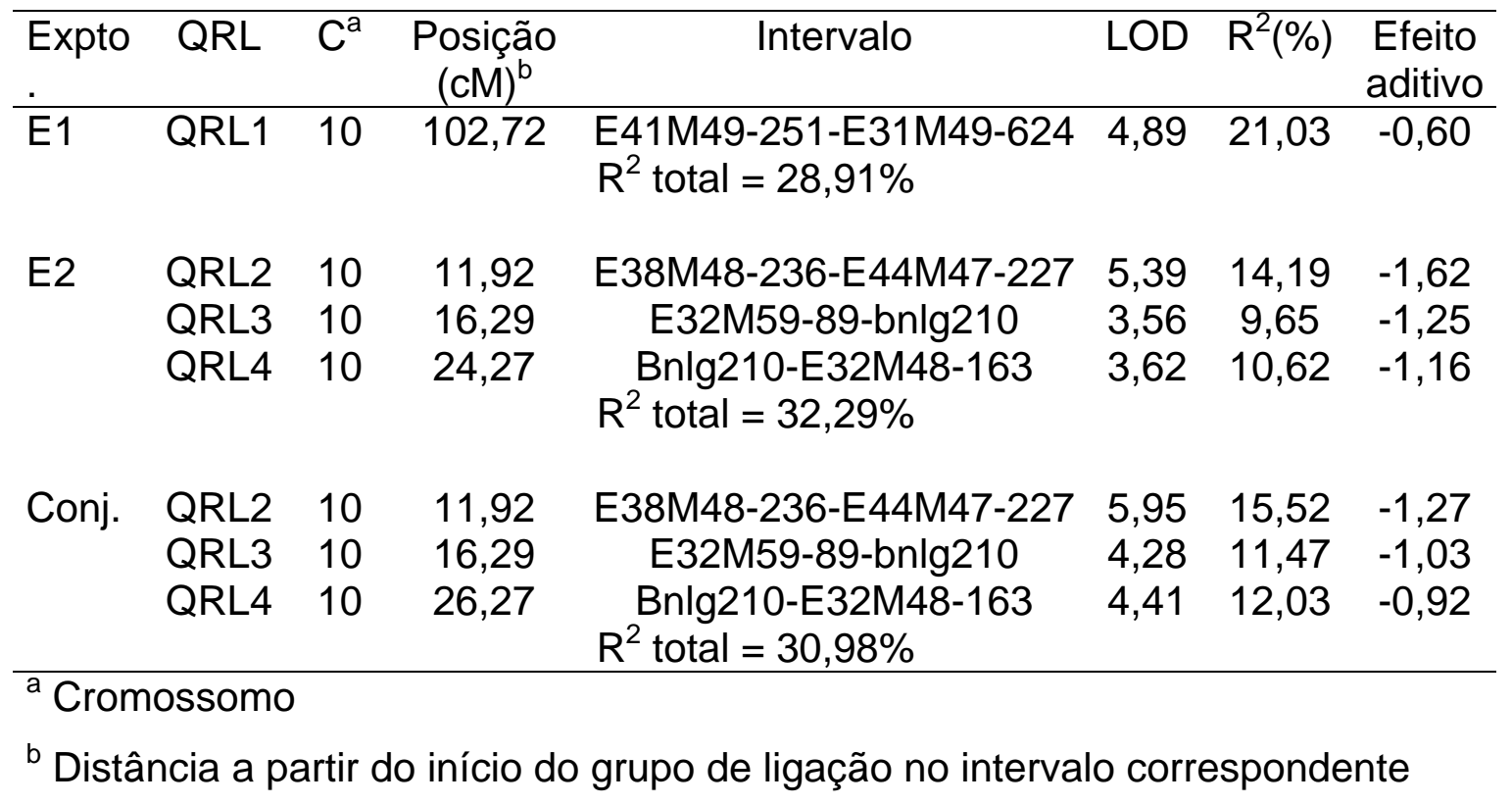

Há dois clusters de genes de resistência no cromossomo 10 situados nos bins 10.01 e 10.05 (Tabela 1). Genes de resistência à ferrugem comum e ferrugem polysora foram mapeados no bin 10.01 (Coe et al., citados por McMullen \& Simcox, 1995). Um gene de resistência ao mosaico comum do milho (Coe et al., citados por McMullen \& Simcox, 1995) e QRLs para cercosporiose (Bubeck et al., 1993), mosaico comum (Pernet et al., 1999) e podridão por Fusarium (Pè et al., 1993) foram mapeados no bin 10.05 . 
Sabendo-se que um bin corresponde à cerca de $20 \mathrm{cM}$ (McMullen \& Simcox, 1995) e conhecendo a posição dos QRLs identificados, é possível inferir a posição aproximada dos mesmos. O marcador bnlg210 (bin 10.03) encontra-se a 20,26 cM a partir do primeiro marcador do grupo de ligação do cromossomo 10 (E31M49-132). Portanto, o QRL1 pode estar localizado nos bins 10.07 ou 10.08, os QRLs 2 e 3, nos bins 10.02 ou 10.03 e o QRL4, nos bins 10.03 ou 10.04. Uma vez que o tamanho do bin pode variar de acordo com a população utilizada, as inferências sobre a localização dos QRLs são apenas aproximações. Entretanto, esta informação é importante para a seleção de microssatélites visando à saturação destas regiões para identificar marcadores mais próximos aos QRLs. Assim, podem-se obter estimativas mais precisas dos seus efeitos, aumentando a chance de sucesso na clonagem dos QRLs e a eficiência da seleção assistida (Lopes, 2003).

Comparando-se os resultados da análise de regressão linear múltipla (RLM) com o mapeamento por intervalo composto (MIC), pode-se verificar que a RLM foi capaz de detectar três QRLs de pequeno efeito fenotípico localizados nos cromossomos 2, 3 e 5, os quais não foram detectados pelo MIC. Por outro lado, o MIC detectou quatro QRLs localizados no cromossomo 10, tendo a RLM detectado apenas dois QRLs neste cromossomo. A maior precisão do MIC na detecção de QRLs localizados no mesmo grupo de ligação se deve ao fato desta abordagem analisar cada cM do mapa, controlando as interferências dos QRLs ligados. Vale lembrar que no presente trabalho esta análise foi realizada a cada $2 \mathrm{cM}$.

Outra importante constatação deste trabalho é a limitação do delineamento de retrocruzamentos aliado à utilização de marcadores com segregação dominante, combinação esta que, além de não permitir a detecção de QRLs do genitor suscetível, não estima dos efeitos de dominância dos QRLs. Por outro lado, o poder de detecção e a precisão das estimativas obtidas utilizando marcadores dominantes e retrocruzamentos são superiores quando 
comparados à utilização de marcadores dominantes e populações $F_{2}$, o que pode ser observado pela concordância dos valores de $R^{2}$ obtidos pela RLM e MIC. Quando se utiliza populações $F_{2}$ e marcadores dominantes, o mapeamento é baseado em dados incompletos dos genótipos marcadores, pois das nove classes possíveis a partir da combinação de dois locos, somente quatro podem ser diferenciadas $\left(M_{1} \_M_{2}, M_{1} \_m_{2} m_{2}, m_{1} m_{1} M_{2}\right.$, e $\left.m_{1} m_{1} m_{2} m_{2}\right)$ (Liu, 1998). De acordo com Jiang \& Zeng, citados por Lopes (2003), o poder de detecção e a precisão das estimativas dos parâmetros do QTL decrescem com o aumento de genótipos com informação perdida ou parcial. Desta forma, o máximo de informação genética de um trabalho de mapeamento é obtido a partir da associação de populações $F_{2}$ e marcadores com segregação codominante. Entretanto, o custo para saturar o genoma com estes marcadores é alto para os padrões de muitos laboratórios, ao passo que a técnica de marcadores AFLP é mais rápida e apresenta um custo por loco inferior aos microssatélites. Desta forma, o uso associado de marcadores microssatélites, em posições estratégicas, e marcadores AFLPs apresenta-se como uma alternativa interessante para saturar rapidamente o genoma e orientar na seleção de outros marcadores microssatélites para as regiões específicas onde se encontram os QRLs.

As duas estratégias de detecção de QRLs aplicadas neste estudo identificaram a presença de QRLs no cromossomo 10 e confirmaram que o caráter tem herança oligogênica, sendo fortemente influenciado pelo ambiente. Estes resultados concordam tanto com a análise de modelos de herança mista quanto com os obtidos por Carson \& Hooker (1981a). A porcentagem da variação fenotípica explicada pelos QRLs foi baixa quando comparada às estimativas de herdabilidade do caráter. Entretanto, devido às dificuldades inerentes aos processos de inoculação e avaliação do caráter, os marcadores moleculares ligados aos QRLs podem ser úteis no melhoramento permitindo a seleção na ausência de doença. Além disso, a identificação destes QRLs 
certamente oferece uma significativa contribuição para o entendimento da resistência de milho à antracnose foliar, podendo levar à identificação de genes e elucidação dos mecanismos envolvidos na expressão da resistência. 


\section{CONCLUSÕES}

1) A análise de modelos de herança mista indicou que a resistência à antracnose foliar em milho é controlada por um gene de efeito maior, em todos os cruzamentos e experimentos, e também por poligenes, em pelo menos um dos experimentos.

2) A ação gênica, tanto do gene de efeito maior como dos poligenes é aditiva e dominante, com predominância dos efeitos genéticos aditivos.

3) Pelo menos um QRL para antracnose foliar foi detectado no cromossomo 10 específico para cada experimento, tanto pela análise de regressão múltipla como pelo mapeamento por intervalo composto. Também foram detectados QRLs nos cromossomos 2, 3 e 5, pela análise de regressão múltipla.

4) Os QRLs identificados pela análise de regressão múltipla explicaram $25,7 \%, 23,3 \%$ e $24,5 \%$ da variação fenotípica no experimento 1 , no experimento 2 e na análise conjunta, respectivamente. Já os QRLs identificados pelo mapeamento por intervalo composto explicaram $28,9 \%, 32,3 \%$ e $31,0 \%$ da variação fenotípica no experimento 1, no experimento 2 e na análise conjunta, respectivamente.

5) A análise de bulks segregantes permitiu a detecção apenas dos QRLs de efeitos fenotípicos mais expressivos, localizados no cromossomo 10.

6) A maioria dos alelos de resistência dos QRLs detectados descenderam do genitor resistente. 


\section{REFERÊNCIAS BIBLIOGRÁFICAS}

AGRAMA, H.A.; MOUSSA, M.E.; NASER, M.E.; TAREK, M.A.; IBRAHIM, A.H. Mapping of QTL for downy mildew resistance in maize. Theoretical and Applied Genetics, v.99, n.3-4, p.519-523, Aug. 1999.

ARNHEIM, N.; STARNGE, C.; ERLICH, H. Use of pooled DNA samples to detect linkage disequilibrium of polymorphic restriction fragments and human disease: studies of the HLA class II loci. Proceedings of the National Academy of Sciences of the United States of America, v.82, n.20, p.6970-6974, 1985.

BADU-APRAKU, B.; GRACEN, V. E.; BERGSTROM, G. C. Inheritance of resistance to anthracnose stalk rot and leaf blight in maize inbred derived from a temperate by tropical germplasm combination. Maydica, v.32, n.3, p.221-237, 1987.

BELL,C.J.; ECKER, J.R. Assignment of 30 microssatellite loci to the linkage map of Arabidopsis. Genome, v.19, p.137-144, 1994.

BENTOLIA, S.; GUITTON, C.; BOUVET, N.; SAILLAND, A.; NYKAZA, S.; FREYSSIENT, G. Identification of an RFLP marker tightly linked to the Ht1 gene in maize. Theoretical and Applied Genetics, v.82, n.4, p.393-398, 1991. 
BERGSTROM, G.C.; NICHOLSON, R.L. The biology of corn anthracnose. Plant Disease, v.83, n.7, p.596-608, Jul. 1999.

BERNARDO, R. Breeding for quantitative traits in plants. Woodbury: Stemma Press, 2002. 369p.

BROWERS, J.E.; DANGI, G.S.; VIGNANI, R.; MEREDITH, C.P. Isolation and characterization of new polymorphic simple sequence repeat loci in grape (Vitis vinifera L.). Genome, v.39, n.4, p.628-633, Aug. 1996.

BROWN, S.M.; SZEWC-MCFADDEN, A.K.; KRESOVICH, S. Development and application of simple sequence repeat (SSR) loci for plant genome analysis. In: JAUHAR, P.P. (Ed.) Methods of genome analysis in plants. Boca Raton: CRC Press, 1996. Cap.9, p.147-159.

BROWN, A.F.; JUVIK, J.A.; PATAKY, J.K. Quantitative trait loci in sweet corn associated with partial resistance to Stewart's wilt, northern corn leaf blight, and common rust. Phytopathology, v.91, n.3, p.293-300, Mar. 2001.

BRUNELLI, K.R.; SILVA, H.P.; CAMARGO, L.E.A. Mapeamento de genes de resistência a Puccinia polysora em milho. Fitopatologia Brasileira, v.27, n.2, p.134-140, 2002.

BUBECK, D.M.; GOODMAN, M.M.; BEAVIS, W.D.; GRANT, D. Quantitative trait loci controlling resistance to gray leaf spot in maize. Crop Science, v.33, n.4, p.838-847, Jul.-Aug. 1993.

CADENA-GOMEZ, G.; NICHOLSON, R.L. Papilla formation and associated peroxidase activity: A non-specific response to attempted fungal penetration 
of maize. Physiological and Molecular Plant Pathology, v.31, n.1, p.5167, Jul. 1987.

CALLAWAY, M.B.; SMITH, M.E.; COFFMAN, W.R. Effect of anthracnose stalk rot on grain yield and related traits of maize adapted to the northeastern United States. Canadian Journal of Plant Science, v.72, n.4, p.1031-1036, Oct. 1992.

CARSON, M. L.; HOOKER, A. L. Inheritance of resistance to anthracnose leaf blight in five inbred lines of corn. Phytopathology, v.71, n.5, p.488-491, 1981a.

CARSON, M. L.; HOOKER, A. L. Inheritance of resistance to stalk rot of corn caused by Colletotrichum graminicola. Phytopathology, v.71, n.11, p.11901196, $1981 b$.

CASELA,C.R.; FERREIRA, A.S. Antracnose do sorgo (Colletotrichum graminicola). Sete Lagoas: EMBRAPA - CNPMS, 1998. 19p. (EMBRAPA CNPMS. Circular Técnica, 28)

CASTIGLIONI, P.; AJMONE-MARSAN, P.; VAN WIJK, R.; MOTTO, M. AFLP markers in a molecular linkage map of maize: codominant scoring and linkage group distribution. Theoretical and Applied Genetics, v.99, n.3-4, p.425-431, Aug. 1999.

CERVERA, M.T.; GUSMÃO, J.; STEENACKERS, M.; PELEMAN, J.; STORME, V.; VANDEN BROECK, A.; VAN MONTAGU, M.; BOERJAN, W. Identification of AFLP molecular markers for resistance against Melampsora 
larici-populina in Populus. Theoretical and Applied Genetics, v.93, n.5-6, p.733-737, Oct. 1996.

CHIN, E.C.L.; SENIOR, M.L.; SMITH, J.S.C. Maize simple repetitive DNA sequences: abundance and allele variation. Genome, v.39, n.5, p.866-873, Oct. 1996.

COELHO, A.S.G. Considerações gerais sobre a análise de QTLs. In: PINHEIRO, J.B.; CARNEIRO, I.F. (Ed.) Análise de QTL no melhoramento de plantas. Goiânia: FUNAPE, 2000. p.1-36.

COÊLHO, R.M.S.; SILVA, H.P.; BRUNELLI, K.R.; CAMARGO, L.E.A. Controle genético da antracnose foliar. Fitopatologia Brasileira, v.26, n.3, p.640643, Set. 2001.

COLLINS, N.; DRAKE, J.; AYLIFFE, M.; SUN, Q.; ELLIS, J.; HULBERT, S.; PRYOR, T. Molecular characterization of the maize rp1-D rust resistance haplotype and its mutants. Plant Cell, v.11, n.7, p.1365-1376, Jul. 1999.

CONDIT, R.; HUBBELL, S. P. Abundance and DNA sequence of two-base repeat regions in tropical tree genomes. Genome, v.34, n.1, p.66-71. Feb. 1991.

DALE, J.L. Corn anthracnose. Plant Disease Reporter, v.47, p.245-249, 1963.

DEMPSTER, A.P.; LAIRD, M.N.; RUBIN, D.B. Maximum likelihood from incomplete data via the EM algorithm. Journal Royal Statistics Society B, v.39, p.1-22, 1977. 
DRAPER, M.R.; SMITH, H. Applied regression analysis. 3.ed. New York: Wiley, 1998. 706p.

DUDLEY, J.W. Molecular markers in plant improvement: manipulation of genes affecting quantitative traits. Crop Science, v.33, p.660-668, 1993.

ELSTON, R.C.; STEWARD, J. The analysis of quantitative traits for simple genetic models from parental, $F_{1}$ and backcross data. Genetics, v.73, n.4, p.695-711, Apr. 1973.

FERNANDES, F.T.; BALMER, E. Situação das doenças de milho no Brasil. Informe Agropecuário, v.14, n.165, p.35-37, 1990.

FERREIRA, M.E.; GRATTAPAGLIA, D. Introdução ao uso de marcadores moleculares em análise genética. 2.ed. Brasília: EMBRAPA-CENARGEM, 1996. 220P.

FORGEY, W.M.; BLANCO, M.H.; LOEGERING, W.Q. Differences in pathological capabilities and host specificity of Colletotrichum graminicola on Zea mays. Plant Disease Reporter, v.62, n.7, p.573-576, 1978.

FREYMARK, P.J.; LEE, M.; MARTINSON, C.A.; WOODMAN, W.L. Molecularmarker-facilitated investigation of host-plant response to Exserohilum turcicum in maize (Zea mays L.): Components of resistance. Theoretical and Applied Genetics, v.88, n.3-4, p.305-313, Jun. 1994.

GAI, J.; WANG, J. Identification and estimation of a QTL model and its effects. Theoretical and Applied Genetics, v.97, n.7, p.1162-1168, Nov. 1998. 
GUPTA, P.K.; BALYAN, H.S.; SHARMA, P.C.; RAMESH, B. Microsatellites in plants: a new class of molecular markers. Current Science, v.70, n.1, p.4554, Jan. 1996.

HALDANE, J.B.S. The combination of linkage values, and calculation of distance between the loci of linked factors. Journal of Genetics, v.8, p.299309, 1919.

HAMMERSCHMIDT, R.; NICHOLSON, R.L. Resistance of maize to anthracnose - effect of light intensity on lesion development. Phytopathology, v.67, n.2, p.247-250, 1977.

HALEY, C.S.; KNOTT, S.A. A simple regression method for mapping quantitative trait loci in line crosses using flanking markers. Heredity, v.69, p.315-324, Oct. 1992.

HOISINGTON, D.; KHAIRALLAH, M.; GONZALEZ DE LEON, D. Laboratory protocols: CIMMYT applied molecular genetics laboratory. 2.ed. México: CIMMYT, 1994. 51p.

HULBERT, S.H.; WEBB, C.A.; SMITH, S.M.; SUN, Q. Resistance gene complexes: evolution and utilization. Annual Review of Phytopathology, v.39, p.285-312, 2001.

JAMIL, F. F.; NILCHOLSON, R. L. Susceptibility of corn to isolates of Colletotrichum graminicola pathogenic to other grasses. Plant Disease, v.71, n.9, p.809-810, Sep. 1987. 
JANSEN, R.C. Interval mapping of multiple quantitative trait loci. Genetics, Bethesda, v.135, n.1, p.205-211, Sep. 1993.

JANSS, L.L.G. THOMPSON, R.; VAN ARDENDONK, J.A.M. Application of Gibbs sampling for inference in a mixed major gene-polygene inheritance model in animal populations. Theoretical and Applied Genetics, v.91, n.67, p.1137-1147, Nov. 1995.

JIANG, C.; PAN, X.; GU, M. The use of mixture models to detect effects of major genes on quantitative characters in plant breeding experiments. Genetics, v.136, n.1, p.383-394, Jan. 1994.

JOHAL, G.S.; BRIGGS, S.P. Reductase activity encoded by the HM1 disease resistance gene in maize. Science, v.258, n.5084, p.985-987, Nov. 1992.

JUNG, M.; WELDEKIDAN, T.; SCHAFF, D.; PATERSON, A.; TINGEY, S.; HAWK, J. Generations-means analysis and quantitative trait locus mapping of anthracnose stalk rot genes in maize. Theoretical and Applied Genetics, v.89, n.4, p.413-418, Oct. 1994.

KAO, C.H.; ZENG, Z.B.; TEASDALE, R.D. Multiple interval mapping of quantitative trait loci. Genetics, v.152, n.3, p.1203-1216, Jul. 1999.

KEIM, P. SCHUPP, J.M.; TRAVIS, S.E.; CLAYTON, K.; ZHU, T.; SHI, L. FERREIRA, A.; WEBB, D.M. A high-density soybean genetic map based on AFLP markers. Crop Science, v.37, n.2, p.537-543, Mar.-Apr. 1997.

KELLER, N.P.; BERGSTROM, G.C. Developmental predisposition of maize to anthracnose stalk rot. Plant Disease, v.72, n.11, p.977-980, Nov. 1988. 
KELlER, N.P.; BeRGSTROM, G.C.; CARRUTHERS, R.I. Potential yield reductions in maize associated with na anthracnose/European corn borer pest complex in New York. Phytopathology, v.76, n.6, p.586-589, Jun. 1986.

KERNS, M.R.; DUDLEY, J.W.; RUFENER, II, G.K. QTL for resistance to common rust and smut in maize. Maydica, n.44, n.1, p.37-45, 1999.

KNOTT, S.A.; HALEY, C.S.; THOMPSON, R. Methods of segregation analysis for animal breeding data: a comparison of power. Heredity, v.68, n.299-311, p.299-311, Apr. 1991.

KOSAMBI, D.D. The estimation of mao distances from recombination values. Annual of Eugenics, v.12, p.172-175, 1944.

KYETERE, D.; MING, R.; McMULLEN, M.D.; PRATT, R.; BREWBAKER, J.; MUSKET, T.; PIXLEY, K.; MOON, H. Monogenic resistance to maize streak virus maps to the short arm of chromosome 1. Maize Genetics Cooperation Newsletter, v.69, p.136-137, 1995.

LANDER, E.S.; BOTSTEIN, D. Mapping mendelian factors underlying quantitative traits using RFLP linkage maps. Genetics, v.121, n.1, p.185199, Jan. 1989.

LANDER, E.S.; GREEN, P.; ABRAHAMSON, J.; BARLOW, A.; DALY, M.J.; LINCOLN, E.E.; NEWBURG, L. Mapmaker: na interactive computer 
package for constructing primary genetic linkage maps of experimental and natural populations. Genomics, v.1, p.174-181, 1987.

LAGERCRANTZ, U.; ELLEGREN, H.; ANDERSSON, L. The abundance of various polymorphic microsatellite motifs differs between plants and vertebrates. Nucleic Acids Research, v.21, n. 5, p.1111-1115, Mar. 1993.

LEHMENSIEK, A.; ESTERHUIZEN, A.M.; VAN STADEN, D.; NELSON, S.W.; RETIEF, A.E. Genetic mapping of gray leaf spot (GLS) resistance genes in maize. Theoretical and Applied Genetics, v.103, n.5, p.797-803, Oct. 2001.

LE ROY, P.; NAVEAU, J.; ELSEN, J.M.; SELLIER, P. Evidence for a new major gene influencing meat quality in pigs. Genetic Research, v.55, p.33-40, 1990.

LIM, S.M.; WHITE, D.G. Estimates of heterosis and combining ability for resistance to Colletotrichum graminicola. Phytopathology, v.68, n.9, p.1336-1342, 1978.

LIU, B.H. Statistical genomics. New York: CRC, 1998. 610p.

LOISEL, P.; GOFFINET, B.; MONOD, H.; DE OCA, G.M. Detecting a major gene in an F2 population. Biometrics, v.50, n.2, p.512-516, Jun. 1994.

LOPES, M.T.G. Mapeamento de genes de resistência a mancha de Phaeosphaeria em milho. Piracicaba, 2003. 117p. Tese (doutorado) - 
Escola Superior de Agricultura "Luiz de Queiroz", Universidade de São Paulo.

LYNCH, M.; WALSH, B. Genetics and analysis of quantitative traits. Sunderland: Sinauer Associates, 1998. 980p.

LYONS, P.C.; HIPSKIND, J.; VINCENT, J.R.; NICHOLSON, R.L. Phenylpropanoid dissemination in maize resistant or susceptible to Helminthosporium maydis. Maydica, v.38, n.3, p.175-181, 1993.

MARQUES, C.M.; ARAÚJO, J.A.; FERREIRA, J.G.; WHETTEN, R.; O'MALLEY, D.M.; LIU, B.H.; SEDEROFF, R. AFLP genetic maps of Eucalyptus globulus and E. tereticorns. Theoretical and Applied Genetics, v.96, n.6-7, p.727737, May 1998.

MATHER, K.; JINKS, J.L. Biometrical Genetics. Ithaca, Cornell University Press, 1971, 382p.

McMULLEN, M.D.; JONES, M.W.; SIMCOX, K.D.; LOUIE, R. Three genetic loci control resistance to wheat streak mosaic virus in the maize inbred Pa405. Molecular Plant-Microbe Interactions, v.7, n.6, p.708-712, Nov./Dec. 1994.

McMULLEN, M.D.; SIMCOX, K.D. Genomic organization of disease and insect resistance genes in maize. Molecular Plant-Microbe Interactions, v.8, n.6, p.811-815, Nov./Dec. 1995.

MEKSEM, K.; LEISTER, D.; PELEMAN, J.; ZABEAU, M.; SALAMINI, F.; GEBHARDT, C. A high resolution map of vicinity of the $R 1$ locus on 
Chromosome $\mathrm{V}$ of potato based on RFLP and AFLP markers. Molecular General Genetics, v.249, n.1, p.74-81, Nov. 1995.

MELO, L.C. Mapeamento de QTLs em feijoeiro, por meio de marcadores RAPD, em diferentes ambientes. Lavras, 2000.148p. Tese (Doutorado) Universidade Federal de Lavras.

MICHELMORE, R.A.; PARAN, I.; KESSELI, R.V. Identification of markers linked to disease resistance genes by bulked segregant analysis: a rapid method to detect markers in specific genomic regions by using segregant populations. Proceedings of the National Academy of Sciences of the United States of America, v.88, n.21, p.9828-9832, Nov. 1991.

MILACH, S.C.K. Marcadores moleculares em plantas. Porto Alegre: UFRGS, 1998. 141p.

MING, R.; BREWBAKER, J.L.; MOON, H.G.; MUSKET, T.; HOLLEY, R.; PATAKY, J.K.; MCMULLEN, M.D. Identification of RFLP markers linked to a major gene, sw1, conferring resistance to stewart's wilt in maize. Maydica, v.44, n.4, p.319-323, 1999.

MING, R.; McMULLEN, M.D.; BREWBAKER, J.L.; PRATT, R.C.; MOON, H.G.; MUSKET, T.; HOLLEY, R. RFLP mapping of genes conferring resistance to Erwinia stewartii. Maize Genetics Cooperation Newsletter, v.69, p.60, 1995a.

MING, R.; McMULLEN, M.D.; BREWBAKER, J.L.; PRATT, R.C.; MOON, H.G.; MUSKET, T.; HOLLEY, R. RFLP mapping of maize mosaic virus resistance genes. Maize Genetics Cooperation Newsletter, v.69, p.60-61, 1995b. 
MOOD, A.M.; GRAYBILL, F.A.; BOES, D.C. Introduction to the theory of statistics. 3. Ed. Tókio: McGraw-Hill Kogakusha, 1974. 564p.

MORCHEN, M.; CUGUEN, J.; MICHAELIS, G.; HANNI, C.; SAUMITOULAPRADE, P. Abundance and length polymorphism of microsatellite repeats in Beta vulgaris L. Theoretical and Applied Genetics, v.92, n.3-4, p.326333, Apr. 1996.

MORELLO, R.M.S.C. Resistência em milho (Zea mays L.) a Colletotrichum graminicola (Ces.) Wils. Piracicaba, 2000. 94p. Tese (Doutorado) - Escola Superior de Agricultura "Luiz de Queiroz", Universidade de São Paulo.

MORTON, M.E.; MACLEAN, C.J. Analysis of family resemblance. III. Complex segregation analysis of quantitative traits. American Journal of Human Genetics, v. 26, n.4, p.489-503, 1974.

MULLIS, K.; FALOONA, F.; SCHARF, S.; SAIKI, R.; HORN, G.; ERILICH, H. Specific enzymatic amplification of DNA in vitro: the polymerase chain reaction. Cold Spring Symposium Quantitative Biology, v.51, p.263-273, 1986.

NAYLOR, D. V.; LEONARD, K. J. Survival of Colletotrichum graminicola graminicola in infected corn stalks in North Carolina. Plant Disease Reporter, v. 61, n. 4, p. 382-383, 1977.

NICHOLSON, R.L.; WARREN, H.L. Criteria for evaluation of resistance to maize anthracnose. Phytopathology, v.66, n.1, p.86-90, 1976. 
NICHOLSON, R.L.; WARREN, H.L. The issue of races of Colletotrichum graminicola pathogenic to corn. Plant Disease, v.65, n.2, p.143-144, 1981.

OGLIARI, J.B. Identificação e localização de um gene de resistência de milho a Exserohilum turcicum (Pass) Leonard \& Suggs através do uso de marcadores moleculares microssatélites. Piracicaba, 1999. 114p. Tese (Doutorado) - Escola Superior de Agricultura "Luiz de Queiroz",de São Paulo.

PATERNIANI, M.E.A.G.Z.; SAWAZAKI, E.; DUDIENAS, C.; DUARTE, A.P.; GALLO, P.B. Diallel crosses among maize lines with emphasis on resistance to foliar diseases. Genetics and Molecular Biology, v.23, n.2, p.381-385, Jun. 2000.

PE, M.E.; GIANFRANCESCHI, L.; TARAMINO, G.; TARCHINI, R.; ANGELINI, P.; DANI, M.; BINELLI, G. Mapping quantitative trait loci (QTL) for resistance to Gibberella zeae infection in maize. Molecular General Genetics, v.241, n.1-2, p.11-16, Oct. 1993.

PERKINS, J.M.; HOOKER, A.L. The effects of anthracnose stalk rot on corn yields in Illinois. Plant Disease Reporter, v.63, n.1, p.26-30, 1979.

PERNET, A.; HOISINGTON, D.; DINTINGER, J.; JEWELL, D.; JIANG, C.; KHAIRALLAH, M.; LETOURMY, P.; MARCHAND, J.L.; GLASZMANN, J.C.; GONZÁLEZ DE LEÓN. Genetic mapping of maize streak virus resistance from the Mascarene source. II. Resistance in line CIRAD390 and stability across germplasm. Theoretical and Applied Genetics, v.99, n.3-4, p.540553, Aug. 1999. 
PONTES, M.F.C. Características fisiológicas e morfológicas de Colletotrichum graminicola (Ces.) Wils. e avaliação de fontes de resistência em milho (Zea mays L.). Recife, 1987. 82p. Dissertação (M.S.) - Universidade Federal Rural de Pernambuco.

QI, X.; STAM, P.; LINDHOUT, P. Use of locus-specific AFLP markers to construct a high-density molecular map in barley. Theoretical and Applied Genetics, v.96, n.3-4, p.376-384, Mar. 1998.

RONGWEN, J.; CREGAN, P.B.; AKKAYA, M.S.; BHAGWAT, A.A.; LAVI, U. The use of simple sequence repeat DNA markers for soybean genotype identification. Theoretical and Applied Genetics, v.90, n.1, p.43-48, Jan. 1995.

SAGHAI-MAROOF, M.; BIYASHEV, R.M.; YANG, G.P.; ZHANG, Q.; ALLARD, R.W. Extraordinarily polymorfic microssatellite DNA in Barley: species diversity, cromossomal locations, and population dynamics. Proceedings of the National Academy of Sciences of the United States of America, v.91, n.12, p.5466-5470, Jun. 1994.

SCHALL, R.A.; NICHOLSON, R.L.; WARREN, H.L. Influence of light on maize anthracnose in the greenhouse. Phytopathology, v.70, n.10, p.1023-1026, 1980.

SENIOR, M.L.; CHIN, E.C.L.; LEE,M.; SMITH, J.S.C.; STUBER, C.W. Simple sequence repeat markers developed from maize sequences found in the GENBANK database: map construction. Crop Science, v.36, n.6, p.16761683, Nov./Dec. 1996. 
SHOUKRI, M.M.; MCLACHLAN, G.J. Parametric estimation in a genetic mixture model with application to nuclear family data. Biometrics, v.50, n.1, p.128139, Mar. 1994.

SHURTLEFF, M. C. (Ed.). A compendium of corn disease. St Paul: APS,.1980.64p.

SILVA, W.P. Estimadores de máxima verossimilhnça em misturas de densidades normais: uma aplicação em genética. Lavras, 2003. 60p. Dissertação (Mestrado) - Universidade Federal de Lavras.

SILVA, H.D.; VENCOVSKY, R. Poder de detecção de "Quantitative Trait Loci" da análise de marcas simples e da regressao linear múltipla. Scientia Agricola, v.59, n.4, p.755-762, Dez. 2002.

SILVA, H. P.; PEREIRA, O. A. P.; MIRANDA FILHO, J. B.; BALMER, E. Herança da resistência à antracnose foliar Colletotrichum graminicola (Ces.)Wils. em milho. Fitopatologia Brasileira, v.11, n.3, p.617-626, 1986.

SILVEIRA, A. P. da; BARRETO, M. F.; CRUZ, B. P. Ocorrência de antracnose do milho no Estado de São Paulo. O Biológico, v.31, p.192-194, 1965.

SIMCOX, K.D.; BENNETZEN, J.L. The use of molecular markers to study Setosphaeria turcica resistance in maize. Phytopathology, v.83, n.12, p.1326-1330, Dec. 1993.

SIMCOX, K.D.; McMULLEN, M.D.; LOUISE, R. Co-segregation of the maize dwarf mosaic virus resistance gene, $m d m 1$, with the nucleolus organiser 
region in maize. Theoretical and Applied Genetics, v.90, n.3-4, p.341346, Mar. 1995.

SKOROPAD, W.P. Effect of temperature on the ability of Colletotrichum graminicola to form apressoria and penetrate barley leaves. Canadian Journal of Plant Science, v.47, p.431-434, 1967.

SMITH, D.R. Yield reduction in dent corn caused by Colletotrichum graminicola. Plant Disease Reporter, v.60, n.11, p.967, 970, 1976.

SMITH, J. S. C.; CHIN, E. C. L.; SHU, H.; SMITH, O. S.; WALL, S. J.; SENIOR, M. L.; MITCHELL, S. E.; KRESOVICH, S.; ZIEGLE, J. An evaluation of the utility of SSR loci as molecular markers in Maize (Zea mays L.): comparisons with data from RFLPs and pedigree. Theoretical and applied Genetics, v.95, n.1-2, p.163-173. Jul. 1997.

SUN, Q.; COLLINS, N.C.; AYLIFFE, M.; SMITH, S.M.; DRAKE, J.; PRYOR, T.; HULBERT, S.H. Recombination between paralogues at the rp1 rust resistance locus in maize. Genetics, v.158, n.1, p.423-438, May, 2000.

TANKSLEY, S.D. Mapping polygenes. Annual Review of Genetics, v.27, p.205-233, 1993.

TAUTZ, D. Hypervariability of simple sequences as a general source for polymorphic DNA markers. Nucleic Acids Research, v.17, n.16, p.64636471, Aug. 1989. 
TAUTZ, D.; TRICK, M.; DOVER, G.A. Cryptic simplicity in DNA is a major source of genetic variation. Nature, v.322, p.6080, p.652-656, Aug. 1986.

THOMAS, C.M.; VOS, P.; ZABEAU, M.; JONES, D.A.; NORCOTT, K.A.; CHADWICK, B.P.; JONES, J.D.G. Identification of amplified restriction fragment polymorphism (AFLP) markers tightly linked to the tomato Cf-9 gene for resistance to Cladosporium fulvum. Plant Journal, v.8, n.5, p.785794, Nov. 1995.

TOMAN, J.; WHITE, D. J. Inheritance of resistance to stalk rot of corn. Phytopathology, v.83, n.9, p.981-986, Sep. 1993.

TOURJEE, K.R.; HARDING, J.; BYRNE, T.G. Complex segregation analysis of Gerbera flower color. Heredity, v.74, p.303-310, Mar. 1995.

VAN ECK, H.J.; VAN DER VOORT, J.R.; DRAAISTRA, J.R.; VAN, ZANDVOORT, P.; VAN ENCKEVORT, E.; SEGERS, B.; PELEMAN, J.; JACOBSEN, E.; HELDER, J.; BAKKER, J. The inheritance of chromosomal localization of AFLP markers in a non-inbred potato offspring. Molecular Breeding, v.1, n.4, p.397-410, 1995.

VENCOVSKY, R.; BARRIGA, P. Genética biométrica no fitomelhoramento. Ribeirão Preto: SBG, 1992. 486p.

VOS, P.; HOGERS, R.; BLEEKER, M.; REIJANS, M.; VAN DE LEE, T.; HORNERS, M.; FRIJTERS, A.; PLOT, J.; PELEMAN, J.; KUIPER, M.; 
ZABEAU, M. AFLP: a new technique for DNA fingerprinting. Nucleic Acids Research, v.23, n.21, p.4407-4414, Nov. 1995.

VOS, P.; SIMONS, G.; JESSE, T.; WIJBRANDI, J.; HEINEN, L.; HOGERS, R.; FRIJTERS, A.; GROENENDIJKI, J.; DIERGAARDE, P.; REIJANS, M.; FIERENS-ONSTENK, J.; DE BOTH, M.; PELEMAN, J.; LIHARSKA, T.; HONTELEZ, J.; ZABEAU, M. The tomato Mi-1 gene confers resistance to both root-knot nematodes and potato aphids. Nature Biotechnology, v.16, n.13, p.1365-1369, Dec. 1998.

VUYLSTEKE, M.; MANK, R.; ANTONISE, R.; BASTIANS, E.; SENIOR, M.L.; STUBER, C.W.; MELCHINGER, A.E.; LÜBBERSTEDT, T.; XIA, X.C.; STAM, P.; ZABEAU, M.; KUIPER, M. Two high-density AFLP® linkage maps of Zea mays L.: analysis of distribution of AFLP markers. Theoretical and Applied Genetics, v.99, n.6, p.921-935, Oct. 1999.

WANG, J.; GAI, J. Mixed inheritance model for resistance to agromyzed beanfly (Melanagromyza sojae Zehntner) in soybean. Euphytica, v.122, n.1, p.918, 2001.

WARREN, H. L. Survival of Colletotrichum graminicola in corn kernels. Phytopathology, v.67, n.2, p.160-162, 1977.

WARREN, H. L.; NICHOLSON, R. L.; ULLSTRUP, A. J.; SHERVELLE, E. J. Observations of Colletotrichum graminicola to foliar and kernels infection. Plant Disease Reporter, v.57, n.2, p.143-144, 1973.

WELZ, H.G.; XIA, X.C.; BASSETTI, P.; MELCHINGER, A.E.; LÜBBERSTEDT, T. QTLs for resistance to Setosphaeria turcica in na early maturing Dent $x$ 
Flint maize population. Theoretical and Applied Genetics, v.99, n.3-4, p.649-655, Aug. 1999.

WHITE, D.G.; YANNEY, J.; ANDERSON, B. Variation in pathogenicity, virulence, and aggressiveness of Colletotrichum graminicola on corn. Phytopathology, v.77, n.7, p.999-1001, Jul. 1987.

WU, K.S.; TANKSLEY, S.D. Abundance, polymorphism and genetic mapping of microsatellites in rice. Molecular General Genetics, v.241, n.1-2, p.225235, Oct. 1993.

XU, M.L.; MELCHINGER, A.E.; XIA, X.C.; LUBBERSTEDT, T. Hight-resolution mapping of loci conferring resistance to sugarcane mosaic virus in maize using RFLP, SSR and AFLP markers. Molecular and General Genetics, v.261, n.3, p.574-581, Apr. 1999.

ZAITLIN, D.; DEMARKS, S.; GUPTA, M. Linkage of a second gene for NCLB resistance to molecular markers in maize. Maize Genetics Cooperation Newsletter, v.66, p.69-70, 1992.

ZAITLIN, D.; DEMARKS, S.; GUPTA, M. Linkage of $h r m$, a recessive gene for resistance to southern corn leaf blight, to RFLP marker loci in maize (Zea mays) seedlings. Genome, v.36, n. 3, p.555-564, Jun. 1993.

ZENG, Z.B. Precision mapping of quantitative trait loci. Genetics, v.136, n.9, p.1457-1468, 1994. 
ZENG, Z.B. Theoretical basis for separation of multiple linked gene effect in mapping quantitative trait loci. Proceedings of the National Academy of Sciences USA, v.90, p.10972-10976, 1993.

ZHU, J.; GALE, M.D.; QUARRIE, S.; JACKSON, M.T.; BRYAN, G.J. AFLP markers for the study of rice diversity. Theoretical and Applied Genetics, v.96, n.5, p.602-611, Apr. 1998.

ZUBER, M.S.; AINSWORTH, T.C.; BLANCO, M.H.; DARRAH, L.L. Effect of anthracnose leaf blight on stalk rind strength and yield in $F_{1}$ single crosses in maize. Plant disease, v.65, n.9, p.719-722, 1981. 